\title{
BEYOND ECONOMIC FATHERHOOD: ENCOURAGING DIVORCED FATHERS TO PARENT
}

\author{
SOLANGEL MALDONADO ${ }^{\dagger}$
}

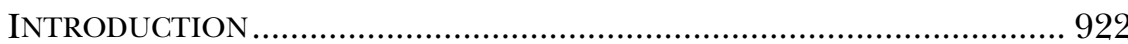

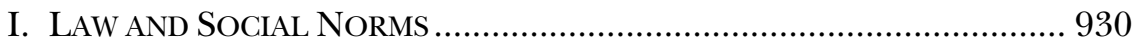

II. CURRENT NORMS OF POST-DIVORCE FATHERHOOD......................... 938

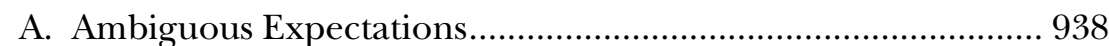

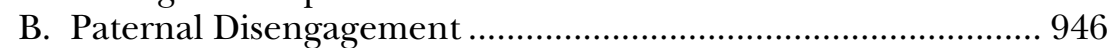

C. Paternal Involvement and Children's Development................. 949

1. Educational and Societal Benefits ............................................ 951

2. Emotional and Psychological Benefits ................................ 957

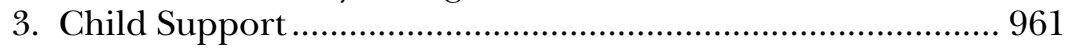

III. REASONS FOR PATERNAL DISENGAGEMENT …................................ 962

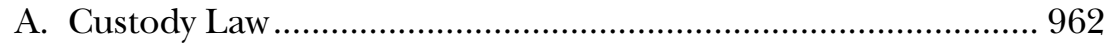

B. Gender Bias: Reality or Perception? ...................................... 967

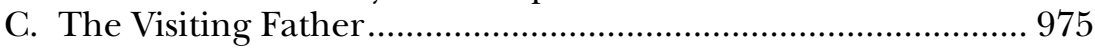

1. Vanilla Visitation and Disneyland Daddies ............................ 976

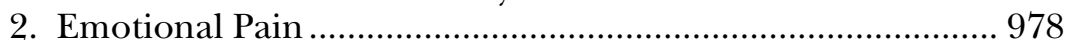

3. Conflict With the Child's Mother ........................................... 979

IV. Changing The Norm: Encouraging PATERnAL

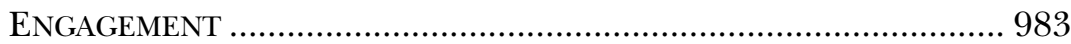

A. Presumption of Joint Legal Custody...................................... 984

1. Symbolic Function and Paternal Involvement ....................... 990

2. Why Not Joint Physical Custody? .......................................... 997

B. Creating a Norm of Nurturing Fatherhood ............................. 1000

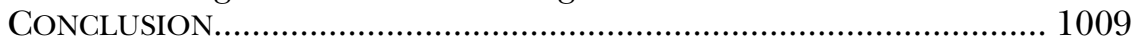

\footnotetext{
${ }^{\dagger}$ Associate Professor, Seton Hall University School of Law. J.D., Columbia Law School, 1996. This Article was presented at the Symposium on Alternative Families at RutgersNewark Law School and at the Northeast People of Color Legal Scholarship Conference at the University of Connecticut School of Law. I am deeply grateful to the participants at both conferences for their helpful comments. The Article also benefited from my participation in the Seton Hall Summer Brown Bag Lunch Series and the comments of my colleagues who attended. In addition, I thank Carlos Bellido, Carl Coleman, Tristin Green, Rachel Godsil, Kevin Kelly, Charlie Sullivan, and Sarah Waldeck for their suggestions on earlier drafts. Thanks to Susie Cho, Brian Ford, Jody Walker, and the Seton Hall library staff for valuable research assistance. The Article was made possible by the generous support of the Seton Hall University School of Law Summer Research Stipend Program.
} 


\section{INTRODUCTION}

"[F] atherhood is in vogue." Married fathers are dedicating more time to their children than ever before. ${ }^{2}$ As a result of mothers' increasing presence in the workforce and a developing cultural emphasis on fathers as nurturers, ${ }^{3}$ married fathers are assuming a larger share of child-rearing responsibilities than their own fathers ever did. ${ }^{4}$ The mass media has embraced this nurturing and emotionally attuned "modern father" - a sharp departure from the traditional father of the 1950 s, whose role was primarily that of breadwinner and authority figure. These new generation fathers are present in the delivery room when their children are born, ${ }^{6}$ change diapers, ${ }^{7}$ take paternity leave, ${ }^{8}$

${ }^{1}$ Frank F. Furstenberg, Jr., Good Dads-Bad Dads: Two Faces of Fatherhood, in THE Changing American family and Public Policy 193, 193 (Andrew J. Cherlin ed., 1988).

${ }^{2}$ Susan Steinman, Joint Custody: What We Know, What We Have Yet to Learn, and the Judicial and Legislative Implications, 16 U.C. DAVIS L. REV. 739, 740 (1983).

${ }^{3}$ See David Popenoe, Life Without Father 1 (1996) (noting that Americans expect fathers today to be more involved with their children than fathers in past generations); Jerry Adler, Building A Better Dad, NewsweEk, June 17, 1996, at 58, 59 ("Men today 'have permission to care for their children that they didn't have a generation ago' ...." (quoting Betty Thomson of the Center for Demography and Ecology at the University of Wisconsin)).

${ }^{4}$ See Frank F. Furstenberg, Jr., Fathering in the Inner City: Paternal Participation and Public Policy, in FATHerhood: Contemporary Theory, RESEARCH, AND SOCIAL POLICY 119, 121 (William Marsiglio ed., 1995) ("[T]he segment of highly dedicated dads seems to be growing...."); Adler, supra note 3, at 61 ("A Newsweek poll found that seven out of 10 American fathers spend more time with their children than their own fathers did; nearly half think they are doing a better job ....").

${ }^{5}$ See Furstenberg, supra note 1, at 193 (noting that Bill Cosby is the prototypical modern father: a full partner in parenting). In the 1980s, bookstores were bombarded with titles aimed at these modern fathers, such as How to Father, Expectant Father, Pregnant Fathers, The Birth of a Father, Fathers Almanac, Father Power, How to Father a Successful Daughter, and, of course, Bill Cosby's Fatherhood, "one of the best-selling books in publishing history.” Nancy R. Gibbs, Bringing Up Father, Time, June 28, 1993, at 53, 58; see also Scott Coltrane, The Future of Fatherhood: Social, Demographic, and Economic Influences on Men's Family Involvements, in FATHERHOOD: CONTEMPORARY THEORY, RESEARCH, AND Social POLICY, supra note 4, at 255, 256 ("Starting in the 1970s, films like Kramer vs. Kramer, Mr. Mom, Three Men and a Baby, and Mrs. Doubtfire began celebrating men's love for children, even if the men were initially shown as comically inept. Similarly, television comedies like Full House and Who's the Boss[ ?] began to show men as loving parents and relatively competent housekeepers."). One Fine Day (Twentieth Century Fox 1996) (depicting a single male parent), Two and a Half Men (CBS television series, 2003-current) (featuring divorced fathers), The Bernie Mac Show (Fox television series, 2001-current) (depicting spouses participating equally in parenting), and The Cosby Show (NBC television series, 1984-1992) (same) may also be attributed to this trend. 
prepare their children's meals, and take time off from work to take them to the doctor and nurse them back to health. They attend parent-teacher meetings, school plays, and soccer/basketball/Little League games, and they know the names of their children's teachers and playmates. A small but increasing number of these modern fathers place child-rearing responsibilities above career advancementseeking employment with flexible or reduced schedules-so they can dedicate more time to their children. ${ }^{9}$ A few have even exited the workplace completely to assume primary responsibility for their children's care, while their wives assume the traditionally male role of economic provider. ${ }^{10}$ In short, modern fathers-although still rela-

\footnotetext{
${ }^{6}$ See Gibbs, supra note 5, at 58 (noting that "90\% percent of fathers are in attendance at their child's birth"). This is in contrast to the pre-1970 norm where hospitals did not allow fathers in the delivery room, and some fathers were not even in the vicinity. See, e.g., Adler, supra note 3, at 60 (relating the story of a man who went to work while his child was being delivered because "[b]ack then [32 years ago], the next day was soon enough for a new father to visit his son").

${ }^{7}$ Today, fathers can enroll in courses that teach them "how to change, feed, hold and generally take care of" a baby. Gibbs, supra note 5, at 61 . Indeed, some public men's bathrooms now have diaper changing stations. Id.

${ }^{8}$ See Janet Shibley Hyde et al., Fathers and Parental Leave: Attitudes and Experiences, 14 J. FAM. IsSUES 616, 629 (1993) (finding that fathers take on an average five days of parental leave). A January 1993 survey by DuPont found that $5 \%$ of its employees who participated in its family leave program were men. See DuPont Employees Highly Satisfied with Leave Policy, Company's Study Finds, DAILY LAB. ReP. (BNA), Jan. 25, 1993, at A-14 (cited in Robing R. Cockey \& Deborah A. Jeon, The Family Medical Leave Act at Work: Getting Employers to Value Families, 4 VA. J. SOC. POL'y 225, 229 n.20 (1996)); see also Gibbs, supra note 5, at 55 (reporting that $7 \%$ of male employees at Eastman Kodak took family leave in 1993).

9 See Keith H. Hammonds, The Daddy Trap, Bus. WK., Sept. 21, 1998, at 56, 56-64 (discussing nontraditional work arrangements); GALLUP ORG., 1996 GALLUP POLL ON FATHERING: "FATHERS IN AMERICA," (finding that most men believe that their "employer recognizes the strain" caused by work and family demands), available at http://www.fact.on.ca/rel_supp/gallup.htm (last visited Jan. 30, 2005). See generally James A. LEVINE \& TODD L. PITTINSKY, WORKING FATHERS: NEW STRATEGIES FOR BALANCING WORK AND FAMILY (1997) (finding that many men experience conflict balancing work and family life and seek flexible schedules).

${ }^{10}$ Approximately two million fathers are primary caregivers for their children and working wives. Buzz McClain, Please Give the 'Mr. Mom'Stereotype a Timeout-Again, FORT WORTH STAR-TELEGRAM, May 18, 2003, available at http://www.dfw.com/mld/ startelegram/living/5875857.htm?1c. Although few fathers actually leave the workplace, many express a willingness to do so. See Michael Segell, The American Man in Transition, AM. HEALTH, Jan. 1989, at 59-60 (discussing a survey which showed that " $51 \%$ of fathers polled would quit their jobs and stay home with their children if money were not a problem").
} 
tively unusual ${ }^{11}$ - are assuming many of the child-rearing tasks traditionally performed by mothers.

When one compares this new generation of married fathers to divorced fathers, however, the contrast is rather bleak. There are approximately 1.1 million divorces in the United States each year. ${ }^{12}$ About half of these divorcing couples have minor children, resulting in approximately one million children each year experiencing their parents' separation or divorce. ${ }^{13}$ Within three years of divorce, fifty percent of fathers have either ceased contact with their children or see them quite infrequently. ${ }^{14}$ The irony of married fathers becoming

${ }^{11}$ The modern father is by no means the norm. Many married fathers are not involved in their children's day-to-day care. See Popenoe, supra note 3, at 19 (noting that although the overall number of nurturing fathers has increased, their numbers remain quite low); Furstenberg, supra note 4, at 120-21 (noting that most fathers in intact families have traditionally spent little time directly participating in child care or interacting with their children); Alan J. Hawkins \& David J. Eggebeen, Are Fathers Fungible? Patterns of Coresident Adult Men in Maritally Disrupted Families and Young Children's Wellbeing, 53 J. MARRIAGE \& FAM. 958, 959 (1991) (noting that "most fathers are minimally involved with their children even when they live with them"). Further, women today are still doing twice as much work caring for their children as men. Adler, supra note 3, at 61 (citing James A. Levine, director of the Fatherhood Project of the Families and Work Institute).

${ }^{12}$ See Nat'l Ctr. for Health Statistics, U.S. Dep't of Health \& Human Servs., Births, Marriages, Divorces, and Deaths: Provisional Data for September 2001, NAT'L VITAL STAT. REP., May 24, 2002, at 1 (determining this figure based on a rate of 4.0 divorces (including annulments) per 1,000 individuals during the twelve months ending September 2001), available at http://www.cdc.gov/nchs/data/nvsr/nvsr50/nvsr50_08.pdf. Although the Department of Health and Human Services's statistics do not separate divorces from annulments, the latter tend to be rare. Louanne S. Love, The Way We Were: Reinstatement of Alimony After Annulment of Spouse's "Remarriage," 28 J. FAM. L. 289, 292 (1989-1990).

The divorce rate in the United States has increased dramatically since the 1960s. Although it has stabilized and even dropped since the 1980s, see ARTHUR J. NORTON \& LOUisa F. Miller, U.S. DeP'T OF COMMERCE, Pub. No. P23-180, Marriage, DivorCe, AND REMARRIAGE IN THE 1990S 1 (1992), as of 2001, the divorce rate was still fortyseven percent, see Nat'l Ctr. for Health Statistics, supra.

${ }_{13}$ Barbara Dafoe Whitehead, Dan Quayle Was Right, Atlantic Monthly, Apr. 1993, at 47, 50 ("Each year a million children go through divorce or separation . ..."). "When couples with children separate, they face a period of months or even years during which the terms of their legal divorce will be worked out and a custody decree issued.” ElEanor E. MAccoby \& Robert H. MnOokin, Dividing THE CHILd: Social AND LEGAL DilemMAS OF CuSTODY 71 (1992). Because "the transition period from ... separation to about six months to one year afterward is most critical in establishing" paternal involvement, for purposes of this Article, "divorce" refers to the final separation, not the legal divorce decree. Edward Kruk, The Disengaged Noncustodial Father: Implications for Social Work Practice with the Divorced Family, 39 SOC. WORK 15, 16 (1994).

${ }^{14}$ See infra notes 123-27 and accompanying text (discussing fathers' post-divorce contact with their children). 
more involved parents as an almost equal number of men become "absent fathers" $"$ has not been lost on commentators, who note that "[m]en today are better fathers when they're around-and worse when they're not."16 For many children, their parents' divorce is the beginning of their fathers' gradual divorce from them. ${ }^{17}$ Why do so many divorced fathers disengage from their children ${ }^{18}$ Are children worse off when their fathers disappear from their lives? Some studies, many commentators, and most Americans, believe so.

Absent fathers are frequently blamed for many of their children's social, emotional, and behavioral problems. Commentators have argued that children who grow up without fathers are more likely than children who grow up in marital families with both of their biological parents to use drugs, perform poorly in school, drop out of high school, become teen parents, be idle (out of work and school), engage in antisocial or criminal activity, get divorced themselves, or commit or attempt suicide. ${ }^{19}$ These commentators further assert that fathers are essential to children's emotional and mental development, and they propose that the law should encourage parents to stay to-

\footnotetext{
${ }^{15}$ Scholars often utilize the frequency and quality of contact within a one-year period to define an "absent parent." See Frank F. Furstenberg, Jr. et al., The Life Course of Children of Divorce: Marital Disruption and Parental Contact, 48 AM. Soc. Rev. 656, 663 (1983) (noting that " $[\mathrm{m}]$ ost outside parents had seen their child rarely or not at all in the previous year"); Christine Winquist Nord \& Nicholas Zill, Dep't of Health \& Human Servs., Non-Custodial Parents' Participation in Their Children's Lives: Evidence from the Survey of Income and Program Participation (Aug. 14, 1996), at http://fatherhood.hhs.gov/SIPP/noncusp1.htm (last visited Jan. 30, 2005) (showing that $31.7 \%$ of fathers in its 1990 study had failed to spend time with their children in the previous 12 months).

${ }^{16}$ Adler, supra note 3, at 61 (internal quotations omitted) (quoting sociologist Andrew Cherlin); see also Coltrane, supra note 5, at 257 (noting the increase in these polar extremes: highly involved fathers and absent fathers).

${ }^{17}$ See Frank F. Furstenberg, Jr. \& Christine Winquist Nord, Parenting Apart: Patterns of Childrearing After Marital Disruption, 47 J. MARRIAGE \& FAM. 893, 896 (1985) (concluding that, in the majority of cases, marital disruption effectively destroys the relationship between children and their noncustodial fathers).

${ }^{18}$ Although living apart from their children may make it difficult for parents to remain involved in their children's upbringing, unlike fathers, mothers who live apart from their children after divorce often maintain significant contact with them. See Irene M. Cohen, Post Decree Litigation: Is Joint Custody to Blame?, 36 FAM. \& CONCILIATION CTS. REV. 41, 44 (1998) (discussing a 1983 study finding that $86 \%$ of noncustodial mothers had seen their children in the past year and one-third saw their children at least weekly); Furstenberg et al., supra note 15, at 663 (finding that $69 \%$ of noncustodial mothers see their children at least monthly, as compared to $33 \%$ of noncustodial fathers).

${ }^{19}$ See infra Part II.C.1 (discussing the educational and social benefits of parental involvement).
} 
gether-for example, by abolishing no-fault divorce. ${ }^{20}$ If parents stayed together, they posit, many of society's problems could be solved. ${ }^{21}$

Child development experts and social scientists, however, debate whether the absence of a father is a significant cause of these negative outcomes. In contrast to the studies relied upon by fathers' advocates, some studies have found no correlation between paternal involvement and children's well-being. ${ }^{22}$ When studies have found a positive correlation between paternal absence and an increased risk of behavioral, mental, and social problems among children, some commentators have argued that such correlation results from fathers' failure to pay child support, not father absence per se. They point to the substantial decrease in residential mothers' and children's standard of living after divorce as the cause of children's emotional and behavioral problems. ${ }^{23}$ In other words, fathers are not essential to children, but economic support is. Accordingly, these scholars advocate stronger en-

${ }^{20}$ See SANFORd BRAVER, Divorced DADS: SHATtering THE MYTHS 241-44 (1998) (advocating the repeal of no-fault divorce); POPENOE, supra note 3, at 222-23 (proposing a two-tier system of divorce law that would make dissolving marriages with children more difficult).

${ }^{21}$ Forcing parents to stay together for the sake of the children is problematic for many reasons. First, a two-parent high conflict home is not necessarily better for children than a single-parent peaceful home. See Patrick C. McKenry et al., Predictors of Single, Noncustodial Fathers' Physical Involvement with Their Children, 153 J. GENETIC PSYCHOL. 305, 307 (1992) (discussing post-divorce relationships); JUDITH S. WALLERSTEIN \& JOAN BERLIN KELly, SURVIVING THE BREAKUP: HOW CHILDREN AND PARENTS COPE WITH DIVORCE 218 (1980) (discussing positive results in happy, singleparent homes). Second, although obtaining a divorce was difficult during the fault era, couples typically found ways around the law, for example, by divorcing in foreign countries or in sister states with laxer requirements, or simply by living apart for the rest of their lives. E.g., Clagett v. King, 308 A.2d 245, 246 (D.C. 1973) (considering the validity of a divorce decree obtained in Mexico); Fink v. Fink, 346 N.E.2d 415 (Ill. App. 1976) (dealing with a divorce decree obtained in Nevada by an Illinois resident); Peter Nash Swisher, Reassessing Fault Factors in No-Fault Divorce, 31 FAM. L.Q. 269, 270-71 (1997) (discussing divorces obtained on the basis of fabricated faults). In short, even during the fault era, parents who wanted to separate generally did so.

${ }^{22}$ See Martha Albertson Fineman, The Neutered Mother, The Sexual Family AND OTHER TwENTIETH CENTURY TRAgEDies 105 (1995) ("[T]here are studies that find no effect on children's mental health from father absence."). But see infra Part II.C (discussing the effect of paternal involvement on children's development).

${ }^{23}$ Children living with a single mother are six times more likely to be poor than children living with two parents. See Bureau of the Census, U.S. DeP'T OF COMmerce, 1997 Population Profile OF THE UNITED States, 41 fig.18-2 (1998) (showing that the poverty rate was $32.4 \%$ for female householder families with no husband present and $5.6 \%$ for married couple families); see also FrANK F. FURSTENBERG, JR. \& ANDREW J. Cherlin, Divided Families: What HapPens to CHILdREN WHEN PARENTS PART 45 (1991) ("Divorce often results in a sharp drop in the standard of living of children and their custodial parents."). 
forcement of child support awards and governmental support of children and mothers to prevent poverty after divorce.

Even if it is true that what matters is economic support and not paternal involvement per se, absent fathers are still a cause for concern because fathers who maintain significant contact with their children after divorce are more likely to pay child support than fathers who do not maintain contact. ${ }^{24}$ Children whose fathers pay child support generally experience fewer emotional and behavioral problems than children whose fathers do not. ${ }^{25}$ Although the federal and state governments spend billions of dollars each year to enforce child support awards, their efforts have been only marginally successful. ${ }^{26}$ Thus, society and the government may wish to consider encouraging paternal involvement as it may lead to the payment of child support.

Children consistently report that they wish they had more contact with their fathers and that they feel abandoned when their fathers are not involved in their lives. ${ }^{27}$ Thus, independent of any correlation between paternal disengagement and children's educational, social, and behavioral development, children's emotional well-being in and of itself may be sufficient reason to encourage paternal contact. Unfortunately, because society and the law have traditionally treated fathers as primarily economic providers, paternal disengagement has not been perceived as a cause for alarm. Indeed, paternal absence following divorce has been accepted as almost normal. In light of the evidence suggesting that paternal disengagement is harmful to children, I argue that it is crucial that fathers not abandon their children after divorce.

${ }^{24}$ See infra notes 196-97 and accompanying text (comparing the child support payment rate of fathers who maintain some contact with their children with that of uninvolved fathers).

${ }^{25}$ See Douglas B. Downey, The School Performance of Children from Single-Mother and Single-Father Families: Economic or Interpersonal Deprivation?, 15 J. FAM. IssuES 129, 132 (1994) (describing studies finding that "the father's financial support was related to lower problem behavior among children”); Frank F. Furstenberg, Jr. et al., Paternal Participation and Children's Well-Being After Marital Dissolution, 52 AM. Soc. REV. 695, 698-99 (1987) (comparing the effects of different levels of paternal support payments on children's well-being).

${ }^{26}$ In some states the total collection rate is less than ten percent. JANE KNITZER \& Stanley Bernard, NAT'l CTR. FOr Children in Poverty, MaP AND Track: State INITIATIVES TO ENCOURAGE RESPONSIBLE FATHERHOOD app. C at 162 tbl.6 (1997).

${ }^{27}$ See infra notes 169-77 (examining children's feelings regarding absent fathers). 
In recent years, legal scholars have produced a significant body of scholarship devoted to the law's effect on social norms. ${ }^{28}$ Norms theorists have argued that the law can and does influence social norms of marriage and divorce, ${ }^{29}$ parenting, ${ }^{30}$ sex and race discrimination ${ }^{31}$ and even norms of smoking, littering, recycling, and cleaning up after our dogs. ${ }^{32}$ This Article uses social norms theory to explore how the law may have contributed to fathers' disengagement after divorce, and how it can and should facilitate a norm of involved fatherhood,

${ }^{28}$ For a sampling of these works, see generally Lisa Bernstein, Opting Out of the Legal System: Extralegal Contractual Relations in the Diamond Industry, 21 J. LEGAL STUD. 115 (1992); Ann E. Carlson, Recycling Norms, 89 CAL. L. REV. 1231 (2001); Robert D. Cooter, Structural Adjudication and the New Law Merchant: A Model of Decentralized Law, 14 InT'L Rev. L. \& ECON. 215 (1994); Melvin A. Eisenberg, Corporate Law and Social Norms, 99 Colum. L. REv. 1253 (1999); Christine Jolls et al., A Behavioral Approach to Law and Economics, 50 STAn. L. Rev. 1471 (1998); Dan M. Kahan, What Do Alternative Sanctions Mean?, 63 U. CHI. L. REV. 591 (1996); Eric A. Posner, Law and Social Norms: The Case of Tax Compliance, 86 VA. L. REv. 1781 (2000). Numerous journals have also devoted symposia to law and social norms. Symposium, Law, Economics E Norms, 144 U. PA. L. ReV. 1643 (1996); Symposium, Social Norms, Social Meaning, and the Economic Analysis of Law, 27 J. LEgAL STUD. 537 (1998); Symposium, The Legal Construction of Norms, 86 VA. L. REV. 1577 (2000); Symposium, The Legal Implications of Psychology: Human Behavior, Behavioral Economics, and the Law, 51 VAND. L. REV. 1495 (1998).

${ }^{29}$ See, e.g., Elizabeth S. Scott, Social Norms and the Legal Regulation of Marriage, 86 VA. L. REV. 1901, 1954 (2000) (arguing that contemporary divorce law has, at least indirectly, contributed to a weakening of spousal commitment norms).

${ }^{30}$ See, e.g., id. at 1948-49 (presenting an analysis of "the impact of child support statutes on parental norms"); see also Richard H. McAdams, The Origin, Development, and Regulation of Norms, 96 MICH. L. REV. 338, 407-08 (1997) (describing the potential impact on parental norms of laws imposing child safety regulations); David D. Meyer, Family Ties: Solving the Constitutional Dilemma of the Faultless Father, 41 ARIZ. L REV. 753, 806 (1999) ("Laws that give a child's caregivers the status of long-term custodians but deny them the status of parents carry an explicit social meaning, that the caregivers are something less than the true parents to the child ...."); Sarah E. Waldeck, Using Male Circumcision to Understand Social Norms as Multipliers, 72 U. CIN. L. REV. 455, 492-99 (2003) (describing how social norms factor into parents' decisions whether to circumcise their infant sons).

${ }^{31}$ See, e.g., Robert Cooter, Expressive Law and Economics, 27 J. LEGAL STUD. 585, 585 (1998) (noting that "[d]uring the period of segregation, social norms punished people for refusing to discriminate ... [but a]fter the law imposed desegregation, new social norms developed to punish discrimination"); Gertrud M. Fremling \& Richard Posner, Status Signaling and the Law, with Particular Application to Sexual Harassment, 147 U. PA. L. REV. 1069, 1069 (1999) (positing a connection between status and offensiveness in the law of sexual harassment); Richard H. McAdams, Cooperation and Conflict: The Economics of Group Status Production and Race Discrimination, 108 HARV. L. REV. 1003, 1008, 1026-27 (1995) (discussing "intra-group cooperation and inter-group conflict" and how these phenomena interplay with social norms).

${ }_{32}$ See Cass R. Sunstein, Social Norms and Social Roles, 96 Colum. L. Rev. 903, 914, 918, 937 (1996) (listing various types of social norms). 
thereby encouraging nonresidential fathers to remain actively involved in their children's upbringing. ${ }^{33}$

This Article proceeds in three parts. Part I illustrates the law's ability to influence social norms in the family context. This Part surveys how the law's treatment of no-fault divorce and child support has changed social norms of marriage, divorce, and parental responsibility.

Part II begins by exploring current societal expectations of postdivorce fatherhood and the law's role in maintaining these expectations. It then analyzes the empirical evidence of paternal disengagement after divorce, and both the literature suggesting that fathers' presence is important to children's development and the literature arguing that economic support is what matters. It is well established that raising children is a challenging undertaking and that two people sharing the responsibilities of parenthood are generally better than one. To the extent that the second person will be the father in the majority of cases, ${ }^{34}$ I argue that the father is important not only for his

\footnotetext{
${ }^{33}$ Although unmarried fathers are even less likely than divorced fathers to maintain contact with or support children with whom they do not reside, this Article focuses on divorced fathers only. My focus is on how the law can encourage fathers to maintain and nurture a parental relationship with their children, rather than on how the law can facilitate a relationship where one has never existed. The vast majority of divorced fathers share or have shared a parental relationship with their children by virtue of having lived with them. In contrast, many unmarried fathers have never established paternity or shared a parental relationship with their children. POPENOE, supra note 3 , at 20 . Thus, encouraging them to parent their children may require a different approach than the mechanisms I propose, which are aimed at encouraging divorced fathers to parent. Cf. Frank L. Mott, When Is a Father Really Gone? Paternal-Child Contact in Father-Absent Homes, 27 DEMOGRAPHY 499, 500 (1990) ("From a psychological perspective, it is not unlikely that the implications of never having had a father present in the home are quite distinct from having had a father present, albeit for only a short time."). Consequently, any discussion of unmarried fathers is beyond the scope of this Article.

${ }^{34}$ I am not arguing that two women or a mother and her new husband cannot successfully raise a child. Same-sex couples and stepparent families can, and do, successfully raise children. The majority of divorced mothers, however, do not remarry, and if they do, that marriage is more likely to fail. See Peggy O'Crowley, For Better or Worse, Jerseyans Accept the End of Marriage, STAR-LEDGER (Newark), Oct. 5, 2003 (stating that, while "four out of 10 first marriages will end in divorce," two out of three subsequent marriages end in divorce), available at http://www.nj.com/specialprojects/ index.ssf?/specialprojects/divorce/end.html (last visited Jan. 30, 2005). Divorced mothers are also unlikely to have a female partner as a coparent. Although it is impossible to know how many divorced custodial mothers cohabitate with women partners or are in lesbian relationships, it is safe to say that they are a small minority of divorced mothers. See generally Dan Gilgoff, The Rise of the Gay Family, U.S. NEws \& WORLD REP., May 24, 2004, at 40, 40-41 (estimating that "upwards of a million" children are being raised by single gay parents and around 160,000 families have two gay parents). As of
} 
economic contribution, but also because, in most cases, he will be the logical second person to participate with the residential parent in child rearing.

Part III examines the reasons some fathers nurture their children while others, including fathers who were very involved in their children's upbringing during the marriage, disengage from their children after divorce. This Part summarizes current custody approaches and analyzes assertions that child custody laws are biased against fathers. It also addresses divorced fathers' complaints that "visitation" itself deters them from exercising a parental role after divorce.

Part IV examines the role of social norms in encouraging or deterring nonresidential fathers from parenting their children, and it proposes that the law adopt a presumption of joint legal custody and require that nonresidential parents participate in their children's upbringing. Drawing on norms theorists' analyses of how social norms arise, this Part argues that-even with minimal or no legal enforcement-these legal reforms can trigger a norm of paternal involvement after divorce.

\section{LAW AND SOCIAL NORMS}

Norms theorists have defined social norms as "social attitudes of approval and disapproval, specifying what ought to be done and what ought not to be done." ${ }^{36}$ Because people "care what others, even

2002, there were seventy-two million children residing in the United States. JASON FieldS, U.S. DeP'T OF COMMERCE, PUB. NO. P20-547, ChILdREN's LIVING ARRANGEMENTS AND CHARACTERISTICS: MARCH 2002, at 1 (2003). Children who reside with a lesbian mother and her partner are clearly a small minority. Thus, as a practical matter, the "natural" or default coparent in most cases will be the divorced father.

${ }^{35}$ Although an increasing number of single mothers never intended to involve the biological father in their children's upbringing, see, e.g., Jhordan C. v. Mary K., 224 Cal. Rptr. 530, 531 (Ct. App. 1986) (describing a woman's refusal to include the biological father of her child in the child's upbringing); DAVID BLANKENHORN, FATHERLESS America: Confronting OUr Most Urgent Social Problem 81 (1995) (estimating that "a rapidly growing minority of middle-class mothers"- up to nine percent of all childbirths-make "the deliberate decision to bear and raise a child without a father"); Carol A. Donovan, The Uniform Parentage Act and Nonmarital Motherhood-by-Choice, 11 N.Y.U. REV. L. \& Soc. CHANGE 193, 193 (1982-1983) (stating that "[a]n increasing number of unmarried women are choosing to become mothers. . . . intending to raise their child without the father's participation"), most women who decide to bear a child do so with the expectation that the father will be raising the child along with them.

${ }^{36}$ Sunstein, supra note 32, at 914; see also Cooter, supra note 31, at 587 ("[A] norm exists when almost everyone in a community agrees that they ought to behave in a particular way in specific circumstances, and this agreement affects what people actually do."). 
strangers, think of them," ${ }^{37}$ social norms give community members the power and authority to punish those who engage in undesirable behavior by expressing disapproval or shaming them. ${ }^{38}$ Individuals follow social norms because they fear "external nonlegal sanctions," such as being shunned by their neighbors or colleagues, and/or because they have internalized the obligation and will experience guilt if they violate the norm. ${ }^{39}$ To illustrate, an individual may engage in an unpleasant task such as recycling (even though the risk of legal sanction is minimal) because (1) she fears her neighbors' disapproval (the external nonlegal sanction) if they discover that she does not recycle, and (2) she feels obligated to recycle because she has internalized the norm that good neighbors recycle (self-sanction).

There is a growing body of scholarship devoted to the relationship between the law and social norms in the family context. ${ }^{40}$ For exam-

${ }^{37}$ Richard H. McAdams, An Attitudinal Theory of Expressive Law, 79 OR. L. REv. 339, $342(2000)$.

${ }^{38}$ Eric A. Posner, Law, Economics, and Inefficient Norms, 144 U. PA. L. REV. 1697, 1699 (1996); see also Sunstein, supra note 32, at 915 ("[S] ocial norms are enforced through social sanctions that are, to say the least, pervasive."). A norm resembles a law, "except that a private person [such as a neighbor] sanctions the violator of a norm, whereas a state actor [such as a police officer or judge] sanctions the violator of a law." Posner, supra, at 1699; see also Robert D. Cooter, Three Effects of Social Norms on Law: Expression, Deterrence, and Internalization, 79 OR. L. REv. 1, 4-5 (2000) (noting that "a law is an obligation backed by a state sanction" and "a social norm is an obligation backed by a social sanction"). Of course, the same behavior could elicit both legal and nonlegal enforcement.

${ }^{39}$ McAdams, supra note 30, at 340; see also Cooter, supra note 31, at 585 ("When many people in a community internalize an obligation, it becomes a social norm."). For example, as Professor Sunstein has illustrated, law enforcement officers generally do not enforce laws requiring dog owners to clean up after their dogs, but such laws signal appropriate behavior and implant the expectation of social disapproval, and hence shame, in those who deviate from that behavior. Cass R. Sunstein, On the Expressive Function of Law, 144 U. PA. L. REV. 2021, 2032-33 (1996). Thus, people clean up after their dogs because they would be ashamed if it became apparent to their neighbors that they do not clean up after their dogs, even though violation of the law is unlikely to lead to any legal sanctions. Id. at 2032.

${ }^{40}$ See, e.g., Scott, supra note 29, at 1905 (arguing that no-fault divorce laws may have "undermined beneficial norms that contributed to marital stability"); see also SteVEn L. NOCK, MARRIAGE IN MEN's Lives 23 (1998) (discussing how domestic relations laws reflect social norms); William Bishop, 'Is He Married?': Marriage as Information, 34 U. TORONTO L.J. 245, 248-54 (1984) (discussing the signaling effects of the institution of marriage and the consequences for social norms); Meyer, supra note 30, at 806 (discussing the effects of guardianship and adoption laws on social norms of parenthood); Eric A. Posner, Family Law and Social Norms, in THE FALL AND RISE OF FREEDOM OF CONTRACT 256, 268-72 (F.H. Buckley ed., 1999) (discussing the influence of social norms on marriage laws); Waldeck, supra note 30, at 502 (arguing that the law can be used to change norms for circumcision). 
ple, Professor Waldeck has argued that the law can shift social norms of neonatal circumcision toward a norm of noncircumcision, ${ }^{41}$ and Professors Brinig and Buckley have argued that divorce rates have been heavily influenced by social norms. ${ }^{42}$ Similarly, Professor Scott has argued that legal reforms have inadvertently weakened social norms of marriage as a lifelong commitment. ${ }^{43}$ In this Part, I focus on Professor Scott's work on law and social norms in the context of marital commitment and parenting to illustrate how the law has generally influenced social norms in the family context.

Divorce rates have risen dramatically in the last thirty years. Scholars have cited many reasons for the increase in marital instability, such as women's entry into the workforce, the women's movement, ${ }^{44}$ the sexual revolution, ${ }^{45}$ and the increase in American families' geographic mobility. ${ }^{46}$ Without denying the impact of these factors on the divorce rate, Professor Scott argues that the law's recognition of no-fault divorce in the 1970 s led to an increase in the proportion of couples ending their marriages. ${ }^{47}$ She notes that, until relatively recently, Americans thought of marriage as a lifelong commitment, in part, because the law made it virtually impossible for couples to di-

${ }^{41}$ Waldeck, supra note 30 , at 502.

${ }^{42}$ Margaret F. Brinig \& F.H. Buckley, Joint Custody: Bonding and Monitoring Theories, 73 IND. L.J. 393, 415 (1998) (noting that current divorce rates may reflect a decline in social stigma).

Scott, supra note 29, at 1905.

${ }^{44}$ See id. at 1936 (citing women's entry into the workforce and the women's movement as possible contributing factors); see also Margaret F. Brinig \& Douglas W. Allen, "These Boots are Made for Walking": Why Most Divorce Filers Are Women, 2 AM. L. ECON. REV. 126, 129 (2000) (noting that "women file for divorce more often than men" and that "some evidence suggests they are more likely to instigate separation" (emphases omitted)).

${ }^{45}$ See Kris Franklin, Note, "A Family Like Any Other Family:” Alternative Methods of Defining Family in Law, 18 N.Y.U. REV. L. \& SOC. CHANGE 1027, 1043 (1990-1991) (arguing that as a result of the sexual revolution, "marriage was no longer either inevitable or necessarily permanent, since sex was more freely available both before and outside of the matrimonial bond").

${ }^{46}$ See Ira Mark Ellman, Divorce Rates, Marriage Rates, and the Problematic Persistence of Traditional Marital Roles, 34 FAM. L.Q. 1, 7-14 (2000) (noting that states with a higher rate of "in-migration" have higher divorce rates).

${ }^{47}$ Scott, supra note 29, at 1954 \& n.143; cf. JUSTIN WOLFERS, Did UNILATERAL Divorce LaWs RaISE Divorce RATES? A RECONCILIATION AND NEW RESUlts 13 (Stanford Law Sch., John M. Olin Program in Law \& Econ., Working Paper No. 264, Aug. 2003) (unpublished manuscript, on file with author) (finding that no-fault divorce laws "led to an immediate spike in the divorce rate," but that this effect dissipated over time such that no effect could be detected after a decade), available at http:/ / papers.ssrn.com/paper.taf?abstract_id=444620. 
vorce. The law's refusal to allow couples to legally end their marriages without good cause, along with its imposition of criminal and financial penalties on spouses who violated norms of appropriate marital behavior, ${ }^{48}$ reinforced social norms of marriage as a permanent union. Although the community informally enforced marital commitment norms by shaming and shunning ${ }^{49}$ individuals who violated such norms, the law's requirement of fault grounds for divorce ${ }^{50}$ further reinforced those norms by censuring violators. ${ }^{51}$ The law even influenced the creation of norms of appropriate behavior within a marriage by defining marital norms. For example, by making adultery, cruelty, or habitual drunkenness grounds for divorce, the law clarified the type of behavior that was unacceptable within a marriage and, by implication, signaled that behavior that the law did not sanction was not so egregious. ${ }^{52}$

Although few newlyweds contemplate that their marriage might end in divorce ${ }^{53}$ Professor Scott argues that by making it easier for

48 These penalties include, for example, adultery laws. Professor Scott argues that, by making adultery a crime, recognizing the tort of interference with marital relations, and penalizing the wrongdoer spouse when distributing the marital assets, the law made it costly for spouses and third parties to violate the marital norm of sexual fidelity. Scott, supra note 29, at 1931. The law's refusal to recognize nonmarital intimate relationships further reinforced marital commitment norms. Id. at 1904.

49 "Shunning" is a long-term sanction:

administered some time after the wrongdoing is detected and may be carried out by persons other than the person who discovered the violation. The enforcer can damage the violator's reputation by gossiping or badmouthing. Members of the community then may "shun" or stigmatize the miscreant or block him from attaining status positions.

Geoffrey P. Miller, Norm Enforcement in the Public Sphere: The Case of Handicapped Parking, 71 GEO. WASH. L. REV. 895, 904 (2003).

${ }^{50}$ Fault grounds for divorce included adultery, desertion, extreme cruelty, etc. See, e.g., Ala. Code \$ 20-2-1 (2004) (stating that, for example, the court has the power to grant a divorce upon the filing of one party if the other has committed adultery, has been absent for more than one year, or has become an alcoholic or drug addict following marriage).

${ }^{51}$ Scott, supra note 29, at 1924 (arguing that the law influenced social norms surrounding marriage by defining marital norms and by sanctioning norm violations when community enforcement and self-enforcement (guilt) did not deter violators).

${ }^{52} I d$. at 1931.

${ }^{53}$ Indeed, one study of engaged and recently married couples found that, while most of the couples surveyed were well aware that the divorce rate is close to fifty percent, all of them were sure that their marriage would not end in divorce. See Lynn A. Baker \& Robert E. Emery, When Every Relationship Is Above Average: Perceptions and Expectations of Divorce at the Time of Marriage, 17 LAW \& HUM. BEHAV. 439, 443 (1993) (finding that "the median response of the marriage license applicants was $0 \%$ when assessing the likelihood that they personally would divorce" (emphasis omitted)). 
spouses to end their marriage, no-fault divorce laws inadvertently "signal that marriage is a transitory commitment." ${ }^{, 54}$ Further, in contrast to the fault grounds setting forth behavioral rules during the marriage, no-fault laws-by "effectively abolish [ing] concrete rules of marital commitment"-leave spouses and community members without guidance as to appropriate standards of behavior, leaving each spouse to decide for him- or herself whether his or her behavior is appropriate. ${ }^{55}$ Professor Scott asks, "if relational failure justifies divorce, what effort must be expended before declaring that the relationship has truly failed? To what extent and in what ways are the parties obliged to act so as to avoid marital failure?"56 No-fault divorce laws do not provide any answers. Rather, their lack of concrete behavioral expectations and their provision of an easy exit destabilize marriages that could have survived in a fault-based system by weakening the commitment norms that discourage spouses from giving up on their marriages when difficulties arise. ${ }^{57}$ Legal reforms also weakened the likelihood and effectiveness of community enforcement (i.e., shaming of norm violators) because communities find it difficult to determine whether a certain behavior violates a norm when there are no longer any clear expectations of marital behavior and commitment. ${ }^{58}$ According to Professor Scott, once it became easier to obtain a divorce, more couples divorced, making divorce more common and community enforcement of marital commitment norms less effective. ${ }^{59}$ The community can sanction a small number of norm violators, but when many couples are ending their marriages community enforcement of the norm is less likely and less effective in influencing the behavior of potential violators.

Professor Scott has also shown-by analyzing the impact of child support legislation on parenting norms-how the law has influenced

\footnotetext{
${ }^{54}$ Scott, supra note 29, at 1902-03. Professor Scott argues that the legal recognition of nonmarital cohabitation relationships (i.e., palimony) has also influenced the social meaning of marriage. Id. at 1943.

${ }^{55} I d$. at 1905.

${ }^{56} I d$. at 1952.

${ }^{57}$ See id. at 1952-54 (arguing that "the broad normative commitment standard embraced by most individuals entering marriage is no longer particularized by guidelines describing specific behavioral expectations"). Following the withdrawal of legal enforcement, the number of persons divorcing increased. This increase included both those couples who would have been trapped in failed marriages before no-fault divorce laws, but also those for whom the withdrawal of legal enforcement undermined marital stability. Id.

${ }^{58} I d$. at 1952 .

${ }^{59} I d$. at 1954 .
} 
social norms regarding noncustodial parents' financial responsibility for their children. In the 1970s and early 1980s, there was a general societal consensus that parents should continue supporting their children after divorce, but failure to pay child support was not treated by the law as a serious offense. ${ }^{60}$ Although society disapproved of fathers who failed to pay child support, ${ }^{61}$ throughout this era legal enforcement of child support obligations remained lax, ${ }^{62}$ and "there was initially some uncertainty about the parameters of parental responsibility." ${ }^{, 3}$

Currently, there is a strong norm of financial responsibility for nonresidential fathers. ${ }^{64}$ Fathers who do not pay child support are now portrayed as criminals and are clearly ostracized in many communities. For example, major newspapers post photographs of "deadbeat" fathers-those who are delinquent in their child support payments-on their front pages, ${ }^{65}$ and state agencies' websites feature "wanted" ads of deadbeat parents. ${ }^{66}$ Why does society now treat non-

${ }^{60}$ See id. at 1947-48 (discussing the rise in the publicity and social stigmatization of irresponsible parents).

${ }^{61} \mathrm{Id}$.

${ }^{62}$ "Until the mid-1980s, the federal government and most states treated childsupport obligations as a private matter" between the child's mother and father. Anne C. Case et al., Explaining Trends in Child Support: Economic, Demographic, and Policy Effects, 40 DEMOGRAPHY 171, 187 (2003).

${ }^{63}$ Scott, supra note 29 , at 1948.

${ }^{64}$ See, e.g., Scott Altman, A Theory of Child Support, 17 InT'L J.L. POL'y \& FAM. 173, 190 (2003) (stating that nonpayment of child support violates a social norm).

${ }^{65}$ See Susan Edelman, Deadbeat-Dad Dragnet: Feds Nab Well-Off Men Whose Kids Live in Poverty, N.Y. PosT, Aug. 4, 2002, at 12 (listing New York's top ten deadbeat fathers), available at 2002 WL 24774401; Heidi Evans, City's Deadbeat Dads' Hall of Shame: Millions Owed by the Men Who Shirk Child Support, N.Y. DaILY NewS, Feb. 3, 2002, at 6 (listing New York's most delinquent noncustodial fathers), available at $2002 \mathrm{WL} 3165597$; see also Paul Rioux, Cops Book 14 Parents as Suspected Deadbeats, Times-PiCAYUne (New Orleans), Oct. 10, 2002, at B1 (listing the names and addresses of delinquent parents who were arrested for nonpayment), available at 2002 WL 25259499; Jason Straziuso, Miss. Seeks '10 Most Wanted' Deadbeat Dads, Commercial ApPeal (Memphis), Sept. 4, 2002, at B7 (reporting that the state of Mississippi would post photographs and information about the ten most wanted deadbeat parents in post offices, in county buildings, and online), available at 2002 WL 24946557.

${ }^{66}$ See, e.g., Most Wanted Delinquent Parents, L.A. County Child Support Servs. Dep't, at http://childsupport.co.la.ca.us/dlparents.htm (last visited Jan. 30, 2005) (listing names of parents wanted for failure to pay child support); 25 Most Wanted, Wanted by the State of New Mexico for Neglecting their Children for Not Paying Child Support, Child Support Enforcement Div., N.M. Human Servs. Dep't, at http://www.state.nm.us/hsd/ wanted.html (last visited Jan. 30, 2005) (same); Wanted for Failure to Pay Child Support, Div. of Child Support Enforcement, Ariz. Dep't of Econ. Sec., at http://www.de.state.az.us/ dcse/wanted.asp (last visited Jan. 30, 2005) (same); Wyoming's Most Wanted Irresponsible 
payment of child support as an egregious violation of a parenting norm? According to Professor Scott, child support laws strengthened vague norms of parental financial responsibility. ${ }^{67}$ Although for years there existed a general societal consensus that parents should support their children after divorce, the enactment of federal child support legislation ${ }^{68}$ in the 1980s and 1990s formally expressed this consensus. ${ }^{69}$ Further, the federal government's requirement that states enact child support guidelines, along with the creation of a comprehensive federal enforcement system, prescribed concrete rules delineating nonresidential parents' financial obligations, thereby quantifying the norm. $^{70}$

As shown in Part II.C.3, many parents do not comply with child support orders. It is undeniable, however, that compliance has increased since the enactment of federal child support enforcement legislation. $^{71}$ As Professor Scott has argued, enforcement legislation has been at least somewhat effective, not only because of its strict enforcement mechanisms, ${ }^{72}$ but also because it stimulated informal en-

Parents, Wanted Program, Child Support Enforcement, Wyo. Dep't of Family Servs., at http://dfsweb.state.wy.us/csehome/wywant02.htm (last visited Jan. 30, 2005) (same).

${ }_{68}^{6}$ Scott, supra note 29, at 1948.

${ }^{68}$ See Child Support Recovery Act of 1992, Pub. L. No. 102-521, 106 Stat. 3403 (codified in scattered sections of 18 U.S.C. and 42 U.S.C.) (imposing "a criminal penalty for flight to avoid" child support obligations); Family Support Act of 1988, Pub. L. No. 100-485, 102 Stat. 2343 (codified in scattered sections of 26 U.S.C. and 42 U.S.C.) (revising the Aid to Families with Dependent Children program to emphasize child support and establishment of paternity); Child Support Enforcement Amendments of 1984, Pub. L. No. 98-378, 98 Stat. 1305 (codified in scattered sections of 26 U.S.C. and 42 U.S.C.) (requiring mandatory income withholding and providing for incentive payments to states for improving effectiveness of child support enforcement).

${ }^{69}$ See Scott, supra note 29, at 1948 ("Child support legislation expressed a societal consensus that non-custodial parents continue to bear responsibility for their children....").

${ }^{70}$ See id. (explaining that the federal "guidelines provided concrete rules to quantify the obligation").

${ }^{71}$ See Altman, supra note 64, at 174 (noting that enforcement of child support has improved). Compare Timothy Grall, U.S. DEP'T OF CoMmerce, Pub. No. P60-212, Child Support For Custodial Mothers and Fathers: 1997, at 7 tbl.B (2000) (finding that out of 3.6 million custodial divorced mothers in the United States, roughly 1.7 million, or $47 \%$, received child support payments in 1997), with Case et al., supra note 62, at 171-72, 181-85 (noting that "30\% of children received some child-support income in 1976" and linking the enforcement of child support during the 1980s to the rise in child-support payments).

${ }^{72}$ See, e.g., 18 U.S.C. $\$ 228$ (a) (2000) (providing for federal criminal prosecution of parents who owe $\$ 5,000$ or more in child support obligations or have unpaid obligations for more than one year); 42 U.S.C. $\$ \$ 666(\mathrm{a})(8)$, (b) (3) (2000) (providing for automatic wage withholding for noncustodial parents); 42 U.S.C. $§ 666$ (f) (2000) 
forcement. $^{73}$ Many of the penalties imposed on delinquent parents seek to obtain compliance by interfering with the parents' ability to go about their daily lives-for example, by revoking their driver's or professional licenses. ${ }^{74}$ According to Professor Scott, however, there is another purpose behind many of these formal sanctions: "to stimulate norm internalization and to employ informal community enforcement as a supplement to formal sanctions." ${ }^{75}$ To illustrate, the Virginia Child Support Enforcement Agency "boots" delinquent parents' cars by attaching pink or blue immobilizing boots to the wheels. ${ }^{76}$ The primary purpose is to deprive delinquent parents of the use of their vehicles in order to motivate them to pay child support. However, the conspicuously marked boots also serve to shame the delinquent parent by making it apparent to friends, colleagues, neighbors, and family members that the owner is a "deadbeat." The policy promotes compliance because the delinquent parent not only fears the loss of the car's utility, but also wishes to "avoid community disapproval." ${ }^{77}$ Similarly, the suspension of a father's driver's or professional license alone may not motivate him to comply with a child support order, but the added risk that others in the community will learn of the sanction and know that he does not support his children makes violating the norm of parental financial responsibility significantly more costly.

As Professor Scott has shown, legal reforms designed to reinforce desirable social norms of parental financial obligation have been at least somewhat effective and relatively uncontroversial. Clearly, the law sometimes influences "norms of family obligation." plore how the law has contributed to the creation and maintenance of a norm of economic fatherhood.

\footnotetext{
(providing for nationwide personal jurisdiction by requiring states to adopt the Uniform Interstate Family Support Act).

${ }^{73}$ Scott, supra note 29, at 1926.

${ }^{74} I d$. at 1948 .

75 Id. at 1948 \& n.129 (stating that the "withdraw[al of] driving privileges and professional licenses" is likely "to generate community gossip").

${ }^{76} \mathrm{Id}$. at 1926.

77 Id.

${ }^{78} I d$. at 1904 .
} 


\section{CURrent Norms of Post-Divorce FATHERHOOD}

\section{A. Ambiguous Expectations}

For most of the twentieth century, social scientists have treated fathers as less important to children's mental and emotional development than mothers. ${ }^{79}$ This perception has led to differing expectations of mothers and fathers after divorce. For example, when a couple with children gets divorced, we still expect that the mother will have residential custody and the father will have visitation. ${ }^{80}$ Indeed, society still presumes that a mother who does not reside with her children after divorce must be unfit-a drug addict or psychologically unstable-and that she has "lost" or "relinquished" custody. ${ }^{81}$ At the same time, we assume that a nonresidential divorced father does not want and should not have residential custody. ${ }^{82}$

${ }^{79}$ See Ross D. PARKe, FATHERS 4 (1981) (noting that psychologists have studied the importance of mothers but have intentionally neglected fathers "because of our assumption that they [are] less important than mothers in influencing the developing child"); Jerry W. McCant, The Cultural Contradiction of Fathers as Nonparents, 21 FAM. L.Q. 127, 129 (1987) (stating that many people believe "children cannot experience healthy development without maternal influence but they may get along quite well without a father"); Richard Louv, The Crisis of the Absent Father, PARENTS, July 1993, at 54-55 (noting that "until very recently, the father's role as a nurturer was viewed ... as secondary to the mother's").

${ }^{80}$ Most social scientists, along with nonresidential fathers, dislike the term "visitation" because it is demeaning to parents, implying that they "visit" as opposed to parent or spend time with their children. Courts and legislatures have recently become more sensitive to how they label nonresidential parents' time with their children and many states now use terms such as "parenting time" instead of visitation. See, e.g., Jack P. Haynes, Focus on the Children, MICH. B.J., June 2002, at 27, 27 ("Since 1996, Michigan statutes have exclusively used the term 'parenting time' because the term 'visitation' often has been considered demeaning or minimizing to a non-custodial parent."); see also MicH. COMP. LAWS ANN. § 722.27a (West 2002) (using the term "parenting time"); Minn. STAT. ANN. $\$ 518.1705$ (2002) (same); BlANKENHORn, supra note 35, at 155 (discussing criticisms of the term "visiting father"); NANCY E. DOWD, REDEFINING FATHERHOOD 136-37 (2000) (asserting that "shared parenting" is a euphemism for "visitation"); WARREN FARRELl, FATHER AND CHILD REUNION: HOW TO BRING THE DADS WE NEED TO THE CHILDREN WE LOVE 187 (2001) (asserting that "visitation" suggests winners and losers and "reflects the era of the absentee father," while "parent time" evokes the image of having two parents and promotes fathers' post-divorce involvement in their children's lives).

${ }^{81}$ See Joan B. Kelly, Further Observations on Joint Custody, 16 U.C. DAVIS L. REV. 762, 767-69 (1983) (stating that women are "presumed by society, lawyers, the courts, and themselves to have a right to keep the children in their care and protection").

${ }^{82}$ See McCant, supra note 79, at 134 (arguing that there is "strong cultural bias and discrimination when [a father] seeks either custody or joint custody of his children"). 
Although society now encourages men to become more involved with childbirth and child rearing when they live with their children, ${ }^{83}$ divorced fathers still "face ambiguous messages from their families," society, and the law about their responsibilities to children with whom they do not live. ${ }^{84}$ Commentators have noted that, although the law has made clear that fathers must financially support their children after divorce, society and the law lack clear rules as to other (nonfinancial) paternal responsibilities. ${ }^{85}$ Consequently, nonresidential fathers are confused as to their proper roles after divorce. ${ }^{86}$ In most cases, a divorced mother will continue taking care of the children as she did during the marriage and, even in those rare cases where her children do not live with her after divorce, society still recognizes her as a mother. ${ }^{87}$ In contrast, society treats a divorced father as less of a father. ${ }^{88}$

${ }^{83}$ See text accompanying notes 2-11 (detailing the developing role of fathers in society).

${ }^{84}$ Judith A. Seltzer, Relationships Between Fathers and Children Who Live Apart: The Father's Role After Separation, 53 J. MARRIAGE \& FAM. 79, 81 (1991); see also TERRY ARENDELl, FATHERS \& Divorce 172 (1995) (quoting a father as stating that "[m] ost divorced fathers do not get support and understanding from their own relatives" and that because most people have been raised by their mothers while their fathers worked, his adult family members do not understand why he is "so miserable with [visitation]"); Scott Coltrane \& Neal Hickman, The Rhetoric of Rights and Needs: Moral Discourse in the Reform of Child Custody and Child Support Laws, 39 SOC. PrOBS. 400, 407 (1992) (noting that fathers complain that judges "routinely remove fathers from their children's lives and relegate men to 'little more than financial providers and occasional visitors'” (quoting Jack Arbuthnot, Fathers' Rights, 1 DAD 7, 41 (1990))).

${ }^{85}$ See Seltzer, supra note 84 , at 81 (explaining that the father's role after separation is undefined, such that " $[\mathrm{r}]$ ecently divorced fathers gingerly attempt to establish ways to stay involved in their children's lives but are uncertain about how their children and ex-wives will react to these attempts"); see also ARENDELL, supra note 84, at 172 (explaining that, while continuing financial obligations are clear, other parental responsibilities are not); DowD, supra note 80, at 139 (asserting that while fathers' "support obligations have been strengthened and regularized, no corresponding duty of care has developed"); McKenry et al., supra note 21, at 308 (noting that it is unclear what the role of the noncustodial father should be and that the divorce literature offers little guidance as to an appropriate role).

${ }^{86}$ ARENDELL, supra note 84 , at 172-73.

${ }^{87}$ See id. at 171 (noting that women are mothers regardless of marital status because there is legal and cultural support for motherhood); POPENOE, supra note 3, at 25 ("Whatever their marital state, when women bear children they generally assume responsibility for those children and continue to care for them over the course of their lives. For men, this is not the case.").

${ }^{88}$ See ARENDELL, supra note 84, at 171 (noting that unlike mothers, fathers' parental identity is disrupted by divorce as there is no conception of fatherhood that parallels the cultural idealization of motherhood). Fathers feel that society treats them as if they are "not part of the family, [not] part of society anymore [after divorce]." Id. at 
As a result of our differing perceptions and expectations of mothers and fathers, and their commitment and importance to their children, the societal norm of post-divorce fatherhood is still primarily economic. $^{89}$ In many communities, so long as a divorced father pays child support-even if he does nothing else for his children-he is perceived as a decent, maybe even a good, father. ${ }^{90}$ Even if he has little contact with his children, so long as he supports them financially he will not elicit the moral opprobrium of most of his neighbors, coworkers, or relatives. We have only to look at the labels used to describe fathers who do not financially support their children ("deadbeats," "deadbeat dads") and the law's and media's obsession with such fathers ${ }^{91}$ and contrast it with the lack of attention given to fathers I refer to as "emotional deadbeats" to conclude that society condemns economic deadbeat dads but apparently cares little about emotional deadbeats.

As Professor Dowd has argued, because being a father is equated with being an economic provider and little else, paternal disengagement does not violate societal expectations of fathering. ${ }^{92}$ Thus, society nonchalantly accepts that many fathers will abandon their children after divorce. "[T] he pattern of post-divorce fathering as limited or nonexistent nurturing is accepted as "natural." "93 Further, many people assume that fatherhood is of little significance to most men and that they can easily walk away from their children after divorce without suffering any negative psychological or emotional consequences. ${ }^{94}$

64; see also BLANKENHORN, supra note 35, at 65 (1995) ("Compared to mothers, fathers are less born than made. As a social role, fatherhood is less the inelastic result of sexual embodiment than the fragile creation of cultural norms.").

${ }^{89}$ See Nancy E. Dowd, Rethinking Fatherhood, 48 FLA. L. REV. 523, 529 (1996) (noting that " $[\mathrm{t}]$ he dominant expectation and focus of the divorce model is economic fathering, i.e., the payment of child support"); Seltzer, supra note 84, at 80-81 (pointing to the "[w]ide variation in postdivorce" levels of paternal involvement as evidence that there are no "clear rules or norms" of post-divorce fatherhood).

${ }^{90}$ DowD, supra note 80, at 139.

${ }^{91}$ See supra notes 65-66 and accompanying text (citing newspapers and government websites that stigmatize delinquent parents as "deadbeats").

${ }^{92}$ See Dowd, supra note 89, at 530 (discussing the "economic model" of fatherhood and describing "post-divorce fathering as limited or nonexistent").

${ }^{93} I d$. She notes that society would be seriously alarmed if mothers were abandoning their children at similar rates as fathers because we have different expectations of what it means to be a mother. See id. at 523 (noting that fathers abandon their children far more often than do mothers).

${ }^{94} I d$. 
As shown below, ${ }^{95}$ these assumptions are largely inaccurate, yet they enable society to see fathers' roles after divorce as largely economic.

The law shares this view of economic fatherhood. ${ }^{96}$ In most states, so long as nonresidential fathers pay child support, they have satisfied their legal obligations to their children. ${ }^{97}$ The law does not require that nonresidential fathers see their children, provide them with moral or educational guidance, or meet their friends and teachers. It merely requires that they support their children financially; it does not require that they parent them. ${ }^{98}$ By failing to demand that nonresidential divorced fathers take a more active role in their children's lives, and by imposing few consequences when they abandon their children, the state enables disengaged parenthood and sends fathers the message that their presence is not important. ${ }^{99}$

The law also does little to encourage nonresidential divorced fathers to participate in their children's upbringing. Judges in the vast majority of states routinely order or approve custody and visitation arrangements that leave mothers with a significantly larger share of parental responsibilities after divorce or separation and that limit fathers' responsibilities to paying child support. ${ }^{100}$ By focusing on

${ }^{95}$ See discussion infra Part III.C.2.

${ }^{96}$ Although child support laws are gender neutral, because most nonresidential parents are men, it is usually fathers who are ordered to pay child support. Thus, the economic terms of nonresidential parenthood are primarily imposed on fathers. See Dowd, supra note 89, at 530 (discussing the application of technically gender neutral custody laws).

97 See id. at 529 ("[F]athers are not legally sanctioned for failure to spend time with their children that they committed to spend under custody and visitation schemes.").

${ }^{98}$ See McCant, supra note 79, at 139 (“[A father's] legal duty is to provide financially for his child. There are no obligations to create more meaningful social relations with his offspring." (quoting ARTHUR D. COLMAN \& LIBBy COLMAN, EARTH FATHER/SKY FATHER: THE CHANGING CONCEPT OF FATHERING 122 (1981))).

${ }^{99}$ See, e.g., ARENDELL, supra note 84, at 172 (discussing undefined paternal responsibilities post-divorce, aside from financial obligations). The state does not require very much from nonresidential mothers, either. It does not require that they maintain contact with their children or participate in their upbringing. Society, however, does expect mothers-even if they do not have custody-to continue nurturing their children and shuns those relatively few mothers who do not. Id. at 171 . Thus, social norms encourage nonresidential mothers to nurture their children even if the law does not. Cf. id. at 144 ("[P] aternal absence was not met with wholesale condemnation from others.").

${ }^{100}$ Cf. Dowd, supra note 89, at 529 (finding that "most custody and visitation schemes envision only a limited fathering role," one that is mostly economic); Furstenberg, supra note 1, at 209 (arguing that social norms contribute to maintenance of the status quo by denying fathers the resources to assume greater parental responsibility). 
fathers' financial contributions, to the exclusion of their nonpecuniary contributions, the law perpetuates an economic model of fatherhood. ${ }^{101}$ Indeed, one commentator has argued that "[b]y sending a distinct message to divorced fathers that they are not essential to the raising of children beyond supplying a percentage of their paychecks to the mother ... and perhaps a couple of hours a week of 'visitation'... the state has encouraged divorced fathers to abandon true fatherhood." ${ }^{\prime 12}$ As another commentator has noted, sociolegal "[s] upport for the nurturing aspect of fatherhood is very limited [indeed]." 103

Many fathers themselves define their parenting roles after divorce primarily in economic terms. ${ }^{104}$ They believe they have little influence in their children's lives after divorce. ${ }^{105}$ Many divorced fathers who pay child support and see their children sporadically describe themselves as good fathers precisely because they compare themselves, not to mothers or married fathers, but to absent fathers. ${ }^{106}$ By this standard, any level of involvement with their children indicates that they are doing a pretty good job of parenting. Thus, far from seeing their own limited involvement in their children's upbringing as deviant, "[p]arental association of any kind evoke[s] a stance of self-

101 See, e.g., Greer Litton Fox \& Priscilla White Blanton, Noncustodial Fathers Following Divorce, 20 MARRIAGE \& FAM. REv. 257, 260 (arguing that through custody laws, visitation, and child support, "society at large becomes an important player in constructing the post-divorce family," because " $[\mathrm{n}]$ ormative expectation and values about appropriate family relations are expressed through custody, visitation, and child support").

2 Cynthia A. McNeely, Lagging Behind the Times: Parenthood, Custody, and Gender Bias in the Family Court, 25 FLA. ST. U. L. REV. 891, 895 (1998).

${ }^{103}$ Dowd, supra note 89 , at 526.

${ }^{104}$ See Marilyn Ihinger-Tallman et al., Developing a Middle-Range Theory of Father Involvement Postdivorce, in FATHERHOOD: CONTEMPORARY THEORY, RESEARCH, AND SOCIAL POLICY, supra note 4, at 57, 74 (suggesting that because fathers view their post-divorce role as that of economic provider, economic well-being and stable employment will tend to strengthen their involvement with their children).

105 See James W. Loewen, Visitation Fatherhood, in Fatherhood TOdaY: MeN'S Changing Role in the Family 195, 205 (Phyllis Bronstein \& Carolyn Pape Cowan eds., 1988) (finding that while only $20 \%$ of noncustodial fathers believed they had much influence over their children, custodial mothers thought even that was an overstatement); John Leo, A Family Plan for Uncle Sam, U.S. News \& WORLD ReP., Nov. 30, 1992, at 22 (citing a study by Sylvia Ann Hewlett that found that many absent fathers were surprised by research indicating that fathers are important to children); Louv, supra note 79, at 54 (noting that some fathers vaguely understand the importance of fathering and its impact on children, but cannot express why it is so important).

106 See ARENDELL, supra note 84, at 157-58 (reporting that men interviewed for the study considered even small parenting efforts to be laudable, as compared with fathers they knew who disengaged completely). 
congratulation" because in a sense, those fathers who have some (even if sporadic) involvement with their children are surpassing the norm of uninvolved fatherhood after divorce. ${ }^{107}$ Further, one study found that most divorced fathers believe paternal absence is acceptable "under certain circumstances" and thus are not willing to condemn those fathers who have disappeared from their children's lives completely. ${ }^{108}$

Although many fathers have accepted this sociolegal norm of economic fatherhood, this may be starting to change. An increasing number of fathers are playing an integral role in their children's upbringing after divorce, ${ }^{109}$ and among middle- and upper-class fathers especially, there has been an increase in the level of involvement after divorce. ${ }^{110}$ The increase in the proportion of involved, nurturing fathers and the proliferation of fathers' rights organizations ${ }^{111}$ and books on post-divorce fatherhood ${ }^{112}$ suggest that an increasing num-

${ }^{107} I d$., at 158. One father in Arendell's study said: “[A]t least I haven't checked out like lots of guys in my situation have. I've hung in there and struggled. But most guys just leave, hang it up and leave." Id.

108 See id. at 144 .

109 See McCant, supra note 79, at 141 (noting that many fathers are rejecting the sole provider role and want to be nurturers as well).

${ }^{110}$ Cf. Furstenberg, supra note 4, at 119-20 (observing that socioeconomic status and race serve as indicators of post-divorce paternal involvement)

${ }^{111}$ See Alison S. Pally, Father by Newspaper Ad: The Impact of In Re The Adoption of a Minor Child on the Definition of Fatherhood, 13 COLUM. J. GENDER \& L. 169, 190 (2004) ("By the mid-1980s there were over 200 Fathers' Rights groups in every state."). Promise Keepers-the largest fathers' organization in the United States-was formed in 1990, and by 1996, 1.1 million men attended Promise Keepers events at twenty-two stadiums nationwide. Wade F. Horn, You've Come a Long Way, Daddy, POL'Y REV., JulyAug. 1997, at 24, 28. It "has a full-time staff of more than 400, and an annual budget of nearly $\$ 100$ million." Id. Some other visible organizations are the American Coalition for Fathers and Children, Fathers for Equal Rights, the National Congress for Men and Children, the National Fatherhood Initiative, and Parents Without Partners. For more information on these organizations, see ACFC, at http://www.acfc.org (last visited Jan. 30, 2005) (American Coalition for Fathers and Children); Men's Movement Organizations, at http://www.menweb.org/throop/orgs/orgs.html\#fatherequal (last visited Jan. 30, 2005) (Fathers for Equal Rights); National Fatherhood Initiative, at http:// fatherhood.org (last visited Jan. 30, 2005); NCFC - National Congress for Fathers and Children Quick Cover Page, at http://www.ncfc.net (last visited Jan. 30, 2005); Parents Without Partners Home Page, at http://www.parentswithoutpartners.org (last visited Jan. 30, 2005).

112 See generally ARENDELL, supra note 84 (giving voice to the male perspective of divorce, based on interviews with seventy-five divorced men); BLANKENHORN, supra note 35 (arguing that fatherlessness is at the root of America's most important social problems); BRAVER, supra note 20 (asserting, based on over 1,000 interviews with divorced couples, that the negative image of divorced dads is undeserved mythology); DOWD, supra note 80 (proposing a new definition of fatherhood centered on nurtur- 
ber of Americans are starting to believe that fatherhood entails more than financial responsibility. Indeed, more men are seeking joint or sole custody ${ }^{113}$ and fathers' advocates are fighting against what they perceive as a maternal preference in the courts and for fathers' rights to remain a part of their children's lives after divorce. ${ }^{114}$ In addition, an increasing number of Americans surveyed believe that children benefit when their fathers are involved in their upbringing; ${ }^{115}$ and the media is increasingly portraying in a positive light fathers who are actively involved in their children's upbringing. ${ }^{116}$ The fact that a significant percentage of divorced fathers and their current partners are members of fathers' rights organizations, ${ }^{117}$ and that many judges and

ing); FARRELL, supra note 80 (arguing that society is becoming increasingly supportive of men's roles in the family after divorce); JEFFERY M. LEVING, FATHERS' RIGHTS: HARD-HitTING \& FAIR ADVICE FOR EVERY FATHER INVOlvEd IN A Custody DisPuTE (1997) (offering advice to fathers on how to stay involved in their children's lives after divorce); Ross D. PARKe \& ARMin A. Brott, Throwaway Dads: The MYTHS AND BARRIERS THAT KEEP MEN FROM BEING THE FATHERS THEY WANT TO BE (1999) (identifying sociological barriers that prevent men from being more involved with their families); POPENOE, supra note 3, (explaining the historic causes of modern fatherlessness and proposing methods for rebuilding fatherhood and marriage); RICHARD A. WARSHAK, THE CUSTODY REVOLUTION: THE FATHER FACTOR AND THE MOTHERHOOD MystiQUe (1992) (arguing that the myth that mothers are uniquely suited to raise children has harmed children of divorce by reducing their contact with their fathers).

${ }^{113}$ McCant, supra note 79, at 141.

${ }^{114}$ See Dowd, supra note 89, at 530 (noting that the fatherhood movement's common ground is its claim that the legal system disregards fathers' desires to nurture their children after marital disruption); Herma Hill Kay, No-Fault Divorce and Child Custody: Chilling Out the Gender Wars, 36 FAM. L.Q. 27, 36 (2002) (noting that the fathers' movement seeks legislation for joint custody and friendly-parent laws, i.e., laws favoring as custodian the parent who will encourage the other parent's relationship with the child); Thom Weidlich, Dads' Rights Advocates Come of Age, NAT'L L.J., Mar. 13, 1995, at A1, A21 (reporting that fathers' rights' advocates want mediation, parent counseling, a presumption of joint custody, and enforcement of their visitation rights).

${ }^{115}$ See Karen Czapanskiy, Volunteers and Draftees: The Struggle for Parental Equality, 38 UCLA L. REV. 1415, 1460 (1991) ("In modern America, unlike in earlier decades, most people believe that children need mothers and fathers in their lives."); Horn, supra note 111, at 29 ("A 1996 Gallup Poll found that 79 percent of Americans believe "the most significant family or social problem facing America is the physical absence of the father from the home.”); Basia Hellwig, How Working Women Have Changed America, WORKING WOMAN, Nov. 1986, at 129, 137 ("Nine in ten Americans today agree that it is important for fathers to spend as much time with their children as mothers do ...").

${ }^{116}$ See supra note 5 and accompanying text (listing films and television shows depicting nurturing fathers).

117 See ARENDELL, supra note 84, at 48 (noting that most men in the study were aware of the men's movement and seventeen out of seventy-five had been involved in it for more than a few months). Interestingly, women comprise half the members of the fathers' movement, and many hold influential positions. Glenn Sacks \& Dianna Thompson, Why Are There So Many Women in the Fathers' Movement?, MinNEAPOLIS STAR 
politicians sympathize with their concerns, ${ }^{118}$ is further evidence that societal expectations of post-divorce fatherhood may be slowly shifting away from a norm of primarily economic fatherhood. Society may finally be ready to embrace a more involved role for fathers. ${ }^{119}$ At the very least, some Americans are wondering whether divorced fathers should be providing more than just child support to their children. ${ }^{120}$

The law has also started to recognize that fathers are important. As discussed below, fathers' advocates have been successful in abolishing express maternal preferences in child custody laws and lobbying

TRIB., June 21, 2002, available at http://www.glennsacks.com/why_are_there.htm (last visited Jan. 30, 2005).

${ }_{118}$ See ARENDELL, supra note 84, at 49 (noting that "state legislators, judges, [and] family law attorneys" are members of fathers' rights organizations, although some remain unofficial due to their professional status as upholders of the law); Weidlich, supra note 114, at A1 (quoting a family lawyer, who noted that fathers' groups were originally composed of "angry men and not many professionals ... [but $n$ ] ow we have a lot of lawyers, doctors, politicians, [and] journalists" among the members, and as a result, the movement is "more mainstream"). Indeed, in 2001, President Bush appointed a former president of the National Fatherhood Initiative as assistant secretary of family support in the Department of Health and Human Services. William C. Smith, Dads Want Their Day: Fathers Charge Legal Bias Toward Moms Hamstrings Them as FullTime Parents, A.B.A. J., Feb. 2003, at 38, 43. Many fatherhood movement leaders believe their organizations have been influential in getting Americans to realize that fathers are important. See Horn, supra note 111, at 24 (praising the emergence of the fatherhood movement and the growing awareness of the problem of fatherlessness); $c f$. Judith Stacey, Dada-ism in the 1990s: Getting Past Baby Talk About Fatherlessness, in LOST FATHERS: The Politics OF FATHERLESSNESS IN AMERICA 51, 71 (Cynthia R. Daniels ed., 1998) (arguing that misguided claims by fathers' movement scholars about the harms of fatherlessness have led to dangerous legislative proposals, such as repealing no-fault divorce).

${ }^{119}$ Of course, economic fatherhood and nurturing fatherhood are not mutually exclusive. A father can support his children financially and emotionally just as "modern" fathers who reside with their children do.

${ }^{120}$ The media has been integral to the fathers' rights movement's success in disseminating its message that fathers matter. Indeed, fathers' rights advocates credit Vice President Dan Quayle's attack on television sitcom character Murphy Brown during his reelection speech in 1992 with bringing the fathers' rights movement to the forefront. See Horn, supra note 111, at 27 (suggesting that Vice President Quayle's comment was the "birth of a movement"). Arguing that many of America's social problems are a result of the absence of fathers, Quayle remarked that "[i]t doesn't help matters when prime-time TV has Murphy Brown-a character who supposedly epitomizes today's intelligent, highly paid, professional woman-mocking the importance of fathers by bearing a child alone and calling it just another "lifestyle choice." $I d$. at 28. According to fathers' rights advocates, Quayle's speech brought many influential scholars and commentators to the forefront to defend Quayle's position that fathers matter. See id. (listing articles and books echoing Vice President Quayle's argument); see also PARKE \& BROTT, supra note 112, at 3 (noting publications written since 1990 about the demise of fatherhood); Whitehead, supra note 13, at 47 (arguing that Vice President Quayle's belief is supported by social science evidence). 
for joint custody statutes. Indeed, in almost half the states, there is a presumption or preference for joint legal custody, ${ }^{121}$ and judges increasingly award nonresidential divorced fathers significant visitation.

Regrettably, although Americans are beginning to realize that fathers should nurture their children even after the marital relationship has ended, change is slow. There is still little or no stigma attached to paternal disengagement. We do not condemn fathers who abandon their children emotionally as we do fathers who abandon their children financially. Rather, we glorify those fathers who are active participants in their children's upbringing precisely because they are surpassing our expectations of post-divorce fatherhood. Correspondingly, we accept disengaged nonresidential divorced fathers as merely "normal." In the following sections, I analyze the empirical evidence of paternal disengagement after divorce and its negative effects on children and society.

\section{B. Paternal Disengagement}

Approximately eighty percent of children reside with their mothers after divorce. ${ }^{122}$ Although most nonresidential divorced fathers are awarded visitation rights, the majority have little or no contact with their children. ${ }^{123}$ Studies have found that nearly sixty percent of children whose parents had separated had seen their fathers only several times or less in the previous year, and almost thirty percent had not

${ }^{121}$ See infra note 326 and accompanying text (listing states with a preference for, or presumption of, joint legal custody).

${ }^{122}$ See ARENDELL, supra note 84, at 38 ("More than $85 \%$ of children whose parents are divorced are in the custody of their mothers."); TERRY A. LUGAILA, U.S. DEP'T OF Commerce, Pub. No. P20-514, Marital Status and Living ARRANGEMENTS: MarCH 1998 (UPDATE) 36 tbl.6 (1998) (reporting that of the 7.1 million children living with a single divorced parent in March 1998, eighty percent were living with their mothers); Nancy E. Dowd, Law, Culture, and Family: The Transformative Power of Culture and the Limits of Law, 78 CHI.-KenT L. ReV. 785, 791 n.27 (2003) ("Maternal custody . . remains at roughly $90 \% . ")$. But see MACCOBY \& MNOOKIN, supra note 13, at 74 (finding that $67.6 \%$ of children whose parents were divorced or separated were living with their mothers).

${ }^{123}$ See Leo, supra note 105, at 22 (citing a University of Pennsylvania study finding that forty-two percent of children of divorced parents had not seen their fathers in a year); see also Furstenberg, supra note 4, at 120-21 ("The great majority of fathers who live apart from their children see them infrequently and support them irregularly." (citations omitted)); Valarie King, Nonresident Father Involvement and Child Well-Being: Can Dads Make a Statement?, 15 J. FAM. Issues 78, 79 (1994) ("[T] he great majority of nonresident fathers have infrequent contact with their children ...."); Seltzer, supra note 84 , at 79 ("Often fathers and children completely lose touch with each other." (citations omitted)). 
seen them at all in the previous year. ${ }^{124}$ An alarming twenty-three percent of divorced fathers had not had any contact with their children in at least five years. ${ }^{125}$ Although counterintuitive, at least one study reveals that those fathers who were most involved in their children's upbringing during the marriage are among those who are most likely to have little or no contact with their children after divorce. ${ }^{126}$ These formerly involved fathers apparently cope with the pain of not living with their children and not being able to parent them on a daily basis by withdrawing ${ }^{127}$ or focusing their energies elsewhere. ${ }^{128}$

${ }^{124}$ Seltzer, supra note 84 , at 85 . Seltzer's study does not distinguish between children whose parents were never married and those whose parents were married and subsequently divorced or separated. See also Sara McLanahan, Growing Up Without a Father, in LOST FATHERS: THE POLITICS OF FATHERLESSNESS IN AMERICA, supra note 118 , at 85,91 (stating that about twenty-nine percent of children have no contact with their noncustodial fathers); Nord \& Zill, supra note 15 (reporting that almost thirty-two percent of nonresident fathers had not visited their children in the past year). But see ARENDELL, supra note 84, at 6, 142 (noting that, although national studies have found that approximately thirty to fifty percent of divorced fathers have had no contact with their children in at least one year, only fifteen percent of the seventy-five divorced fathers interviewed in New York admitted to not having any contact with their children in at least one year, and another twenty percent admitted to visiting only occasionally); Furstenberg \& Nord, supra note 17, at 894 (finding that in a nationally representative sample forty-nine percent of children whose parents had divorced or separated had not seen their nonresident parent in at least one year).

Fathers who do not visit their children tend not to maintain contact through letters or telephone. Indeed, children are more likely to have face-to-face contact with their fathers than to have contact through telephone calls or letters. Seltzer, supra note 84 , at 85 .

${ }^{125}$ Furstenberg et al., supra note 25, at 696 . In contrast, only $6.8 \%$ of children who did not reside with their mothers had not had any contact with them in the last five years. Furstenberg, supra note 15, at 663 tbl.6.

${ }^{126}$ Geoffrey L. Greif, When Divorced Fathers Want No Contact with Their Children: A Preliminary Analysis, 23 J. DIVORCE \& REMARRIAGE, 1995, at 75, 76 (citing a study showing that fathers who were very involved during the marriage were more likely than uninvolved fathers to reduce contact with their children after divorce). But see Ross D. PARKE, FATHERHOOD 195 (1996) ("[P] redivorce parenting is not a good barometer of how involved a father will be with his children after the divorce.”); Kruk, supra note 13, at 20 (citing three studies finding "little association between the closeness of fatherchild relationships before and after divorce").

${ }^{127}$ See Greif, supra note 126, at 76 ("The implication is that, in order to deal with their unhappiness over their changing parental status, fathers withdraw."); see also infra Part III.C (discussing reasons fathers disengage from their children).

${ }^{128}$ Fathers who do not maintain relationships with or support their children from a previous marriage are often actively involved in raising the children with whom they currently reside-their stepchildren or biological children from their current marriage or relationship. See Furstenberg, supra note 4, at 121 ("[M] en may eschew responsibilities for children from a prior marriage even as they assume them in a new family."). Social scientists refer to this phenomenon as "child swapping," whereby men relinquish support (both financial and emotional) of children from their first marriage in 
Sadly, only twenty-five percent of children whose parents are divorced see their fathers at least weekly. ${ }^{129}$ Unfortunately, those fathers who do spend time with their children are often not parenting them, but rather, are entertaining them. ${ }^{130}$ The majority of nonresidential fathers behave more like uncles, or what commentators refer to as "Disneyland Daddies," than fathers. ${ }^{131}$ Rather than helping their chil-

favor of the biological children or stepchildren from their current marriage or relationship. Furstenberg, supra note 1, at 203; see also POPENOE, supra note 3, at 33 ("Many studies have shown that stepfathering acts to diminish contact between original fathers and their biological children.”).

${ }^{129}$ Seltzer, supra note 84, at 86 (finding that after divorce, $12.4 \%$ of children saw their fathers several times per week and another $12.4 \%$ saw them weekly); see also McLanahan, supra note 124, at 91-92 (looking at both marital and nonmarital children and finding that only thirty-five percent of children whose parents live apart see their fathers weekly).

Older children see their fathers even less frequently since paternal contact gradually decreases over time. See Furstenberg, supra note 15, at 664 (noting that contact between children and their nonresident fathers starts to drop off twelve months after separation and drops off dramatically after the second year); Furstenberg \& Nord, supra note 17, at 895 tbl.1 (finding that the average child sees their nonresident parent 7.4 days a month in the first two years after separation, but only twice a month after that; and after ten years, seventy-four percent of children have no contact with their nonresident parents); Maggie Gallagher, Father Hunger, in LOST FATHERS: THE POLITICS OF FATHERLESSNESS IN AMERICA, supra note 118, at 163, 167 (noting that ten years after divorce, "two-thirds of all children of divorce have virtually no contact with their fathers"); Loewen, supra note 105, at 210 (citing studies finding that "most visitation fathers play only peripheral roles in their children's lives by about the third year after divorce").

${ }^{130}$ See Czapanskiy, supra note 115, at 1449 (noting that very few children stay overnight at their noncustodial parent's home or engage in daily activities with them, and instead the parent's "contact is sporadic and primarily social," rather than parental); McKenry et al., supra note 21, at 307 (citing a study that found that nonresidential fathers are emotionally distant from their children, and may seem to act more like a friend than a parent).

Some scholars have remarked that noncustodial fathers' interaction with their children after divorce may not be all that different from their interaction with them when they resided in the same household, as most fathers in intact families have traditionally spent little time directly participating in child care or interacting with their children. See Czapanskiy, supra note 115, at 1435 ("The average father living with his child spends less than ten minutes a day caring for his child ...."); Furstenberg, supra note 4, at 121 (noting that some scholars argue that "this pattern of shadow fathering-a family role without much substance-in fact parallels relatively weak ties among fathers and their children who reside together").

${ }^{131}$ See Andrew Schepard, Taking Children Seriously: Promoting Cooperative Custody After Divorce, 64 TEX. L. REV. 687, 710 (1985) (noting that when children see their nonresidential fathers on holidays and weekends only, they perceive the relationship as "pure fun and games" rather than as a parent-child relationship). Noncustodial fathers who parent their children by including them "in mundane everyday routines such as shopping, reading, visiting, doing homework, or simply watching television to- 
dren with their homework or doing routine chores with them, most nonresidential divorced fathers take their children to dinner, the movies, or the mall. ${ }^{132}$ In other words, they visit with their children, but they do not parent them.

One could argue that fathers' disengagement from their children is problematic only if children are worse off as a result of their fathers' absence. As shown below, empirical evidence suggests that paternal absence may have a negative impact on children's emotional, social, and mental development, but the evidence is inconclusive.

\section{Paternal Involvement and Children's Development}

Many Americans firmly believe that children benefit from maintaining significant contact with both parents after divorce. ${ }^{133}$ Many social scientists agree. Contrary to psychologists' belief throughout most of the twentieth century that children bond only with their primary caretaker (usually the mother), child development experts have now discovered that children develop close bonds with both parents and that both the maternal and paternal bonds may be important to children's development. ${ }^{134}$ Studies have found a strong correlation between nonresidential fathers' frequent visitation and children's ad-

gether have better-adjusted children than the 'Disneyland' fathers." PARKE, supra note 126 , at 200.

${ }^{132}$ See FURSTENBERG \& CHERLin, supra note 23, at 36 (noting that, even when fathers visit their children regularly, they "assume a minimal role in the[ir] day-to-day care and supervision," behaving "more like close relatives than parents"); Jay D. Teachman, Contributions to Children By Divorced Fathers, 38 Soc. ProbS. 358, 360 tbl.1, 361 (1991) (finding that "[o]ver 75 percent of divorced fathers have never participated in the schooling of their children," and eighty-five percent have never helped their children with their homework).

${ }^{133}$ See King, supra note 123, at 79 ("The assumption behind these calls for greater father involvement is that such involvement will have positive benefits for children.").

${ }^{134}$ See Kelly, supra note 81, at 767.

$[\mathrm{M}]$ ost theoretical constructs focus almost entirely on the mother-child relationship because they were developed at a time when fathers were not believed to play an important role in the psychological development of a child. It was only in the late 1960s that the child development field discovered the father.

Id. Over the past three decades, scholarship in this area has recognized the importance of paternal as well as maternal bonds. See, e.g., John F. Coverdale, Missing Persons: Children in the Tax Treatment of Marriage, 48 CASE W. RES. L. REV. 475, 478-500 (1998) (citing several social science studies that acknowledge this point); Robert D. Hess \& Kathleen A. Camara, Post-Divorce Family Relationships as Mediating Factors in the Consequences of Divorce for Children, J. Soc. Issues, 1979, at 79, 94 (finding that a child's relationship with the noncustodial father is as important as the relationship with the custodial mother). 
justment to the divorce. Children who have regular contact with their fathers tend to have higher self-esteem and fewer behavioral problems than children who have little or no contact with their fathers. ${ }^{135}$ Studies have also found that children adapt better to divorce when their parents share social and financial responsibility for their care than when one parent bears these responsibilities alone. ${ }^{136}$ Researchers have cautioned, however, that when parents do not cooperate with each other and visitation takes place in a high-conflict setting, the benefits to the child can be minimal or nonexistent. ${ }^{137}$ Not surprisingly, children are unlikely to benefit from a relationship with the nonresidential parent if the parents are unable to interact and communicate in a civilized manner, and the children are caught in the middle of their battles. ${ }^{138}$

${ }^{135}$ See McKenry et al., supra note 21, at 307 ("Research has repeatedly indicated that the child's subsequent adjustment is strongly related to regular and frequent patterns of visitation in nonconflictual settings.”); Jana B. Singer \& William L. Reynolds, $A$ Dissent on Joint Custody, 47 MD. L. REV. 497, 500 (1988) ("Research shows that children adjust better to divorce if they have frequent contact with both parents ...."); see also PARKE, supra note 126, at 201 ("[T] he most crucial factor influencing a good readjustment [after divorce] was a stable, loving relationship with both parents between whom friction had largely dissipated, leaving regular dependable visiting patterns that the parent with custody encouraged." (quoting Judith S. Wallerstein \& Joan B. Kelly, California's Children of Divorce, PSYCHOL. TODAY, Jan. 1980, at 67, 71) (emphasis added to original)); POPENOE, supra note 3, at 150 (finding that children who feel close to their fathers after divorce are more likely to adjust to the divorce); Ihinger-Tallman et al., supra note 104, at 60 (citing studies which "conclude that fathers are important to children's postdivorce adjustment because father contact is associated with fewer behavioral problems, higher self-esteem, and other positive indices of children's development."); Loewen, supra note 105, at 196 ("Empirical studies are unanimous that one of the most important indicators of success is the quality of post-divorce relationships with both parents."). But see Furstenberg et al., supra note 25, at 699 (finding no correlation between children's well-being after divorce and contact with the nonresidential father).

${ }^{136}$ Schepard, supra note 131, at 704; Seltzer, supra note 84, at 79.

137 See Seltzer, supra note 84, at 97 (noting that encouraging post-divorce parental cooperation may, by increasing contact between the parents, result in increased parental conflict and thus hardship for the child); see also WALLERSTEIN \& KELLY, supra note 21, at 224 (finding that post-divorce parental conflict was distressing to the children and "correlated significantly with their poor psychological adjustment"); McKenry et al., supra note 21, at 307 ("Research has repeatedly indicated that the child's subsequent adjustment is strongly related to regular and frequent patterns of visitation in nonconflictual settings." (emphasis added)).

${ }^{138}$ See PARKE, supra note 126, at 202 ("[W] hen a divorced father disagrees with his former wife about child rearing, when he has a negative attitude toward her, and when he is emotionally immature, it is better that he have little contact with the family."); Mo-Yee Lee, A Model of Children's Postdivorce Behavioral Adjustment in Maternal- and DualResidence Arrangements, 23 J. FAM. Issues 672, 676 (2002) ("The positive impact of joint 


\section{Educational and Societal Benefits}

Aside from children's "smoother" emotional adjustment to divorce when both parents remain a part of their lives, there may be educational and social benefits derived from paternal involvement. Researchers have found a positive correlation between paternal involvement and both higher IQ and better school performance. ${ }^{139}$ They have also found that children with absent fathers tend to have lower grades, higher truancy and high-school dropout rates, and lower college attendance rates than children who grew up with both parents. ${ }^{140}$

Researchers have also found a positive correlation between paternal absence and delinquent behavior and drug abuse. ${ }^{141}$ Even after controlling for family income, boys from father-absent homes have much higher delinquency rates than boys growing up with two par-

custody or dual residence on parent-child relationships is likely to disappear ... in a high conflict coparenting situation.").

${ }^{139}$ Gibbs, supra note 5, at 61 .

${ }^{140}$ See JefF Grogger \& Nick Ronan, The Intergenerational EfFects of FATHERLESSNESS ON EDUCATIONAL ATTAINMENT AND ENTRY-LEVEL WAGES 2 (U.S. Dep't of Labor, Nat'l Longitudinal Survey 96-30, 1995) (“[C]hildhood fatherlessness decreases educational attainment and adult wages ...."), available at http://www.bls.gov/ ore/pdf/n1950080.pdf; McLanahan, supra note 124, at 86-87 (noting that father-absent children "twice as likely to drop out of high school, 2.5 times as likely to become teen mothers, and 1.4 times as likely to be idle"); Whitehead, supra note 13 , at $66,69-70$ (stating that children in father-absent families are more likely to experience "academic difficulties" and are almost twice as likely to drop out of high school; also, only seventeen percent of children in father-absent families, as compared to thirty-three percent of children from two parent homes, are ranked as high-achievers); id. at 74 ("Sixtyseven percent of the college-age students from disrupted families attended college, as compared with 85 percent of other students who attended the same high schools.").

Interestingly, at least one study suggests that while fatherlessness leads to lower educational attainment amongst whites and Latinos, black children in single parent homes may acquire more education than black children living with both parents. GROGGER \& RONAN, supra, at iii. This finding is counterintuitive and Grogger and Ronan acknowledge that any conclusion requires further research. At the very least, it suggests that data should be broken out across races when studying the effects of father absence. Id. at iii, 24; see also McLanahan, supra note 124, at 88 ("[W]ith respect to educational achievement, father absence has the most harmful effects among Hispanics and the least harmful effects among blacks.").

The evidence does not suggest, however, that father-absence is the only, or primary, reason behind children's poorer educational outcomes. For example, even if all children grew up in two-parent families, the high school dropout rate would decrease by only thirty-three percent. $I d$. at 87 .

${ }^{141}$ See Whitehead, supra note 13, at 47 (concluding that children of single-parent families are more inclined "to abuse drugs[] and to be in trouble with the law"). 
ents. ${ }^{142}$ "The relationship [between father absence and juvenile delinquency] is so strong that controlling for family configuration erases the relationships between race and crime and between low income and crime." 143

One might expect father absence to negatively impact boys more than girls based on a theory that children identify with and emulate the parent who shares their gender. However, studies have found that father absence negatively impacts daughters as well. A recent thirteen-year study ${ }^{144}$ analyzing the correlation between father absence and teenage pregnancy in the United States and New Zealand revealed that "early father absence" (where fathers leave before their daughters' fifth birthdays) is strongly associated with an elevated risk of early sexual activity and teen pregnancy. ${ }^{145}$ After controlling for all of the measures of "familial and ecological stressors" generally associated with father absence-e.g., socioeconomic status, race, whether the teenage girl was cooperative or defiant in kindergarten (an indicator of future behavioral problems), whether her mother was herself a teenage mother, quality of neighborhood, quality and level of parental supervision, and quantity and level of stressful life events-teenage pregnancy rates in the United States sample were still five times higher among early father-absent girls than father-present girls. ${ }^{146}$ Notably, teenage girls whose fathers were present were less likely to be-

${ }^{142}$ See Whitehead, supra note 13, at 77 (“[E]ven after the groups of subjects are controlled for income, boys from single-mother homes are significantly more likely than others to commit crimes...."). Studies show that children of fatherless homes account for seventy percent of those at state juvenile reform institutions, but only forty percent of the general population. Gibbs, supra note 5, at 54-55. These studies include both nonmarital children and children whose parents are separated or divorced.

${ }^{143}$ Whitehead, supra note 13 , at 77 (quoting an unidentified study); see also POPENOE, supra note 3, at 56-57 (discussing behavioral and emotional problems associated with absent fathers).

${ }^{144}$ The study followed a sample of girls from the summer before kindergarten through the twelfth grade. Bruce J. Ellis et al., Does Father Absence Place Daughters at Special Risk for Early Sexual Activity and Teenage Pregnancy?, 74 CHILd DEv. 801, 803 (2003).

${ }^{145}$ The United States and New Zealand have the first and second highest teen pregnancy rates, respectively, among all Western industrialized nations. Id. at 801 . The researchers noted that:

A widely held assumption is that it is not father absence per se that is harmful to children but the stress associated with divorce, family conflict, loss of a second parent, loss of an adult male income, and so on. The current research suggests that, in relation to daughters' sexual development, the social address of father absence is important in its own right and not just as a proxy for its many correlates.

Id. at 818 .

${ }^{146} I d$. at $813-17$. 
come pregnant even where risk factors such as poverty, inadequate parental supervision, stressful life events, and defiant behavior in grade school existed. ${ }^{147}$

Some scholars argue that father-absent children's lower academic performance and increased behavioral and social problems stem from poverty rather than father absence per se. ${ }^{148}$ Thus, they argue that the main problem for father-absent families "is not the absence of a male but rather the lack of income produced by a male."149 Many studies, however, are "adjusted for differences . . . such as race, parents' education, number of siblings, and residential location." ${ }^{150}$ Thus, "socioeconomic status [alone] cannot explain why children from one-parent families are doing worse" than children from two-parent families. ${ }^{151}$ Although it is not possible to conclusively establish a causal link between paternal presence and children's educational and social outcomes, the persistence of these differences between father-absent and father-present children after controlling for socioeconomic factors suggests that fathers may have a substantial impact on their children's educational and social success independent of their economic contributions. ${ }^{152}$

${ }^{147} I d$. at 818 . The researchers speculated that girls in early father-absent families may come to believe that fathers are unreliable and unimportant, thereby accelerating the onset of sexual activity and reproduction. Id. at 817. Boys raised in father-absent homes are also more likely than boys in intact families to get a girl pregnant while in their teens. Id. One scholar has suggested, from an anthropological standpoint, that this is because these boys have learned from their absent fathers that men are not expected to contribute to child care. POPENOE, supra note 3, at 157.

148 See Downey, supra note 25, at 131-32 (highlighting scholarship addressing the role of lower incomes in the educational attainment of single-mother families).

${ }^{149}$ Id. at 132; see also FINEMAN, supra note 22, at 104-05 (citing "family values" researchers who admit that poverty may be the primary reason children in single parent homes face increased mental health risks compared to those in intact families); Louise B. Silverstein \& Carl F. Auerbach, Deconstructing the Essential Father, 54 AM. PsYCHOLOGIST 397, 399 (1999) (citing research showing that father-absent families are much more likely than two-parent families to be poor, and that "it is the negative effects of poverty, rather than the absence of a father, that lead[s] to negative developmental outcomes" for children).

${ }^{150}$ McLanahan, supra note 124, at 91-92; Whitehead, supra note 13, at 66 ("Even after controlling for race, income, and religion, scholars find significant differences in educational attainment between children who grow up in intact families and children who do not.").

${ }^{151}$ McLanahan, supra note 124, at 91.

${ }^{152}$ See id. at 92 (identifying parental involvement and supervision as two of the important noneconomic factors affecting divorced children's well-being, while loss of economic resources explains only half of the negative social and behavioral outcomes associated with divorce); see also PARKE, supra note 126 at 203 (noting that children of divorce "who maintained positive relationships with both parents had the lowest scores 
One could logically attribute the better performance of children in father-present families to the fact that two persons, as opposed to one, are dedicating time and resources to the children. ${ }^{153}$ After all, quality of parenting is higher when two parents are responsible for child rearing. ${ }^{154}$ In addition, inadequate parental supervision is associated with poor school performance and higher drop-out rates. Many mothers who worked part-time, or not at all, during the marriage have to work full-time after divorce, resulting in less time for the children. The father, because he is no longer residing with the children, is not able to provide the level (however minimal) of supervision he provided during the marriage. Thus, it is not surprising that children in single-mother homes receive less supervision than children in two-parent homes and suffer the effects of low levels of parental monitoring. ${ }^{155}$

However, even if all that children in single-parent families need are second pairs of hands and eyes to assist the primary parent with child rearing, in our society that second person is likely to be the father. In most families, even the most traditional father is likely to be involved (at least somewhat) in his children's lives, if only because they reside with him. Further, especially during the months immediately following the marital disruption, fathers are likely to feel a close attachment to their children and continue to be involved in their lives. ${ }^{156}$ Thus, it is unlikely that many fathers will need to be coaxed into fulfilling some parental responsibilities. In contrast, it may be difficult to find a third party who is willing to be that "second pair of hands" that the mother needs to help her raise the children. Even if a second pair of hands to assist with child rearing were found (for example, a grandparent or stepparent), third parties are unable, in most cases, to confer on children the benefits of paternal involvement. Children who are raised by their mothers along with a stepfather or

on measures of stress and aggression and were rated more highly on work effectiveness and social interaction with peers").

${ }^{153}$ POPENOE, supra note 3, at 139; Gibbs, supra note 5, at 61.

${ }^{154}$ See Schepard, supra note 131, at 705 ("Regular contact with both parents not only provides emotional comfort for the child whose parents divorce but also increases the quality of parenting the child receives as a result of it.").

${ }^{155}$ Seltzer, supra note 84 , at 79.

${ }^{156}$ MACCOBY \& MNOOKIN, supra note 13, at 171 fig.8.4 (discovering that six months after separation, and before a final custody order is issued, the vast majority (over $75 \%$ ) of fathers have arranged for some amount of visitation with their children and approximately $47 \%$ even have overnight visits); Kruk, supra note 13, at 23 ("The majority of fathers want and are prepared to assume partial physical care of their children after divorce."). 
grandparent do not do as well as children who are raised by their mothers and fathers. Indeed, their behavior and performance in school is comparable to, or worse than, that of children raised by a single parent alone. ${ }^{157}$ Thus, it appears that merely devoting more time and resources to children may not be sufficient. It matters to children who is devoting the time and the resources.

Although many social scientists believe that fathers are important to children's well-being - and, as noted, there is empirical evidence supporting that view-according to some scholars, "fathers are essentially redundant." 158 These scholars rely on studies showing that children raised by highly educated, relatively affluent single mothers do better emotionally, educationally, and socially than those raised by two married parents with fewer economic and educational resources. ${ }^{159}$ They conclude that responsible parenting and economic security, as opposed to fathers, are what is essential to children. ${ }^{160}$ They further dismiss older studies finding a positive correlation between paternal involvement and children's well-being ${ }^{161}$ in favor of more recent studies finding little or no correlation between paternal visitation and children's educational and social outcomes. ${ }^{162}$ Although social scien-

${ }^{157}$ See McLanahan, supra note 124, at 90 ("Children in stepfamilies do not do better than children whose mothers never remarry. Despite significantly higher family income and the presence of two parents, the average child in a stepparent family has about the same chance of dropping out of high school as the average child in a singleparent family."); $i d$. (noting that having a grandmother in the home does not lower the risk of dropping out of school or teen childbearing in single-mother families); Whitehead, supra note 13, at 71 (noting that children growing up with stepparents are doing worse than children in single families, because "[o] ther difficulties seem to offset" the benefits of increased income and another adult).

${ }^{158}$ Hawkins \& Eggebeen, supra note 11, at 959 (quoting Michael E. Lamb et al., A Biosocial Perspective on Paternal Behavior and Involvement, in PARENTING ACROSS THE LIFE SpAN: Biosocial Dimensions 111, 123 (Jane B. Lancaster et al. eds., 1987)).

${ }^{159}$ Stacey, supra note 118 , at 70.

${ }^{160}$ Id. at 71.

161 See, e.g., WALLERSTEIN \& Kelly, supra note 21, at 219 (finding that five years after divorce, "good father-child relationships appeared linked to high self-esteem and the absence of depression in children of both sexes and at all ages"); Hess \& Camara, supra note 134, at 94 (finding that a child's relationship with the noncustodial father was as important as the relationship with the custodial mother); Seltzer, supra note 84, at 79 (" $[\mathrm{W}]$ hen both divorced parents share ... responsibilities of child care, children appear to adapt better to their changed living arrangements than when mothers bear these responsibilities alone." (citations omitted)).

${ }^{162}$ See Furstenberg \& CHERlin, supra note 23, at 72-73 (finding that those teenagers who regularly saw their noncustodial fathers were as likely as teens who had little contact with their noncustodial fathers to "engage in delinquent acts and precocious sexual behavior"; "children's behavioral adjustment was also unrelated to the level of intimacy" shared with their fathers; and those children who had maintained close rela- 
tists have questioned the methodologies of these earlier studies, ${ }^{163}$ the majority of recent national studies may be similarly flawed because they do not distinguish between families characterized by high levels of parental conflict and those experiencing little conflict. Indeed, the few studies that have considered the conflict factor have found that paternal visitation has a positive effect on children's well-being if (and only if) the parents get along. ${ }^{164}$ Although exposure to high levels of parental conflict may pose a greater hazard to children than the loss of a parent, ${ }^{165}$ this does not mean that paternal contact is insignificant to children's well-being and should be avoided when parents are uncooperative with each other. Rather than accepting parental conflict as inevitable and discouraging paternal involvement where conflict is present, the goal should be to reduce parental conflict so that children may benefit from their fathers' involvement in their upbringing.

Even those researchers who have not found a positive correlation between paternal visitation and children's well-being have warned that "the possibility that father visitation has beneficial effects for children cannot be totally ruled out."166 This is prudent. Needless to say, the quantity of father-child contact must matter somewhat, because maintaining a close parent-child bond would be difficult absent some sig-

tionships with their fathers were no more likely, when interviewed at ages 18 to 23 , to be more or less successful than those who had not maintained close relationships with their fathers); Fox \& Blanton, supra note 101, at 268 ("Despite the assumption that continuing contact with the noncustodial father is important to a child's well-being following divorce, the empirical evidence to support this assumption is surprisingly thin."); Furstenberg et al., supra note 25, at 697 ("[C]hildren in maritally disrupted families were not doing better if they saw their fathers more regularly than if they saw them occasionally or not at all.”); Hawkins \& Eggebeen, supra note 11, at 959 ("[T]here is insufficient evidence "to demonstrate that fathers play a formatively significant role in child development ...." (quoting Lamb et al., supra note 158)).

${ }^{163}$ See Fox \& Blanton, supra note 101, at 268 (explaining that " $[\mathrm{t}]$ he positive outcomes of noncustodial father contact were noted in early studies that involved small, nonrepresentative samples of divorcing couples characterized by higher socioeconomic backgrounds" and researchers relying on survey data from larger and more representative samples have been unable to replicate results from the earlier results).

${ }^{164}$ King, supra note 123, at 80; see also FuRSTENBERG \& CHERLIN, supra note 23, at 75 ("[A] child who alternates between the homes of a distraught mother and an angry father will be more troubled than a child who lives with a mother who is coping well and who once a fortnight sees a father who has disengaged from his family.").

${ }^{165}$ See Stacey, supra note 118, at 68 ("Most of the harms that divorce appears to inflict on children derive not from subsequent 'fatherlessness' but from negative circumstances ... [such as] parental hostility ....").

${ }^{166}$ King, supra note 123 , at 92. 
nificant level of contact. ${ }^{167}$ Further, although the amount of time a father spends with a child is not as important as whether the child feels valued, ${ }^{168}$ a child is unlikely to feel valued if the parent does not maintain contact or make an effort to be involved in his child's life.

\section{Emotional and Psychological Benefits}

There are reasons for encouraging paternal involvement independent of its likely positive effect on children's educational and social development. First, children want to see their fathers, and they feel rejected when contact with their fathers is infrequent. ${ }^{169}$ Indeed, children at "every developmental level experience sadness and even severe depression" when contact with the nonresidential parent is in-

${ }^{167}$ Interestingly, for children the quantity of contact may be only loosely indicative of the quality and depth of the father-child relationship. For example, in a 1981 study, when children who had some contact with their fathers in the previous five years were asked how close they were to their fathers, fifty-five percent replied "quite close" or "extremely close," even though only twenty-six percent of fathers in the study spent at least twenty-four days per year with their children. Furstenberg et al., supra note 25, at 696, 698. Apparently, some children feel close to parents they do not usually see. Id. However, based on this study alone, the researchers were not willing to advocate abandoning efforts to encourage greater involvement amongst noncustodial fathers. Id. at 700 .

${ }^{168}$ PARKE, supra note 126, at 202 ("[Q] $]$ uality of contact between fathers and their children is more important than amount of contact."); see also JUDITH S. WALLERSTEIN \& SANDRA BlakesleE, SECOND Chances 149-50 (1989) (discussing how children feel abandoned by their nonresidential fathers); Gallagher, supra note 129, at 163-64 ("The real problem, from the child's point of view, is not just 'fatherlessness' but father abandonment ....").

${ }^{169}$ See WALlerstein \& Kelly, supra note 21, at 218-19 (noting that children have lower self-esteem when the noncustodial parent has only limited contact with them); WARSHAK, supra note 112, at 56 (same); Kelly, supra note 81, at 770 (noting that children have "a compelling need to maintain nourishing relationships with both loved parents").

Interestingly, having little or no contact with the nonresidential parent may increase the nonresidential parent's importance to the child. See Katharine T. Bartlett, Rethinking Parenthood as an Exclusive Status: The Need for Legal Alternatives When the Premise of the Nuclear Family Has Failed, 70 VA. L. REv. 879, 907-08 (1984) ("Total separation ... rather than causing the child to forget his absent parent, may actually increase the parent's importance to the child.”); see also WALLERSTEIN \& BLAKESLEE, supra note 168, at 234 (noting that "most children do not give up on their biological fathers" who abandoned them and instead "construct a credible image of the father they never knew from any scraps of information that they can collect and tend to idealize him in the process"); Richard S. Benedek \& Elissa P. Benedek, Postdivorce Visitation: A Child's Right, 16 J. AM. ACAD. Child Psychiatry 256, 261 (1977) (finding that children often fantasize about the absent parent). 
frequent. ${ }^{170}$ Studies have found that the relationship with the nonresidential parent is as important to children's emotional stability after divorce as the relationship with the residential parent ${ }^{171}$ and may help children deal with the grief of not living with both parents. ${ }^{172}$ In one study, adult participants reported yearning for their fathers when they were children, even though other men such as stepfathers, uncles, grandfathers, and older brothers had assumed a parental role. ${ }^{173}$ As Professor Furstenberg has noted, "in a culture where biological daddies are in short supply and other men often step in to fill the breach, children still speak longingly (and sometimes bitterly) about the fathering they missed out on." ${ }^{, 74}$ Interestingly, children whose relationships with their fathers terminate as a result of paternal disengagement following divorce do worse than children whose parents die when they are young. ${ }^{175}$ Children can understand and accept death, but they cannot accept rejection and abandonment by their fathers. ${ }^{176}$ They blame themselves, reasoning that their fathers rejected them be-

${ }^{170}$ Bartlett, supra note 169, at 907. Surprisingly, studies have found that children who have no contact with the nonresidential parent suffer more detriment than children whose parents "openly reject" them, "hurt... [their] feelings," or "exploit [them] ... for selfish purposes." Id. at 909 n.146.

${ }^{171}$ See Hess \& Camara, supra note 134, at 94 (finding that a child's relationship with the noncustodial father "is of equal importance to his or her well being and separate from the relationship with the custodial mother"); $c f$. Bartlett, supra note 169, at 909 n.147 (citing a study, WALLERSTEIN \& KeLly, supra note 21, at 266, which "found both a clear negative effect of the noncustodial parent's relative abandonment and a positive contribution by the noncustodial parent who maintained a reliable relationship with the child"); Michael E. Lamb, Noncustodial Fathers and Their Impact on the Children of Divorce, in The Postdivorce Family: Children, Parenting And Society 105, 111-17 (Ross A. Thompson \& Paul R. Amato eds., 1999) (discussing several studies suggesting the importance of fathers to children's adjustment after divorce).

${ }^{172}$ Bartlett, supra note 169, at 909 (noting that "loss of contact with absent parents is more likely to aggravate ... [loyalty] problems").

${ }^{173}$ See Furstenberg, supra note 4, at 128 (studying perceptions of fatherhood among inner-city African Americans).

${ }^{174}$ Id.; Kelly, supra note 81, at 770 (arguing that although joint custody may be difficult for young children, this difficulty "must be balanced against the emptiness and longing" the child will experience as she grows up not having close relationships with both parents).

${ }^{175}$ See POPENOE, supra note 3, at 152 ("[C] hildren [whose fathers have died] suffer much less than the children of divorce and nonmarital birth from a sense of rejection, with its associated loss of self-esteem and behavioral problems.").

${ }^{176}$ See Gallagher, supra note 129, at 164 ("The real problem, from the child's point of view, is not just 'fatherlessness' but father abandonment; not simply the absence of fathers in the home but the presence somewhere close by of a father who does not seem to care."). 
cause they were "bad" or simply unlovable. ${ }^{177}$ Further, although studies have found that a close relationship with their fathers during childhood contributes to a sense of well-being and healthy self-esteem among young adults, ${ }^{178}$ children who have little contact with their fathers are likely to have poor relationships with them later in adulthood. ${ }^{179}$

Second, paternal involvement might benefit not only children, but also fathers, mothers, and society in general. Parents who share child-rearing responsibilities after divorce find their relationships with their children and with each other to be more satisfying than do parents in families where one parent carries most of the child-rearing responsibilities after divorce. ${ }^{180}$ Paternal involvement is especially beneficial to mothers who get a break from the parenting role, even if only for an evening or weekend. Thus, dual parenting protects against the "overburden" single parents (usually mothers) bear and leads to better parenting. ${ }^{181}$

Frequent contact with their children may also be good for men and for society. Studies have found that fathers who remain in close contact with their children after divorce tend to enjoy both higher self-esteem and significantly lower rates of depression and other mental health problems than fathers who have little or no contact with their children. ${ }^{182}$ Studies have also found that children who are close

177 See WARSHAK, supra note 112, at 56-57 (noting that, when fathers disengage, children think they did something to push them away); Loewen, supra note 105, at 196 (describing how children assume they must be unlovable or their fathers would want to see them).

${ }^{178}$ See supra note 136 and accompanying text for an analysis of the father-child relationship's impact on child well-being. See also Loewen, supra note 105, at 196 (noting studies finding that children's well-being is lowered with father absence).

${ }^{179}$ See Alan L. Otten, The Lasting Impact of Divorce on Children, WALL ST. J., July 20, 1993, at B1 (reporting a study's findings that "among the 18- to 22-year-olds from disrupted families, two-thirds had poor relationships with their fathers").

${ }^{180}$ See Lee, supra note 138, at 675 (citing studies showing that joint custody can improve parent well-being).

${ }^{181}$ Id.; see also Schepard, supra note 131, at 705 ("Regular contact with both parents ... increases the quality of parenting the child receives ....").

${ }^{182}$ Fox \& Blanton, supra note 101, at 273; see also Adler, supra note 3, at 63-64 (arguing that paternal involvement benefits fathers); Greif, supra note 126, at 82 (noting the results of a study showing that a majority of fathers who claimed not to want any contact with their children were dissatisfied with their relationship with their children or felt unhappiness toward them); E. Mavis Hetherington et al., Effects of Divorce on Parents and Children, in NONTRADITIONAL FAMILIES: PARENTING AND CHILD DEVELOPMENT 233, 246 (Michael E. Lamb ed., 1982) (noting that fathers who were highly involved during the marriage but rarely saw their children after divorce felt "a great sense of loss and depression"); Ihinger-Tallman et al., supra note 104, at 72 (finding that "con- 
to both of their parents tend to have stronger personal values, have higher levels of cognitive development, and to be more stable emotionally than children who have no relationship with one parent. ${ }^{183}$ They also tend to be more empathetic and socially competent ${ }^{184}$ and might be less likely to disengage from their own children. ${ }^{185}$ These studies tentatively suggest that society as a whole would benefit from fathers' greater involvement in their children's lives.

In light of these findings, even social scientists who have found no correlation between paternal involvement and children's well-being have cautioned that "despite the mixed evidence [regarding the nonpecuniary benefits of paternal involvement], the idea that continuing contact with fathers makes a difference to a child's psychological wellbeing is so plausible and so seemingly grounded in theories of child development that one is reluctant to discount it." ${ }^{186}$ They further concede that the inconclusive evidence on the benefits of paternal involvement may be the result of the difficulty of finding involved fathers to study. ${ }^{187}$ Few nonresidential fathers are actively involved in child rearing. ${ }^{188}$ Further, those few who are involved tend not to share with their former spouses the type of cooperative parenting relationships that might be necessary for children to benefit from a relationship with both parents. ${ }^{189}$ Thus, even researchers who have criticized studies finding that paternal involvement benefits children "remain

tact with children has a stabilizing effect on men postdivorce"); Loewen, supra note 105, at 197-98 (lamenting the emotional costs experienced by noncustodial fathers).

${ }^{183}$ See Czapanskiy, supra note 115, at 1441 ("There is some evidence that a child's mental, cognitive and emotional development may be improved when the child has a close relationship with two parents.").

${ }^{184}$ See Louv, supra note 79, at 56 (discussing a twenty-six year study finding that paternal involvement was the single strongest parent-related factor in the development of empathy, and that fathers who spent time alone with their children more than twice a week-bathing, feeding and caring for their children-reared the most compassionate adults); see also Jo-Ellen Paradise, Note, The Disparity Between Men and Women in Custody Disputes: Is Joint Custody the Answer to Everyone's Problems?, 72 ST. JOHN's L. REV. 517, 552-53 (1998) (asserting that children who "spend more time with their fathers are more empathetic towards others").

${ }^{185}$ Furstenberg, supra note 4, at 134 (finding that men who had little contact with their fathers as children reported feeling "emotionally undernourished" by their fathers, and, as a result, ill-prepared to nurture their own children, and that some researchers have concluded that boys who grow up with absent fathers are more likely to be absent fathers themselves).

${ }^{186}$ FURSTENBERG \& CHERLIN, supra note 23, at 73.

${ }^{187}$ Id.

${ }^{188}$ Id.

189 See id. (noting that "most formerly married parents have difficulty establishing a collaborative style of childrearing"). 
convinced that when parents are able to cooperate in child rearing after a divorce and when fathers are able to maintain an active and supportive role, children will be better off in the long run.,190

\section{Child Support}

Although studies analyzing the effects of frequent paternal visitation on children's adjustment after divorce are conflicting, it is well established that children whose fathers pay child support tend to experience fewer behavioral and social problems and to perform better in school than children whose fathers do not. ${ }^{191}$ Furthermore, even when the parents' relationship with each other is highly conflictual, studies have shown that "the positive effects of child support for child well-being outweigh[] the negative effects of parental conflict." ${ }^{192}$ For instance, children whose fathers pay child support do better academically and socially, even if their parents are always fighting, than children whose fathers do not pay child support. ${ }^{193}$ Yet, despite harsh penalties and a billion-dollar budget devoted to child support enforcement, compliance rates are still relatively low. ${ }^{194}$ Indeed, some fathers who concede their financial ability to pay child support refuse to do so because, in their view, the law has done little to facilitate access to their children. ${ }^{195}$ Only twenty percent or less of fathers who have no contact with their children pay child support. ${ }^{196}$ In contrast, two-thirds of fathers who maintain frequent contact with their chil-

190 Id.; see also David L. Chambers, Fathers, the Welfare System, and the Virtues and Perils of Child Support Enforcement, 81 VA. L. REV. 2575, 2601 (1995) ("Children of divorce are reported to fare best when they have interactions with both parents, and the parents' relationship is cooperative.").

${ }^{191}$ See Altman, supra note 64, at 190 (noting that children who receive child support have fewer behavioral problems than those who do not); Downey, supra note 25, at 132 (observing that "the father's financial support [is] related to lower problem behavior among children"); King, supra note 123, at 80 ("The strongest effects of father involvement are found in studies that examine the payment of child support."). For example, "higher levels of child support... [are] associated with higher perceived scholastic competence and with higher math and reading scores." Id. at 87-88.

${ }^{192}$ King, supra note 123, at 92.

${ }^{193} I d$.

194 Bureau of the Census, U.S. DeP’T OF Commerce, Child Support: 1999 tbl.4 (Apr. 2000) (showing that the majority of nonresidential parents do not comply fully with child support orders); KNITZER \& BERNARD, supra note 26, at app. C, at 162 tbl.6 (noting that the total collection rates in 1995 for Tennessee, the District of Columbia, and Indiana were $11.2 \%, 10.5 \%$, and $9.8 \%$, respectively); see also ARENDELL, supra note 84 , at 88 (noting that "the rate of noncompliance is higher than that of compliance").

${ }^{195}$ ARENDELL, supra note 84, at 127-28.

${ }^{196}$ Seltzer, supra note 84 , at 87. 
dren pay child support. ${ }^{197}$ Interestingly, children do better when their fathers pay child support regardless of the amount paid. Thus, a number of researchers have suggested that the payment of child support is important in and of itself, independent of the amount. ${ }^{198} \mathrm{Re}-$ gardless of the reasons children experience fewer behavioral and social problems when their fathers pay child support, it is undisputed that children benefit from their fathers' economic support even when it is minimal, and they are more likely to receive support if their fathers are involved in their upbringing.

\section{REASONS FOR PATERNAL DISENGAGEMENT}

\section{A. Custody Law}

Many divorced fathers believe child custody laws are biased against them in favor of mothers. Given that approximately eighty percent of children living with only one parent reside with their mothers, ${ }^{199}$ fathers' perception of bias is not surprising. This is especially the case because, until the mid-1970s, child custody laws expressly favored mothers, entitling them to custody of children of "tender years" ${ }^{200}$ un-

${ }^{197}$ Id.; Geoffrey L. Greif, Single Fathers with Custody Following Separation and Divorce, 20 MARRIAGE \& FAM. REV. 213, 225 (1995) (noting a correlation between consistent payment of child support and visitation).

${ }^{198}$ King, supra note 123, at 91 ("This suggests the importance of factors beyond pure economics.”). Social scientists have speculated that child support may serve as a proxy for paternal characteristics that have positive effects on children such as the willingness to assume responsibility for the well-being of their children. See Altman, supra note 64, at 190 (arguing that payment of child support is a demonstration of love and consequently, " $[\mathrm{c}]$ hildren who receive support feel less rejected and have fewer behavioral problems and perform better in school;" thus, "[c] hild-support dollars provide a larger benefit ... than dollars from other sources").

${ }^{199}$ See supra note 122 and accompanying text.

${ }^{200}$ Children seven years of age or younger were defined as of "tender years." See State v. Baird, 21 N.J. Eq. 384, 393 (1869) (Dalrimple, J., dissenting) (“[T] he wife shall, if not an improper guardian, be entitled to the custody of the children within the age of seven years.") (citing Act of March 20, 1860, ch. 167, 1860 N.J. Laws 437, awarding custody of children younger than seven to their mothers, and its supplement, Act of March 15, 1861, ch. 115, 1861 N.J. Laws 458, extending the scope of the act to all separations unless a divorce decree specifies otherwise); see also Nancy D. Polikoff, Why Are Mothers Losing: A Brief Analysis of Criteria Used in Child Custody Determinations, 7 Women's RTS. L. REP. 235, 235 (1982) (noting that "tender years has rarely been defined, [but] the age of seven is frequently cited, perhaps as a derivation from the first English statute on the subject") (citing Justice Talfourd's Act, 1839, 2 \& 3 Vict., 54 (Eng.)). But see Weaver v. Weaver, 261 S.W.2d 145, 148 (Tenn. Ct. App. 1953) (applying maternal presumption to award mother custody of her ten-year-old son). 
less they were unfit. ${ }^{201}$ Some courts justified this tender years presumption on the ground that, as children's primary caretakers during the marriage, mothers were better prepared than fathers to meet children's physical and emotional needs. ${ }^{202}$ Other courts reasoned that mothers love their children more than fathers and that children, at least young children, needed their mothers more than they needed their fathers. ${ }^{203}$ As one court stated: "Courts know that mother love is a dominant trait in the heart of the mother, even in the weakest of women. It is of divine origin, and in nearly all cases far exceeds and surpasses the parental affection of the father." ${ }^{204}$ Fathers claim this gender bias continues today.

In the 1970s, fathers began successfully challenging the tender years presumption as inconsistent with women's pursuit of equal opportunities in the workplace. ${ }^{205}$ Furthermore, as women joined the

${ }^{201}$ Until the mid-nineteenth century, child custody laws were expressly biased in favor of fathers, granting them custody in the unlikely event of divorce or separation. See, e.g., Baird, 21 N.J. Eq. at 388 (stating "the general rule is, that the claim of the father to the persons of his infant children, is paramount to those of the mother" and that " $[\mathrm{t}]$ his rule is so entirely axiomatic that it would be idle to cite authorities in its support"); Magee v. Holland, 27 N.J.L. 86, 86 (Sup. Ct. 1858) (finding that "[t]he right of the father [to custody] was clearly paramount to that of the mother"). In the late nineteenth century, mothers and mental health experts challenged fathers' rights to custody, emphasizing mothers' role in children's day-to-day care and arguing that children's custody should be based on their best interests. See Martha Fineman, Dominant Discourse, Professional Language, and Legal Change in Child Custody Decisionmaking, 101 HARV. L. REV. 727, 737 (1988) (detailing the "adoption of the best interest of the child standard as the governing substantive principle in custody adjudications").

${ }^{202}$ See Sheehan v. Sheehan, 143 A.2d 874, 882 (N.J. Super. Ct. App. Div. 1958) (explaining that the tender years presumption is based on the idea that mothers "will take better and more expert care of ... [the] child than the father"); Elizabeth S. Scott, Pluralism, Parental Preference, and Child Custody, 80 CAL. L. REV. 615, 619-20 (1992) ("Under the tender years presumption, mothers were awarded custody of their children because they had cared for them, and thus were presumed more competent to meet their needs than were fathers.").

${ }^{203}$ See, e.g., Jenkins v. Jenkins, 181 N.W. 826, 827 (Wis. 1921) ("[N] othing can be an adequate substitute for mother love-for that constant ministration required during the period of nurture that only a mother can give because in her alone is duty swallowed up in desire; in her alone is service expressed in terms of love.").

204 Bruce v. Bruce, 285 P. 30, 37 (Okla. 1930); see also Freeland v. Freeland, 159 P. 698, 699 (Wash. 1916) (discussing "mother love").

${ }^{205}$ See, e.g., Ex parte Devine, 398 So. 2d 686, 695 (Ala. 1981) (“[T] he tender years presumption represents an unconstitutional gender-based classification which discriminates ... solely on the basis of sex."); Wetzler v. Wetzler, 570 P.2d 741, 743 (Alaska 1977) (per curiam) (rejecting the maternal presumption in favor of "the best interests of the child"); King v. Vancil, 341 N.E.2d 65, 68-69 (Ill. App. Ct. 1975) (placing burden of proof on mother to change custody arrangement); State ex rel. Watts v. Watts, 350 N.Y.S.2d 285, 291 (Fam. Ct. 1973) (holding that maternal presumption is 
workforce and some fathers began assuming greater responsibility for child rearing, a maternal preference no longer seemed justified. ${ }^{206}$ As one court rejecting the tender years presumption remarked: "The simple fact of being a mother does not, by itself, indicate a capacity or willingness to render a quality of care different from that which the father can provide." ${ }^{207}$ The tender years presumption has been largely abandoned, ${ }^{208}$ and currently, the vast majority of states decide custody disputes based on the gender-neutral, best interests of the child standard. ${ }^{209}$ Fathers' advocates and commentators contend, however, that

unconstitutional). Feminists initially supported abandoning the tender years presumption as it reinforced stereotypical gender roles and hindered women's ability to compete with men in the labor market. See Fineman, supra note 201, at 768 (“[M]others' desire for sole custody or claims for preferential consideration based on maternal status or on the functions they stereotypically perform are incompatible with the symbolic presentation of equality by liberal mainstream feminism."); Scott, supra note 202, at 618 ("[W]omen have been disadvantaged by traditional marital roles ....").

${ }^{206}$ According to the Supreme Court of Iowa:

The [maternal preference] is based at least partly on the assumption that the mother keeps the home, performs the household duties and will have more time to devote to the children and their welfare. Where, as here, both the mother and the father work... and the evidence shows the husband performed a large share of the household duties ordinarily performed by a mother [and] spent much free time with the children ... the evidence discloses [that the maternal preference] would not be proper.

Forsyth v. Forsyth, 172 N.W.2d 111, 114 (Iowa 1969).

${ }^{207}$ Watts, 350 N.Y.S.2d at 289.

208 See Stephen J. Bahr et al., Trends in Child Custody Awards: Has the Removal of Maternal Preference Made a Difference?, 28 FAM. L.Q. 247, 249 (1994) ("By 1990 all but five states had abolished the maternal preference from their statutes.”).

Furthermore, it is unlikely that the tender years presumption would have survived had it been addressed by the United States Supreme Court. See Caban v. Mohammed, 441 U.S. 380, 389 (1979) (stating that "maternal and paternal roles are not invariably different in importance," and "an unwed father may have a relationship with his children fully comparable to that of the mother"). But see DeCamp v. Hein, 541 So. 2d 708, 710 (Fla. Dist. Ct. App. 1989) (holding that statute requiring that fathers be given the same consideration as mothers in determining a child's primary residence did not abolish the tender years presumption and that common sense dictated that the girls in this case, who were under three years of age, should reside with their mother), overruled by Kuutti v. Kuutti, 645 So. 2 d 80 (Fla. Dist. Ct. App. 1994) (en banc); Wheeler v. Gill, 413 S.E.2d 860, 864 (S.C. Ct. App. 1992) (stating that the tender years presumption may tip the scales in the mother's favor when both parents are equally fit).

${ }^{209}$ Although the term "best interests of the child" is used by "mental health professionals, child advocates, government officials, and scholars. . . there is little consensus, in law, or science, about what 'best interests' means." JOSEPH GOLDSTEIN ET AL., THE Best InTERests of THE CHILD: The Least Detrimental Alternative, at xiii (1st paperback ed. 1998). Generally, the "best interests of the child" is simply the "standard by which a court determines what arrangements would be to a child's greatest benefit.” A HANDBOOK OF FAMiLy LAW TERms 77 (Bryan A. Garner ed., 2001). "[T] he 
the best interests standard as applied is no different from the maternal preference; sole maternal custody is still the norm in the majority of cases. ${ }^{210}$

Even after the maternal preference was abolished as a result of the parents' agreement ${ }^{211}$ or the court's decision, mothers obtained sole custody in the vast majority of cases. Fathers were ordered to pay child support and were granted biweekly overnight visitation. ${ }^{212}$ As the sole custodial parent, the mother had the exclusive right to make major decisions concerning the child's education, religion, and medical treatment. ${ }^{213}$ As the noncustodial parent, the father had no legal deci-

best interests of the child ... places the emphasis ... on the child's welfare rather than on the parent's interests." HOMER H. ClARK, JR., THE LAW OF DOMESTIC RELATIONS IN THE UNITED STATES $\$ 19.6$, at 825 (2d student ed. 1988). In many jurisdictions, the custody statute lists factors the court should consider in determining which custodial arrangement would be in the child's best interests, such as:

the parents' ability to agree, communicate and cooperate in matters relating to the child; the parents' willingness to accept custody and any history of unwillingness to allow parenting time not based on substantiated abuse; the interaction and relationship of the child with its parents and siblings; the history of domestic violence, if any; the safety of the child and the safety of either parent from physical abuse by the other parent; the preference of the child when of sufficient age and capacity to reason so as to form an intelligent decision; the needs of the child; the stability of the home environment offered; the quality and continuity of the child's education; the fitness of the parents; the geographical proximity of the parents' homes; the extent and quality of the time spent with the child prior to or subsequent to the separation; the parents' employment responsibilities; and the age and number of the children.

N.J. STAT. ANN. § 9:2-4(c) (West 2002).

${ }^{210}$ See ARENDELL, supra note 84, at 77 (asserting that men feel that "[ $\mathrm{t}$ ] he "best interests of the child' standard [is] a deceit for maternal custody"); MACCOBY \& MNOOKIN, supra note 13, at 283 (finding that although California has abandoned the tender years presumption, it persists as a "social norm," and in custody disputes between two fit parents, mothers usually prevail); Jed H. Abraham, Why Men Fight for Their Kids: How Bias in the System Puts Dads at a Disadvantage, FAM. ADVOC., Summer 1994, at 48, 49 ("Physical custody to the mother is still the default award across the country."); Stephanie B. Goldberg, Make Room for Daddy, A.B.A. J., Feb. 1997, at 48, 48 (mentioning anti-male "gender bias in the courts").

${ }^{211}$ A study of 933 divorced families found that in nearly eighty percent of the families (705 families), parents agreed as to which parent should have custody, and in 500 of these 705 families that were in agreement, the parents requested maternal physical custody. MACCOBY \& MNOOKIN, supra note 13, at 98, 103.

${ }^{212}$ See, e.g., Birnbaum v. Birnbaum (In re Marriage of Birnbaum), 260 Cal. Rptr. 210, 215 (Ct. App. 1989) ("The parent without custody pays child support and commonly has visitation twice a month."); see also MACCOBY \& MNOOKIN, supra note 13, at 72 (noting that visitation every other weekend is traditional).

${ }^{213}$ See In re Marriage of Birnbaum, 260 Cal. Rptr. at 215 (noting that noncustodial parents may have input but no authority in major decisions). 
sion-making authority concerning the child's upbringing. ${ }^{214}$ Feeling that sole custody relegated fathers to the role of visitor, at the same time they were challenging the tender years presumption in the courts, fathers' groups began lobbying for joint custody. ${ }^{215}$ Fathers' advocates argued that both parents are important to children's psychological, emotional, and mental development, and, thus, it would be in children's best interests to maintain a close relationship with both parents. ${ }^{216}$ Many child development experts supported joint custody, reasoning that children, especially young children, needed more than the traditional every-other-weekend visitation in order to maintain close relationships with their fathers. ${ }^{217}$ California passed the first joint custody statute in $1979,{ }^{218}$ and today all states recognize joint custody. ${ }^{219}$

Although joint custody is more common today than ever before, ${ }^{220}$ sole residential custody to one parent (usually the mother) is still the most common custodial arrangement after divorce. ${ }^{221}$ As discussed be-

214 Id.

215 See Fineman, supra note 201, at 739-40 ("[J] oint custody[] was a virtually inevitable result of the successful attacks on the old rules ....”); Elizabeth Scott \& Andre Derdeyn, Rethinking Joint Custody, 45 OHIO ST. L.J. 455, 462 (1984) (discussing fathers' lobbying efforts).

216 Steinman, supra note 2, at 758.

217 These scholars also argued that when both parents are good enough parents and each supports the other's relationship with the child, there is no basis in psychology or in law for making a rational choice between the two. Thus, the legal system, along with mental health professionals, could serve children's development by encouraging both parents to be active participants in their child's upbringing. Kelly, supra note 81, at 767 (calling for fair and balanced further research about joint custody); Steinman, supra note 2, at 758-60.

218 CAL. CIV. CODE $\$ 4600.5$ (a) (Deering 1979 \& Supp. 1984) (creating a presumption favoring joint custody) (repealed Jan. 1, 1994).

All states recognize joint custody either by statute or court ruling. Goldberg, supra note 210 , at 49. "[I]n states without joint custody statutes, courts have invoked their 'inherent' authority to award joint custody." SINGER \& REYNOLDS, supra note 135, at 497; see also Patel v. Patel, 599 S.E.2d 114, 121 (S.C. 2004) (holding that S.C. CoDE ANN. \$ 20-7-402(42) (Law. Co-op. Supp. 2003) "gives family court judges the authority 'to order joint or divided custody where the court finds it in the best interests of the child'”).

${ }^{220}$ See Paradise, supra note 184, at 559 (showing that "joint custody has become increasingly prevalent throughout the country").

${ }^{221}$ See ARENDELL, supra note 84 , at 38 (finding that only a small percentage of fathers are awarded sole residential custody after divorce while mothers continue to obtain sole residential custody in most cases); MACCOBY \& MNOOKIN, supra note 13, at 74 (finding that only a small percentage of fathers are awarded sole residential custody after divorce, while mothers continue to obtain sole residential custody in most cases); note 122 and accompanying text. According to one scholar: 
low, fathers argue that continuing gender bias in the courts and in society enables mothers to obtain residential custody and exclude fathers from their children's lives.

\section{B. Gender Bias: Reality or Perception?}

Fathers' advocates argue that the legal system, including judges, attorneys, and child development professionals, is biased against fathers, making it almost impossible for them to obtain sole or joint custody and relegating them to the role of economic providers and little else. ${ }^{222}$ In this Part, I explore fathers' assertions of gender bias in the legal system and conclude that, although gender bias continues to influence a number of custody decisions, in the majority of cases, fathers' perception of bias discourages paternal involvement after divorce to a greater degree than any actual bias that might exist. Unfortunately, legal actors may be influencing this perception of bias.

Many divorced fathers of different educational and socioeconomic backgrounds, even those with residential custody, believe that child custody laws are biased against men. ${ }^{223}$ Some have expressed feeling "raped" by the divorce and custody process. ${ }^{24}$ Although conceding that child custody laws are generally gender-neutral, fathers' advocates contend that judges favor mothers when applying the law because they view fathers as less competent parents than mothers. ${ }^{225}$

This perception of bias is not unfounded. Studies have found that the tender years presumption persists as a "social norm" and that

[Eighty-five percent] to $90 \%$ of children of formerly married parents reside with their mothers while only about $10 \%$ live with their fathers. While joint physical custody arrangements alter these figures somewhat, children in joint custody are still much more likely to end up with their mothers than their fathers.

Ross A. Thompson, The Role of the Father After Divorce, Future CHILD., Spring 1994, at 210, 215 (footnote omitted); see also infra Part IV.A.

${ }^{222}$ Greif, supra note 197, at 224 (noting that "[d] espite custody laws being written in a gender neutral language, the perception among many fathers is that the courts . . remain biased" in favor of mothers and that it is difficult for fathers to obtain sole or joint custody).

${ }^{223}$ Id.; see also ARENDELL, supra note 84, at 46-47 (discussing a father who obtained primary custody but still felt that the legal system did not protect his rights simply because he was a man).

${ }^{224}$ ARENDELL, supra note 84, at 47.

${ }^{225}$ See LEVING, supra note 112, at 2-3 (informing fathers that although the tender years presumption has been abolished, "overt gender bias inherent in the concept has survived"). 
mothers usually prevail in custody disputes between two fit parents. ${ }^{226}$ Some studies have found evidence of gender bias against fathers in the courts. For example, in 1989, a study on gender bias issued by the Massachusetts Supreme Court found that, "despite the absence of statutory or decisional authority for a maternal preference for children of tender years," some judges might be applying such a preference. $^{227}$ Similarly in 1991, the Georgia Commission on Gender Bias in the Judicial System found that there are "[c]ulturally based genderbiased beliefs that influence some judges and disadvantage fathers." ${ }^{228}$ The Commission found that some judges may have accepted societal beliefs that mothers are better parents than fathers and that young children need to be with their mothers. ${ }^{229}$ Based on these assumptions, the Commission found that some judges would not award fathers custody unless the mother was unfit, while other judges were concerned that an award of paternal custody would necessarily imply that the mother was unfit. ${ }^{230}$ Similarly, findings led the Massachusetts Committee to conclude that "stereotypes about fathers may sometimes affect case outcomes." ${ }^{231}$

Undeniably, some judges treat fathers who wish to remain involved in their children's upbringing after divorce less favorably than mothers. As one judge noted, "there remains a temptation for many judges to consider the right to custody as the mother's to lose and unless her fitness is legitimately challenged, the father's right of equal

${ }^{226}$ See MACCOBY \& MNOOKIN, supra note 13, at 283 (revealing that the maternal presumption still exists in practice, even though it is no longer good law). One study found that of 198 contested cases, mothers' requests for custody were granted in 117 cases, whereas fathers' requests for custody were granted in only 52 cases. Id. at 10304. " $[\mathrm{T}]$ he remaining 29 cases resulted in a compromise between the two requests in the custody allocated." Id. at 104.

${ }^{227}$ Gender Bias Study Comm., Mass. Supreme Judicial Court, Gender Bias Study of the Court System in Massachusetts, reprinted in 24 New ENG. L. REv. 745, 827 n.47 (1990) [hereinafter Massachusetts Report]. Regrettably, the study did not follow up and investigate how often judges apply a maternal preference.

${ }^{228}$ Ga. Comm'n on Bias in the Judicial Sys., Supreme Court of Ga., Gender and Justice in the Courts: A Report to the Supreme Court of Georgia by the Commission on Gender Bias in the Judicial System, 8 GA. ST. U. L. REV. 539, 657 (1992) [hereinafter Georgia Report]. But see Mary Ann Mason \& Ann Quirk, Are Mothers Losing Custody? Read My Lips: Trends in Judicial Decision-Making in Custody Disputes-1920, 1960, 1990, and 1995, 31 FAM. L.Q. 215, 228 tbl.2 (1997) (showing that in 1995 fathers won sole custody in forty-two percent of custody disputes); Polikoff, supra note 200, at 236 ("When fathers do want custody, their chances of winning are substantial.").

${ }^{229}$ Georgia Report, supra note 228, at 657-59.

${ }^{230} I d$. at 659-60.

${ }^{231}$ Massachusetts Report, supra note 227, at 748. 
consideration is often ignored." 232 Fathers' advocates frequently point to former Kings County (Brooklyn, New York) Family Court Chief Judge Richard Huttner's statement that there is no "bigger pain in the ass than the father who wants to get involved; he can be repulsive."233 Judge Huttner chastised a father for wanting to pick up his child after school, take him out to dinner, speak to him on the telephone daily, see him on his birthday, attend open school night, and have overnight weekend visitation, concluding that " $[\mathrm{t}]$ his type of involved father is pathological." ${ }^{234}$ Similarly, one judge in Vermont, when presented with a photograph showing the mother snorting what the judge suspected to be cocaine as well as additional evidence that she had abused the child, nevertheless awarded the mother custody because the unemployed father set a bad example for the child. ${ }^{235}$ Although the mother was not herself employed, the father was penalized for failing to conform to the norm of economic fatherhood-the expectation that fathers, but not necessarily mothers, will always be economic providers. $^{236}$

Based on these types of incidents, many fathers conclude that the majority of judges view nonresidential fathers as "visiting uncles," "someone who takes the kids to dinner one evening a week and every other weekend takes them out to play somewhere."237 Many fathers argue that most judges, who as a group are still predominantly male, probably "delegate parenting responsibilities to their wives," and as such, still believe that a father's primary role is to support the children while the mother raises them. ${ }^{238}$ As a result, judges treat them as strangers with no right to participate in their children's upbringing. ${ }^{239}$

The story of bias in custody is not as clear or one-sided as some fathers' advocates might argue. In fact, fathers are not the only ones

${ }^{232}$ Ayyash v. Ayyash, 700 So. 2d 752, 755 n.3 (Fla. Dist. Ct. App. 1997).

233 Robert E. Fay, The Disenfranchised Father, 36 AdVANCES PEDIATRICS 407, 417 (1989) (quoting former Chief Judge Richard Huttner, Kings County (Brooklyn, New York) Family Court, The Fathers Also Rise, NEw York MAGAZInE, Nov. 18, 1985, at 72).

${ }^{234} I d$.

${ }^{235}$ See Leslie A. Cadwell, Note, Gender Bias Against Fathers in Custody? The Important Difference Between Outcome and Process, 18 VT. L. REV. 215, 249-50 (1993) (highlighting the description of the case given by an attorney interviewed as part of an effort by the Vermont Task Force on Gender Bias in the Legal System to gather data from divorce cases).

${ }^{236}$ See id. at 250 (discussing the judge's biased decision making).

${ }^{237}$ ARENDELL, supra note 84, at 80.

${ }^{238} I d$. (quoting an unidentified attorney/survey respondent)

239 See id. (noting that many judges, particularly "judges in older generations," believe that fathers are not supposed to be involved in parenting). 
who are occasionally treated unjustly in custody proceedings. Mothers experience bias as well. In custody disputes, trial courts sometimes penalize mothers who work outside the home and hold them to a higher standard of parenting than they do fathers. ${ }^{240}$ For example, some courts give disproportionate weight to any parenting tasks that fathers assume while simply expecting those same activities of mothers. $^{241}$ Further, courts scrutinize mothers' behavior during the marriage and improperly consider their misconduct (e.g., adultery) in determining custody although the law is clear that such behavior is relevant only if it has an adverse effect on the child. ${ }^{242}$ The same

${ }^{240}$ Unfortunately, few child custody cases are appealed. Sylvia A. Law \& Patricia Hennessey, Is the Law Male?: The Case of Family Law, 69 CHI.-Kent L. REv. 345, 351. But when such suits are appealed, the appellate courts often find that trial courts improperly held mothers to a higher standard than fathers. See Burchard v. Garay, 724 P.2d 486, 488 (Cal. 1986) (reversing trial court award of custody to the father and rejecting trial court's custody rationale that he was "financially better off" and had remarried a woman who did not work outside the home); In re Marriage of Tresnak, 297 N.W.2d 109, 111 (Iowa 1980) (discussing the trial court's reasons for awarding father custody, in part, because mother was attending law school); Linda R. v. Richard E., 561 N.Y.S.2d 29, 33 (App. Div. 1990) (holding that the trial court inappropriately focused on mother's employment); Mary Becker, Maternal Feelings: Myth, Taboo, and Child Custody, 1 S. CAL. REV. L. \& WOMEN's STUD. 133, 158 (1992) (attributing the bias against mothers to "the different ways in which mothers and fathers utilize their time and the resulting economic consequences"); Polikoff, supra note 200, at 237-42 (arguing that fathers who seek custody are prevailing in large numbers because courts are considering inappropriate factors that prejudice mothers, such as availability of economic resources, parental employment, and fathers' remarriage).

${ }^{241}$ See, e.g., In re Marriage of Estelle, 592 S.W.2d 277, 277-78 (Mo. Ct. App. 1979) (affirming custody to working father over working mother and emphasizing that father often prepared the child's breakfast and dinner and picked her up from daycare himself); Patricia Ann S. v. James Daniel S., 435 S.E.2d 6, 16 (W. Va. 1993) (Workman, C.J., dissenting) (noting that the family law master and circuit court were inappropriately "bowled over" by the father's contributions in the evenings and on weekends); Cadwell, supra note 235, at 220 (citing a female attorney's opinion that "fathers' small child care contributions are 'overvalued' in comparison with mothers' care because mothers are expected to take primary responsibility for the care of their children").

${ }^{242}$ See, e.g., Linda R., 561 N.Y.S.2d at 31 (noting that the lower court improperly focused on mother's affair); Hansen v. Hansen, 562 A.2d 1051, 1054 (Vt. 1989) (same); Katharine T. Bartlett, Preference, Presumption, Predisposition, and Common Sense: From Traditional Custody Doctrines to the American Law Institute's Family Dissolution Project, 36 FAM. L.Q. 11, 22-23 (2002) ("[C]ourts tend to give fathers more credit than mothers for doing what is expected of mothers, to penalize mothers more than men for extramarital affairs, and to think that a mother's investment in her career is selfish while a father's is the act of a responsible provider." (footnotes omitted)); Nancy D. Polikoff, Gender and Child-Custody Determinations: Exploding the Myths, in FAMILIES, POLITICS, AND Public Policy: A Feminist Dialogue on Women and the State 183, 191 (Irene Diamond ed., 1983) (noting that women are more likely than men to be penalized for engaging in nonmarital sexual behavior); Cadwell, supra note 235, at 220, 221 (ex- 
Georgia Commission that found that culturally based gender-biased beliefs may disadvantage fathers similarly found that some "[c]ulturally based gender-biased beliefs ... [may also] disadvantage mothers." ${ }^{243}$ For example, the Commission found that some judges may have adopted the view that "a mother who works outside the home, whether because of ambition or economic necessity is less fit to be awarded custody than a man ... because these women are not 'good mothers."' ${ }^{44}$ Thus, to the extent that gender bias exists, it may work against mothers as well as fathers. Few fathers' advocates, however, believe that mothers are subject to bias. Indeed, a Vermont study finding many instances of gender bias against mothers noted a "widespread perception" among fathers of bias in favor of mothersand against fathers. ${ }^{245}$

Even when there is little or no evidence of gender bias, there is a widespread perception among nonresidential fathers that the prevalence of maternal residential custody can only be explained by gender bias. This is inaccurate. In reality, mothers' greater likelihood of obtaining custody is a result of their significantly greater involvement in their children's upbringing during the marriage. ${ }^{246}$ In determining custody, courts may consider the parents' caregiving responsibilities during the marriage-in other words, who was the primary caregiver. $^{247}$ Because most mothers, even those who work outside the home, devote more time to child care than fathers, ${ }^{248}$ courts are

plaining that "the Task Force found that mothers' 'misconduct' during or after marriage was used improperly").

${ }^{243}$ Georgia Report, supra note 228, at 657-60, 662; see also Katharine T. Bartlett, Child Custody in the 21st Century: How the American Law Institute Proposes to Achieve Predictability and Still Protect the Individual Child's Best Interests, 35 Willamette L. Rev. 467, 474 (1999) ("[G] ender bias against mothers, especially those that do not conform to gender role stereotypes, is as [sic] least as serious a problem as bias against fathers.").

${ }^{244}$ Georgia Report, supra note 228, at 662.

${ }^{245}$ Cadwell, supra note 235, at 215.

${ }^{246}$ See Massachusetts Report, supra note 227, at 825 (concluding that most women obtained primary physical custody of the children after divorce not because of any maternal preference, but based on the parties' agreement or the fact that the mother had been the primary caretaker).

${ }^{247}$ See, e.g., N.J. STAT. ANN. § 9:2-4 (West 2003) (stating that "the court shall consider ... the extent and quality of time spent with the child prior to or subsequent to the separation"); VT. STAT. ANN. tit. 15, § 665(b) (6) (1989) (considering "the quality of the child's relationship with the primary care provider"); Young v. Hector, 740 So. 2d 1153, 1157 (Fla. Dist. Ct. App. 1998) (noting that the court "should attempt to preserve and continue the caretaking roles that the parties had established" when awarding custody).

${ }_{248}$ See Czapanskiy, supra note 115, at 1435 ("The average father living with his child spends less than ten minutes a day caring for his child, while the average mother 
merely attempting to continue the patterns in place during the marriage by awarding mothers responsibility for the children's upbringing after divorce. ${ }^{249}$ The perception, however, is that courts favor mothers and see fathers as merely economic providers. ${ }^{250}$

Legal and social actors reinforce these perceptions every day. Attorneys frequently shape litigants' views and expectations of the legal system. This is most true in custody cases where decisions are generally made, not by judges, but by the parties themselves, with the advice and assistance of their attorneys. ${ }^{251}$ Attorneys who believe the legal system is biased against fathers are likely to convey those views to fathers who, as lay persons, are likely to believe them. ${ }^{252}$ Although as shown above, there is some bias against both fathers and mothers, attorneys may be playing a significant role in perpetuating the perception that bias against fathers in the child custody system is rampant. ${ }^{253}$ Fathers claim that attorneys discourage them from seeking custody by questioning their motives ${ }^{254}$ and warning them that unless a mother is a

spends several hours."); Adler, supra note 3, at 61 ("Women are still doing twice as much [child care] as men"). According to one source:

[F] athers are "available" (that is, present and accessible) to their children for about half as much time as are mothers; mothers spend about three times as much time in face-to-face interaction with children as do fathers. And mothers are overwhelmingly more likely to be the person responsible for the children-the only person at home with them, the one who stays home from work with them if they are ill, the person who arranges the child care, makes medical appointments ....

MACCOBY \& MNOOKIN, supra note 13, at 26.

${ }^{249}$ Fathers advocates argue that granting mothers custody because they perform most of the caregiving penalizes men for being financial providers. See ARENDELL, supra note 84, at 78 (discussing problems with the primary caretaker theory); Ronald $\mathrm{K}$. Henry, 'Primary Caretaker': Is It a Ruse?, FAM. Advoc., Summer 1994, at 53, 53-56 (same).

${ }^{250}$ See ARENDELL, supra note 84, at 78 (quoting one father as saying, "[n]o one asked me if I loved my children, they only asked to see my paycheck").

${ }^{251}$ Loewen, supra note 105 , at 199 (noting that "9 out of 10 custody arrangements are worked out privately among the parents and their attorneys").

${ }^{252}$ See id. at 200 (stating that "many lawyers still tell their male clients they have little chance for sole or joint custody" and citing studies finding that "considerably more... men would have contested the custody issue had the lawyer not advised against such a course"” (quoting Peter Ambrose et Al., Surviving Divorce: MeN BEYOND MARRIAGE 140 (1983))).

${ }^{253}$ For example, on the cover of his book, Jeffery Leving, who describes himself as "America's Leading Fathers' Rights Attorney," promises to teach his readers how to "[o]vercome the 'tender years' bias," thereby leading fathers to believe the tender years presumption still exists. LEVING, supra note 112, at front cover.

${ }^{254}$ See, e.g., ARENDELL, supra note 84, at 185-86 (noting that one father reported that his wife's attorney kept asking him why he was seeking custody, searching for an ulterior motive, apparently finding it insufficient that he wanted custody because he was their father). 
drug addict or child abuser, a father will almost never obtain custody. ${ }^{255}$ Indeed, one attorney surveyed by a Vermont task force on gender bias expressed these views, stating that in Vermont, "mothers 'always get[] custody unless you can prove beyond all doubt [their] incompetence."’256 Further, close to seventy percent of the surveyed attorneys and half the judges "believed that Vermont custody awards are 'always' or 'often' based 'on the assumption that, other things being equal, young children belong with their mothers."”257 Thus, attorneys and judges may be reinforcing the perception that the law favors mothers as custodial parents simply because they are women.

In their initial consultations, divorce attorneys frequently warn fathers who are considering seeking sole or joint custody that mothers obtain residential custody in eighty-five percent of all cases. ${ }^{258}$ Attorneys fail to explain to fathers that most parents agree to maternal custody without judicial intervention and that this eighty-five percent figure reflects such agreements. ${ }^{259}$ Although this warning may be useful, attorneys fuel fathers' perceptions that they will not be treated fairly in a custody dispute by not providing them with all of the facts. In reality, however, judges decide only five percent of custody disputes. ${ }^{260}$ Thus, parents, not judges, are agreeing to grant mothers sole legal and residential custody. In the relatively small number of cases where parents litigate custody, fathers are awarded sole or joint custody in

${ }^{255}$ See Cadwell, supra note 235, at 244 (noting the concern that some attorneys discourage fathers from seeking custody). The Vermont Task Force asked attorneys whether they would ever "discourage a father from seeking custody because the judge would "not give the request fair consideration." Id. at 244 n.204. Fourteen percent of male attorneys reported that they discourage fathers for this reason "often," and $24.5 \%$ discourage them "sometimes." Id. Only $4.8 \%$ of female attorneys reported that they discourage fathers for this reason "often," and $22.6 \%$ discourage them "sometimes." Id.

${ }^{256} I d$. at 220.

${ }^{257} I d$. at 219.

${ }^{258}$ See ARENDELL, supra note 84, at 79 ("Most men did not pursue sole or shared custody because... [of] the national pattern in which over $85 \%$ of children whose parents divorce go into their mother's custody.").

${ }^{259}$ Most parents do not wish to subject their children to a custody hearing and manage to come to an agreement concerning custody that a judge then approves in almost all cases. When parties do not litigate custody, they usually agree to award sole physical custody to the mother. See Bahr et al., supra note 208, at 256-57 (citing a 1993 study which found that couples agreed to sole maternal custody in eight-six percent of cases and sole paternal custody in only four percent of cases).

${ }^{260}$ Loewen, supra note 105, at 201. 
fifty to sixty-five percent of cases even where the mother was the child's primary caretaker. ${ }^{261}$

If fathers' likelihood of obtaining custody is comparable to, and possibly higher than, that of mothers, why do most children reside with their mothers after divorce? Apparently, although many fathers report wanting sole or joint custody, they do not seek it. For example, although thirty-two percent of fathers claim to want sole custody and another thirty-five percent claim to want joint custody, the leading study on joint custody found that only twelve percent of divorcing fathers seek sole custody and another six percent seek joint custody. ${ }^{262}$ The majority of fathers never filed a custody petition or even opposed the mother's petition for sole custody. ${ }^{263}$ Thus, most children end up in their mother's custody by default or as a result of their parents' mutual agreement. ${ }^{264}$

There are many reasons fathers do not seek or challenge custody. Some fathers attribute to their attorneys the gap between their stated desire for custody and the infrequency with which they seek it. ${ }^{265}$ Some commentators have speculated that fathers may not be seeking custody because they have been conditioned by society to believe that women alone should be residential parents and that men should not

${ }^{261}$ See id. (noting that fathers who seek custody prevail in half or more cases); Mason \& Quirk, supra note 228, at 228 tbl.2 (citing statistics showing that fathers won custody in forty-two percent of custody appeals, mothers prevailed in forty-five percent of cases, and twelve percent of the cases involved some form of shared custody, including 9.2\% with split custody and $2.8 \%$ with joint physical custody); Massachusetts Report, supra note 227, at 825 (finding that fathers obtain custody in $70 \%$ of cases). But see MACCOBY \& MNOOKIN, supra note 13, at 103-04 (finding that mothers obtained their preferred custodial arrangement twice as often as fathers); Bahr et al., supra note 208, at 257 (showing that fathers in Utah were awarded sole custody in only twenty-one percent of disputed cases, mothers received sole custody in fifty percent of cases, seventeen percent of fathers were awarded joint legal custody, and thirteen percent had split custody); Fox \& Blanton, supra note 101, at 261 (finding that when fathers in California sought joint custody and mothers sought sole custody, mothers prevailed in sixtyseven percent of the cases).

${ }^{262}$ MACCOBY \& MNOOKIN, supra note 13, at 99-100.

${ }^{263} I d$.

${ }^{264}$ See id. at 100 (concluding that with respect to custody requests, "mothers are more likely to act on their stated desires than are fathers"); Massachusetts Report, supra note 227, at 825 (discussing a gender bias study which found that the "pattern [of mothers receiving primary physical custody of children following divorce] does not reflect judicial bias, but the agreement of the parties and the fact that in most families mothers have been the primary caretakers").

${ }^{265}$ See Cadwell, supra note 235, at 244-45 (discussing the influence of attorneys' bias on clients' custody choices). 
seek custody barring exceptional circumstances. ${ }^{266}$ In other words, social norms dictate that divorced fathers not be residential parents.

Consequently, relatives and friends are often unsupportive of fathers' desire to have custody and try to discourage them from seeking it. $^{267}$ Along those same lines, fathers who have not been primary caretakers may doubt their competence and importance as parents. ${ }^{268}$ These feelings of inadequacy, combined with mothers' and society's expectations that mothers should and will be awarded custody, may lead some fathers to believe that mothers always get custody. Feeling defeated before they even assert a claim, they settle for liberal visitation—as their attorneys advise-and never assert a claim for custody. ${ }^{269}$ As the Massachusetts and Georgia studies conclude, even when judges are not influenced by gender bias, "perceptions of gender bias discourage fathers from seeking custody, creating a chilling effect." 270

\section{The Visiting Father}

How and why do so many fathers, including those who were very involved in their children's upbringing during the marriage, ${ }^{271}$ abandon them after divorce? As discussed above, one reason fathers are not seeking custody may be that they are convinced that the custody system is stacked against them. However, this does not explain why fathers fail to maintain contact with their children, or why so many fathers with visitation rights see their children significantly less often

${ }^{266}$ ARENDELL, supra note 84, at 79; Loewen, supra note 105, at 200; see also supra Part I.

${ }^{267}$ Loewen, supra note 105 , at 200.

268 Supra note 105 and accompanying text (noting that divorced fathers doubt their importance to their children).

269 See ARENDELL, supra note 84, at 79 (finding that many men did not seek sole or joint custody because they were sure they would fail once they learned that eighty-five percent of children live with their mothers after divorce); Abraham, supra note 210, at 48 (discussing the influence of attorneys on custody decisions); Greif, supra note 197, at 223 ("[Fathers] tended to go to court only when they believed they had a good chance of winning."). Further, because in some states courts will only award joint custody where both parents agree to it, fathers may not seek it unless they are sure the mothers will not object. See, e.g., OR. REv. STAT. § 107.169(3) (1999) ("The court shall not order joint custody, unless both parents agree to the terms and conditions of that order."); infra Part III.A (discussing joint custody).

${ }_{270}$ Georgia Report, supra note 228, at 660; see also Massachusetts Report, supra note 227, at 825 (describing the discouraging effects of gender bias on fathers).

${ }^{271}$ See supra note 126 and accompanying text (arguing that the fathers who were most involved in their children's upbringing during the marriage were among those fathers most likely to disengage from their children after the divorce). 
than they are entitled under their visitation agreements or court orders. ${ }^{272}$ In this Part, I explore the reasons nonresidential fathers disengage from their children after divorce and conclude that paternal visitation itself may discourage fathers from maintaining a relationship with their children. In other words, contrary to popular belief, many fathers disengage not because they do not love their children, but rather because of the legal and social limitations imposed by a visiting relationship. Thus, the law's actual or perceived treatment of nonresidential fathers may lead some fathers to terminate contact with their children.

\section{Vanilla Visitation and Disneyland Daddies}

Although many judges and attorneys consider the typical visitation arrangement of one weeknight and alternating weekends and holidays to be generous, many fathers complain that this "vanilla visitation" schedule is "barely enough to remain a familiar face to their children, let alone an effective and involved parent." ${ }^{273}$ They argue that visitation every other weekend is not frequent enough to maintain a parental relationship because, especially with young children, it takes time to reconnect after not seeing each other even for a short period of time. ${ }^{274}$ Further, reestablishing a connection becomes increasingly difficult as the time living apart since the divorce increases. ${ }^{275}$ Thus, fathers who see their children once or twice a week and on alternate weekends are likely to become Disneyland Daddies-fathers who spoil their children, entertain them all weekend, but who do not play a parental role. ${ }^{276}$

${ }^{272}$ Over one-third of men in one study who complained that maternal custody negatively influenced their relationship with their children had substantially less contact with the children than allowed under the visitation agreement. ARENDELL, supra note 84 , at 82 .

${ }^{273}$ Smith, supra note 118, at 42; see also Kruk, supra note 13, at 23 ("Fathers have a strong desire and need to maintain regular and frequent contact with their children after divorce. For the majority of noncustodial fathers, traditional access arrangements are extremely inadequate.").

${ }^{274}$ Children's perception of time differs from that of adults. See GOLDSTEIN ET AL., supra note 209, at 41-43 (explaining that "children have a built-in time sense based on the urgency of their instinctual or emotional needs" and describing three months as "forever" for a young child).

${ }^{275}$ See ARENDELL, supra note 84, at 153 (describing fathers' attempts to reconnect with their children as "awkward")

${ }^{276}$ See WARSHAK, supra note 112, at 77 ("As an occasional 'visitor' with his children, the noncustodial father finds it difficult to retain the same depth and diversity of parental involvement."); see also supra Part II.B (discussing Disneyland Daddies). 
Some fathers see their children infrequently precisely because they refuse to be "visitors." They claim that "[v]isitation puts you in the position that you're a visitor to your child." ceased contact with his children after he was denied joint custody expressed: "I'm a parent and parents do not visit their children. If I see my child only every other weekend, I become nothing more than a visiting uncle. I am a father in name only at this point." ${ }^{278}$ This father refused to be reduced to anything less than a full parent. Many fathers agree that visitation demeans them as parents by restricting them to seeing their children only at scheduled times, ${ }^{279}$ and argue that by relegating them to the role of a visitor, the law has taken away their parental authority. ${ }^{280}$ They are not entirely wrong. Although legally responsible for supporting their children, unless they share legal and physical custody, fathers may depend on the residential mother for information about their children's health, performance in school, athletic activities, friends, etc. ${ }^{281}$ For many fathers, the superficial nature of the visiting relationship leads to increased frustration as they realize, in the words of one nonresidential father, that "a father who is a visitor is not a father at all," ${ }^{282}$ and may eventually lead to termination of all contact.

277 ARENDELL, supra note 84, at 147.

${ }^{278}$ Id. at $146-47$

${ }^{279} I d$. at 167. In Arendell's study of seventy-five fathers, only five had unfettered access to their kids; the rest were limited to the terms of the visitation agreement. Id. Some custodial mothers allow fathers to call or see their children whenever they wish, but others have accused fathers of constantly calling as a way of monitoring the mothers' activities and have obtained court orders prohibiting fathers from calling or dropping by during nonscheduled times. According to one father:

All I want is good access so that I am not a visitor. I want to have the freedom to phone them, and I want the freedom for them to phone me. I want to be able to see them when I want without asking for permission all the time.

Carl Bertola \& Janice Drakich, The Fathers' Rights Movement: Contradictions in Rhetoric and Practice, 14 J. FAM. Issues 592, 600 (1993).

${ }^{280}$ As one father noted: "How much control does any noncustodial parent have in their child's life? How much input, how much input?" ARENDELL, supra note 84, at 147.

281 "[T] he noncustodial parent generally ... ha[d] no common law right of access to information about the child from sources such as public school records." Schepard, supra note 131, at $695 \mathrm{n} .15$ (1985) (citations omitted). Although statutes now require that noncustodial parents be granted access to all school, medical and dental records, $i d$., many parents still encounter difficulties. See ARENDELL, supra note 84, at 186 (discussing the problems encountered by one noncustodial father in trying to obtain information regarding his child).

${ }^{282}$ Judith Bond Jennison, The Search for Equality in a Woman's World: Fathers' Rights to Child Custody, 43 Rutgers L. REV. 1141, 1178 (1991) (internal quotations omitted). 


\section{Emotional Pain}

Researchers have discovered that many men experience a "severe sense of loss" after a divorce and find visitation emotionally painful. ${ }^{283}$ Understandably, the anguish is greater for fathers who were highly involved in their children's upbringing during the marriage since they must become accustomed to having drastically reduced, structured, and scheduled contact, as well as losing the daily routine (i.e., bathing, dressing, feeding) of their relationship with their children. ${ }^{284}$ Some fathers, especially those who were very involved and attached to their children during the marriage, deal with the pain of trying to maintain a close relationship with them after divorce by limiting or curtailing contact. ${ }^{285}$ Rather than be "emotional wrecks" during and after a visit because they dread the anguish they will endure once the visit is over, many fathers avoid contact altogether. ${ }^{286}$ Scholars have concluded that " $[\mathrm{t}]$ he pain of the visits themselves-their brevity,

283 See H. Jay Folberg \& Marva Graham, Joint Custody of Children Following Divorce, 12 U.C. DAVIS L. REV. 523, 555 (1979) (explaining that many men are so "overwhelmed" by the situation that they simply "give up").

${ }^{284}$ See Kruk, supra note 13, at 21 ("Those fathers most attached to their children before divorce are most likely to suffer the negative effects of the loss or absence of their children and their fathering role ....”). Interestingly, for some less involved fathers-more traditional fathers-bimonthly visitation results in greater involvement in their children's upbringing than during the marriage. They are actually spending more time alone with the children than ever before. Id.

${ }^{285} I d$. at 20-21 (finding that fathers who were highly involved during the marriage deal with the pain of losing the daily interaction with their children and their daily parental responsibilities by completely disengaging over time and that disengaged fathers tend to be those who were highly involved during the marriage); Seltzer, supra note 84, at 80 ("By avoiding contact, some fathers face fewer reminders of their 'lost' children.").

${ }^{286}$ For example, one father who had chosen not to see his child for nine months expressed:

Every time I pulled up to the driveway to let him off, it was like part of me was dying all over again. I could barely keep myself together long enough to give him a hug good-bye. I knew it wasn't good for him to leave seeing me so visibly upset every time. He would open the door, step out of the car, and I would feel as if I would never see him again. He would walk up the sidewalk and a sense of grief would utterly overcome me. It would take me several days to pull myself together enough to even function at work. I'd have to keep his bedroom door closed; I couldn't bear to see his empty room. I had to break it off totally just to survive. The visits themselves were terrible because I had this constant unease, knowing what was coming.

ARENDELL, supra note 84, at 154. Another father stated, "[b]y the time your coat is off, you're not interacting, you're worrying about when they'll go back. You're tearing your heart and guts out saying, 'You're only going to see them for a few hours.' ... You're disoriented and it's hard to interact with your children that way." Id. at 154-55. 
their intensity, their insufficiency-and the father's sense of guilt and anger over the divorce also inhibit consistent and frequent visitation." ${ }^{287}$ Although disengaging generally did not alleviate nonresidential fathers' sense of loss and depression, ${ }^{288}$ one study found that within two years of divorce, many fathers who found seeing their children "intermittently" unbearable were coping by seeing them infrequently. ${ }^{289}$ Unlike mothers, many fathers feel they are entitled to distance themselves from their children if necessary to minimize the pain of not residing with them or parenting them every day. ${ }^{290}$ Because there is not yet a norm of involved post-divorce fatherhood, it is less difficult socially, ${ }^{291}$ although no less painful emotionally, for fathers to walk away from their children if seeing them only occasionally causes them unbearable anguish.

\section{Conflict With the Child's Mother}

Nonresidential fathers' relationships with their children's mothers play a large and sometimes determinative role in fathers' level of involvement in their children's upbringing. ${ }^{292}$ Indeed, the relationship between the parents, rather than the level of paternal involvement or strength of the father-child bond during the marriage, is the strongest predictor of frequent paternal contact after divorce. ${ }^{293}$ Even the small

${ }^{287}$ Fox \& Blanton, supra note 101, at 264.

288 See E. Mavis Hetherington et al., Divorced Fathers, 25 FAM. COORDINATOR 417, 422 (1976) (noting that these fathers often felt "shut out, rootless and at loose ends"); see also Dowd, supra note 89, at 523-24 (disagreeing with the notion that fatherhood is unimportant to most fathers and that fathers do not suffer when they lose contact with their children); Kruk, supra note 13, at 19 (concluding that noncustodial fathers who were highly involved with and attached to their children during the marriage suffered high levels of distress several years after the divorce as a result of the actual or feared loss of their children).

${ }^{289}$ Folberg \& Graham, supra note 283, at 555.

290 See ARENDELL, supra note 84, at 144 (reporting that some fathers in the study believed that the emotional costs of maintaining a relationship with their children would likely drive them away in the near future).

${ }^{291}$ See supra text accompanying notes 79-94 (describing how there is no social norm of fathers remaining involved in parenting after divorce).

${ }^{292}$ See ARENDELL, supra note 84, at 145 ("[F] ormer spousal conflict was the primary explanation for fathers' parental disengagement....”). In fact, one study showed that sixty-four percent of fathers who chose to see their children infrequently or not at all cited problems with their former spouses as the main reason for this lack of contact. Greif, supra note 126, at 79.

${ }^{293}$ See Dowd, supra note 89, at 525 (finding the father's relationship with his exwife to be of paramount importance); McKenry et al., supra note 21, at 307 (arguing 
percentage of fathers who claim to be satisfied having little or no contact with their children admit, upon further probing, that they blame their children's mother for the lack of contact. ${ }^{294}$ Thus, they do not perceive their lack of involvement as voluntary, but rather as coerced. $^{295}$

Fathers' petitions to enforce visitation rights are relatively common, second only to child support complaints. ${ }^{296}$ Some researchers estimate that one-third to one-half of residential mothers interfere with visitation ${ }^{297}$ by "forgetting" appointments, insisting on rigid schedules, denying visitation if the father's girlfriend will be present, relocating without notifying the father, making the children feel guilty for seeing their father, and disparaging the father in front of the children. $^{298}$

that "fathers' feelings about the former spouse appear to be a more influential predictor of frequency of visitation than fathers' feelings about their children").

${ }^{294}$ Greif, supra note 126, at 82 (finding that most of the fathers without contact "are unhappy with their situation"). Although fourteen percent of fathers stated that they were content with their current level of contact and did not desire more contact with their children, sixty-four percent of those fathers blamed the other parent for the low level of contact. Id. at 78-79.

${ }^{295}$ For example, one father stated that the mother had "worked very hard for three years" to successfully alienate the children from him. Id. at 80. Another father who had not seen his teenage children in three years wrote that their mother had "brainwashed" them to have no contact with him. Id. These fathers' statements that they do not desire increased contact with their children are colored by their statements that contact ceased as a result of the custodial mother's interference with the relationship. Thus, the percentage of fathers who want no contact with their children is likely less than the reported fourteen percent.

${ }^{296}$ Fox \& Blanton, supra note 101, at 262.

297 See PARKE, supra note 126, at 195-96 (1981) (finding that "between 25 and 50 percent of mothers may interfere with or make visitation more difficult" and "nearly 40 percent" of mothers have refused visitation and their decision was not influenced by the child's "health, safety, or wishes"); Czapanskiy, supra note 115, at 1449 (noting that custodial mothers deny fathers visitation in about twenty to twenty-five percent of all cases); Loewen, supra note 105, at 195, 202 (citing studies pertaining to the mother's role in visitation). In one study of 820 college students whose parents had been divorced on average for ten years, the students reported that their mothers were generally opposed to them having more time with their fathers, although forty-eight percent of the children wanted substantially more time with their fathers. William V. Fabricius \& Jeff A. Hall, Young Adults' Perspectives on Divorce: Living Arrangements, 38 FAM. \& CONCILIATION CTS. REV. 446, 446, 451-52 (2000).

${ }^{298}$ See, e.g., Schutz v. Schutz, 581 So. 2d 1290, 1291-92 (Fla. 1991) (finding the custodial mother relocated with the children repeatedly without notifying the father and "brainwashed" the children into "hat[ing], despis[ing] and fear[ing]" their father); WALLERSTEIN \& KELLY, supra note 21, at 125 (describing how former wives have used "a thousand mischievous, mostly petty, devices designed to humiliate the visiting parent and to deprecate him in the eyes of his children"). Sometimes mothers interfere with visitation because the father has not paid child support. See Furstenberg, supra 
Currently, when mothers interfere with visitation there is little nonresidential fathers can do to enforce their rights to see their children without incurring significant expenses, both financial and emotional. Although many states have criminalized such interference ${ }^{299}$ and courts have held mothers who interfere with visitation in contempt and imprisoned them until they agreed to comply with the visitation order, ${ }^{300}$ this is rare, as most parents do not wish to send their children's other parent to jail. ${ }^{301}$ In extreme cases, courts have deprived mothers of child support payments until they comply with visitation orders, ${ }^{302}$ but most judges have refused to impose this sanction, in part, because it punishes the children. ${ }^{303}$ Courts have also been reluctant to impose fines for interfering with visitation because they may force divorced mothers, who may be struggling financially, to use

note 15, at 664 (noting that mothers discouraged or prevented fathers' contact with children especially when dissatisfied with the level of child support paid). Although mothers' attempts to motivate fathers to pay support by making access to the children contingent on payment is understandable, the law treats child support and visitation separately. One is not dependent on the other.

${ }^{299}$ See, e.g., 720 ILl. COMP. STAT. ANN. 5/10-5.5 (West 2002) (making "unlawful visitation interference" a petty offense); IND. CODE ANN. § 35-42-3-4 (West 1998) (criminalizing violations of custody orders by hiding, kidnapping, or taking a child out of state); MO. ANN. STAT. $§ 452.400 .7$ (West 2003) (providing for application of court's powers of contempt when a parent interferes with custody).

${ }^{300}$ See, e.g., Morgan v. Foretich, 528 A.2d 425, 428-29 (D.C. 1987) (upholding a judgment of civil contempt when the mother refused to comply with a visitation order); Smith v. Smith, 434 N.E.2d 749, 753 (Ohio Ct. App. 1980) (affirming as not grossly excessive a five-day civil contempt sentence against a mother for interfering with visitation); LEVING, supra note 112, at 7 ("Sanctions imposed to punish violation of a family court's visitation orders can include fines, forfeiture of child support, and sometimes incarceration.").

${ }^{301}$ Thus, many fathers fail to seek the courts' aid in enforcing visitation. However, some fathers claim that when they have sought to enforce visitation, they have not received any assistance. For example, although California has criminalized a custodial parent's interference with visitation, when fathers have asked the police to enforce visitation, they have been told, "[t]his is a civil matter. Go talk to your attorney." McCant, supra note 79 , at 138 . When they go to the district attorney's office, they are told that the office lacks the resources to assist them in enforcing visitation. Id.

${ }^{302}$ Sipos v. Sipos, 425 N.Y.S.2d 414, 415 (App. Div. 1980); cf. Hecht v. Hecht, 635 N.Y.S.2d 280, 281 (App. Div. 1995) (reversing suspension of child support because the interference with visitation did not constitute "deliberate frustration").

${ }^{303}$ See Kemp v. Kemp, 399 A.2d 923, 930 (Md. Ct. Spec. App. 1979) (finding error in chancellor's cancellation of child support payments because visitation and support are not "mutually dependent" terms), rev'd on other grounds, 411 A.2d 1028 (Md. 1980); State ex rel. Southwell v. Chamberland, 361 N.W.2d 814, 817 (Minn. 1985) ("[W] rongful deprivation of visitation rights will not affect the obligation of child support.”). 
child support money to pay the fines. ${ }^{304}$ If all else fails, courts can take residential custody away from a parent who continually interferes with visitation and grant residential custody to the other parent. ${ }^{305}$ However, courts are hesitant to remove children from a residential arrangement to which they have become accustomed, unless there is a risk of physical or emotional harm. ${ }^{306}$

Courts' apparent failure to enforce visitation has led many fathers to believe that the law does not value their relationships with their children outside of their financial contributions. Although government agencies are responsible for enforcement of child support orders ${ }^{307}$ there is no similar streamlined enforcement mechanism for visitation. When mothers interfere with visitation, fathers frequently must hire attorneys to assist them in enforcing their visitation rights. ${ }^{308}$ As a result of the difficulties and expenses of enforcing visitation, some fathers stop trying. ${ }^{309}$

Fathers' stated reasons for disengaging from their children are many and complex, encompassing legal, social, cultural, and emotional factors. As shown below, legal mechanisms can influence most, if not all, of these factors and encourage fathers to remain involved after divorce.

${ }^{304}$ See supra note 23 and accompanying text (showing that the standard of living of residential mothers and their children decreases after divorce).

${ }^{305}$ See Egle v. Egle, 715 F.2d 999, 1016-17 (5th Cir. 1983) (holding that interference with visitation may be grounds for changing custody).

${ }^{306}$ For example, one father found his daughter two years after the mother took the child out of the state in violation of the joint legal custody order. ARENDELL, supra note 84, at 87. Although the judge found that the mother was unfit and had moved the children from place to place, the judge refused to modify custody in favor of the father because the children would be upset if taken away from their mother. The judge agreed that in the long term, the children would be better off with the father, but in the short term, they would be too distraught. Id.

${ }^{307}$ See Laura Morgan, What Every Parent Must Know About Child Support, FAM. ADVOC., Summer 2003, at 22, 22-24 (explaining the process of obtaining and enforcing child support).

${ }^{308}$ A father can file a petition pro se, but as with any legal matter, legal representation is generally recommended. Some states authorize an award of attorneys' fees for legal expenses incurred in enforcing visitation. See ALA. CODE §§ 30-3-168 (Supp. 2003) (authorizing award of attorney fees and costs to fathers enforcing visitation rights); MO. ANN. STAT. $§ 452.377$ (West 2003) (same); MINN. STAT. § 518.1751 (2004) (same). But since many residential mothers lack any assets from which to pay the judgment, fees are frequently impossible to recover.

${ }^{309}$ See Loewen, supra note 105, at 202 (noting that when the relationship between parents is hostile, a visitation father will "withdraw from this unequal power relationship"). 


\section{Changing the Norm: EnCouraging PATERNAL ENGAGEMENT}

In Part III, I focused on the many reasons why nonresidential fathers disengage from their children after divorce. My focus, however, is not limited to this area. As many scholars have noted, fathers' reasons for their lack of involvement in their children's upbringing must be examined with some skepticism. Given that the majority of married fathers' involvement with their children is limited, ${ }^{310}$ we should be at least somewhat doubtful of fathers' sudden claim of interest in the children once the marriage ends. Yet traditional fathers (those who did little of the day-to-day child rearing during the marriage) are not the only ones who are abandoning their children at alarming rates. Modern nurturing fathers (those who have proven their commitment to their children during the marriage) are also disengaging at high rates and at a great emotional cost to both them and their children. ${ }^{311}$ I argue that legal and social forces may be pushing away those fathers who, by all historical indicators, one might expect to remain involved in their children's lives. In the end, fathers' stated reasons for disengaging may not be as important as the sociolegal forces that discourage paternal involvement and fail to provide incentives for them to remain involved. Regardless of fathers' reasons for disengaging, children generally benefit from their fathers' involvement ${ }^{312}$ and thus, public policy should encourage paternal involvement. Thus, my general focus is less on the reasons fathers disengage and more on how the law can encourage and even gently pressure paternal engagement when necessary.

In this Part, I argue that, in the same manner that the law has influenced social norms of marital commitment and parental financial responsibility, ${ }^{313}$ it can facilitate a social norm of paternal involvement after divorce by adopting a presumption of joint legal custody and requiring that nonresidential parents participate in their children's up-

${ }^{310}$ See supra note 11 and sources cited (documenting the continued lack of parental involvement among married fathers).

${ }^{311}$ See supra note 126 and accompanying text (discussing the connection between parental involvement during the marriage and parental disengagement post-divorce).

${ }^{312}$ See discussion supra Part II.C on the wealth of evidence that children's wellbeing is affected by parental involvement post-divorce.

313 See supra Part I for a summary of Professor Scott's evidence of the influence of law on social norms in the marital and parenting contexts. 
bringing. ${ }^{314}$ Drawing on norms theorists' analyses of how social norms arise, I argue that even with minimal or no legal enforcement, these legal reforms can trigger a norm of paternal involvement after divorce.

\section{A. Presumption of Joint Legal Custody}

As discussed in Part II.A, when parents divorce, current social norms dictate that mothers have custody and fathers have the right to visitation. Although an increasing number of fathers are seeking and obtaining sole or joint custody (either by court order or agreement), society still assumes that mothers without residential custody must be unfit. $^{315}$ The societal pressure on women to have residential custody is so great that mothers who may not want custody may seek it to avoid social stigma. ${ }^{316}$ On the other hand, fathers who want custody may not seek it for reasons discussed herein ${ }^{317}$ and may fail to exercise visitation rights because they have internalized the message that their role after divorce is primarily economic. They also may not realize the importance of their presence and involvement to their children's wellbeing. ${ }^{318}$ By adopting a presumption of joint legal custody, the law can signal to fathers that they are important to their children for more than just their financial contributions. Fathers who believe they can

${ }^{314}$ I am not arguing that the law can make every nonresidential father into an incredibly involved father-one who assumes half of the child-rearing responsibilities. Given that most married couples do not share co-equal parenting, see supra note 11, it would be unrealistic to expect the law to facilitate that result when the child no longer lives with both parents. What I seek is some level of paternal involvement after divorce sufficient to maintain a significant parental relationship and to convey to children that they still have two parents after divorce.

${ }^{315}$ See supra note 81 and accompanying text (noting that society presumes that nonresidential mothers must be unfit).

${ }^{316}$ See Brinig \& Buckley, supra note 42, at 401 ("When joint custody was uncommon, fathers did not seek custody, and women were regarded as poor mothers if they did not do so.”); SusAn Anderson-Khlief, Divorced But Not Disastrous 87, 90 (1981) ("[W] omen are under a great deal of pressure to take custody after divorce. . . It is, indeed, possible that most women feel they have "no choice.").

${ }^{317}$ See supra Part III.B (hypothesizing that fathers' perceptions of gender bias discourages their parental involvement after divorce to a greater extent than actual bias does).

318 See supra note 105 and accompanying text (describing some misconceptions commonly held by fathers regarding their influence on their children). 
play important roles and influence their children's lives are more likely to be involved in their upbringing. ${ }^{319}$

As with sole custody, courts decide whether to award joint custody based on the best interests of the child standard. ${ }^{320}$ Joint custody embodies two components-legal custody and physical/residential custody. ${ }^{321}$ When parents have joint legal custody, they share legal authority to make major decisions concerning the child's welfare, such as educational, religious, and medical decisions. ${ }^{322}$ However, joint legal custody does not necessarily affect the child's physical custody or residence. Thus, the court may issue a joint legal custody award, but designate one parent, usually the mother, the sole residential custodian or primary residential parent. ${ }^{323}$ The child resides with the primary residential parent who is responsible for the "minor dayto-day decisions," ${ }^{324}$ and the other parent, in effect, has visitation.

In the twenty-five years since California adopted the first joint custody statute in the country, joint legal custody has become quite common. ${ }^{325}$ Indeed, almost half the states have adopted a preference

319 See McKenry et al., supra note 21, at 312 (finding that fathers' perceived satisfaction and influence on their children's lives is a statistically significant factor predicting level of physical involvement).

${ }^{320}$ See, e.g., CAL. FAM. CODE $\$ 3020$ (West 2004) (requiring the choice of joint, sole, or other custody arrangements to be made in the best interests of the child); N.J. STAT. ANN. § 9:2-4 (West 2002) (same); Taylor v. Taylor, 508 A.2d 964, 969 (Md. 1986) (same); UTAH CODE ANN. § 30-3-10.2(1) (Supp. 2004) (stating that joint legal or joint physical custody may awarded if it is in the best interests of the child).

${ }^{321}$ See Taylor, 508 A.2d at 967 ("Embraced within the meaning of 'custody' are the concepts of 'legal' and 'physical' custody."); PARKE, supra note 126, at 213 (noting that "joint custody can take two main forms").

${ }^{322}$ See Taylor, 508 A.2d at 967 (defining legal custody as "the right and obligation to make long range decisions [on] ... matters of major significance concerning the child's life and welfare"); Beck v. Beck, 432 A.2d 63, 66 (N.J. 1981) (finding that where the parents have joint legal custody, "the legal authority and responsibility for making 'major' decisions regarding the child's welfare-is shared at all times by both parents").

323 See, e.g., UTAH CODE ANN. § 30-3-10.1(1)(c)-(e) (Supp. 2004) (providing that joint legal custody does not determine the child's physical custody and the court may "specify[] one parent as the primary caretaker and one home as the primary residence of the child"); Homer H. Clark, JR. \& ANn LaQUer Estin, CASES AND Problems in DOMESTIC RELATIONS 1002 (6th ed. 2000) (describing trends in custody awards).

${ }^{324}$ Beck, 432 A.2d at 66.

325 See MACCOBY \& MNOOKIN, supra note 13, at 106-08 (studying divorced families in California and finding that nearly eighty percent had joint legal custody); Nord \& Zill, supra note 15 ("[J] ust over 1 million [persons] have joint legal only arrangements with one of the parents, usually the mother, having physical custody."). Joint physical custody is still rare, however. See Pascale v. Pascale, 660 A.2d 485, 491-92 (N.J. 1995) (declaring that joint physical custody is rare in New Jersey and citing sources that show 
or presumption of joint legal custody, ${ }^{326}$ although in many states the preference or presumption applies only if the parents agree. ${ }^{327}$ In the remaining states, joint custody is merely an option and in some of these states, courts can order joint custody only if both parents agree; thus one parent can defeat joint custody merely by objecting to it. ${ }^{328}$

the same is true in Massachusetts, Vermont, and New Hampshire); Nord \& Zill, supra note 15 ("Of the 1.3 million persons with joint custody arrangements .... [only $262,000]$ report joint legal and physical arrangements.").

${ }^{326}$ Twenty-four states and the District of Columbia have presumptions or preferences for joint legal custody. See, e.g., D.C. CODE ANN. § 16-914(a)(2) (2001) (creating a rebuttable presumption of joint custody); FLA. STAT. ANN. § 61.13(2) (b) (2) (West 2004) (stating that there is a presumption of joint custody unless it would be detrimental to the child); IDAHO CODE $§ 32-717 B(4)$ (Michie 1996) (same as D.C. statute); IOWA CODE ANN. \$ 598.41.2 (West 2001) (requiring a court to consider joint custody if either parent requests it, and if the court does not grant joint custody it must cite clear and convincing evidence that joint custody is unreasonable and not in the child's best interests); Minn. STAT. ANN. §518.17 (West 1990) (same as Iowa statute); N.H. Rev. StaT. ANN. § 458.17 (Supp. 2003) (same as D.C. statute); N.M. STAT. ANN. § 40-4-9.1 (Michie 1999) (same as D.C. statute); TEX. FAM. CODE ANN. § 153.131 (Vernon 2002) (creating a rebuttable presumption of joint appointment of both parents as conservators of the child); COLO. REV. STAT. § 14-10-124(1) (2004) (encouraging "parents to share the rights and responsibilities of child-rearing"); KAN. STAT. ANN. $\$ 60$ 1610(4) (A) (Supp. 2003) (suggesting joint custody as the preferred custody arrangement); MO. ANN. STAT. \$ 452.375.4 (West 2003) (citing the state's policy of encouraging child contact with both parents after divorce); OR. REV. STAT. § 107.105(1)(a) (Supp. II 1998) (same).

327 See ALA. CODE $§ 30-3-152$ (c) (1998) (presuming joint custody to be in a child's best interest if it is requested by both parents); CONN. GEN. STAT. ANN. $§ 46 \mathrm{~b}-56 \mathrm{a}$ (b) w(West 2004) (same); LA. CIV. Code ANN. art. 132 (West Supp. 2005) (same); Me. REV. STAT. ANN. tit. 19A, § 1653.2.D.1 (Supp. 2003) (same); MiCH. COMP. LAws ANN. § 722.26a(2) (West 2002) (same); Miss. CoDE ANN. § 93-5-24(4) (1999 \& Supp. 2003) (same); Nev. Rev. Stat. ANN. 125.490.1 (Michie 2004) (same); TenN. Code ANN. § 36-6-101(2) (A) (2001) (same); see also Smith, supra note 118, at 41 (stating that eleven states and D.C. have a "general presumption in favor of joint custody" while twelve other states have a "preference" for joint custody if both parents agree); $c f$. CAL. FAM. CODE $\$ 3080$ (West 2004) (describing California statute that creates a presumption in favor of joint custody where parents cannot agree on a custody plan). In addition, according to Professor Bartlett:

[Although $\mathrm{t}$ ] here is a widespread belief that the law has become highly favorable to joint custody. . . . [and m] any states express the policy goal that there be frequent and continuing contact between the child and both parents after divorce. . . . few states actually follow up that policy commitment with a meaningful presumption in favor of joint custody. Those states generally represented as having a presumption in favor of joint custody apply the presumption only when the parents agree to it, which is a presumption in favor of parental agreement, not joint custody.

Katharine T. Bartlett, U.S. Custody Law and Trends in the Context of the ALI Principles of the Law of Family Dissolution, 10 VA. J. SOC. POL.'Y \& L. 5, 21-22 (2002) (footnote omitted).

${ }^{328}$ E.g., OR. REV. STAT. § 107.169(3) (1990) ("The court shall not order joint custody, unless both parents agree ...."); UTAH CODE ANN. § 30-3-10.2(1) (1998 \& Supp. 
Even if a statute does not require both parents' consent to joint legal custody, in practice, most courts award it only if both parents agree. ${ }^{329}$ Although an increasing number of fathers seek joint legal custody, many mothers object, thereby defeating the possibility of a joint legal custody award in many jurisdictions. Some women object to joint custody for good reasons-for example, the father is emotionally and/or physically abusive. ${ }^{330}$ Yet others object because they want to punish their former husbands for ending the marriage, for their infidelity, or for other reasons having little to do with the children's best interests. $^{331}$ Others have been advised by friends or family members not to grant the father more than the traditional every-other-weekend visitation. $^{332}$

One parent should not have the power to veto joint custody without evidence that it would be detrimental to the child's best interests. A true presumption of joint legal custody would limit one parent's ability to veto joint legal custody for the wrong reasons. Under my proposal, only if the parent opposed to sharing legal custody with the other parent rebuts the presumption by showing that the other parent is unfit would the court consider another custodial arrangement, e.g., sole maternal or sole paternal custody. Either parent, a law guardian, a guardian ad litem, a social worker, or a mental health expert could submit evidence that joint legal custody would be detrimental to the child. For example, evidence of domestic violence, mental illness, alcohol or drug abuse, or historical lack of parental interest in the child would be highly relevant and possibly determinative. ${ }^{333}$ A presump-

2004) (requiring a parenting plan for joint legal custody); VT. STAT. ANN. tit. 15, § 665 (a) (2002) ("When the parents cannot agree ... [to joint custody,] the court shall award parental rights and responsibilities primarily or solely to one parent.").

${ }^{329}$ See In re Marriage of Drummond, 509 N.E.2d 707, 712-13 (Ill. App. Ct. 1987) ("Since joint custody requires extensive contact and intensive communication, it cannot work between belligerent parents."); Braiman v. Braiman, 378 N.E.2d 1019, 1021 (N.Y. 1978) (holding that joint custody award is not appropriate where the parents are "embattled and embittered"). But see Beck v. Beck, 432 A.2d 63, 71 (N.J. 1981) (holding that the parents' opposition to joint custody does not preclude the court from ordering it); $c f$. Squires v. Squires, 854 S.W.2d 765, 775 (Ky. 1993) (appealing to the legislature to change the law and make parental agreement a prerequisite for joint custody).

${ }^{330}$ Kelly, supra note 81, at 769.

${ }^{331} I d$.

${ }^{332} I d$.

${ }^{333}$ Because "batterers are more likely than ... nonbattering fathers to seek custody," Lundy Bancroft \& JAy G. Silverman, The Batterer as PARENT: AdDREssing THE IMPACT OF DOMESTIC VIOLENCE ON FAMILY DyNAMICS 113 (2002), I would not recommend joint legal custody when there is evidence of domestic violence. Many courts 
tion of joint legal custody would decrease the likelihood that a parent would object to sharing legal custody with the other parent, absent evidence of the other parent's unfitness. Thus, the majority of parents might agree to joint legal custody ${ }^{334}$ and drastically reduce custody litigation. ${ }^{335}$

Some feminists have opposed joint legal custody, fearing that fathers who do not really want legal custody will seek it (or threaten to seek it) with the intention of coercing their former wives into accepting smaller property settlements than they are entitled to under the law. They argue that mothers' fear of sharing custody with fathers who use children as bargaining chips gives fathers power in obtaining more favorable property settlements. ${ }^{336}$ There is no empirical evidence suggesting that a significant number of fathers seek joint cus-

agree. See Borchgrevink v. Borchgrevink, 941 P.2d 132, 140-41 (Alaska 1997) (affirming grant of legal and physical custody to mother where sufficient evidence of domestic violence was present); Knock v. Knock, 621 A.2d 267, 273-74 (Conn. 1993) (stating that evidence of spousal abuse can influence court to award sole custody to nonabusive parent). But see Michael E. Lamb, Placing Children's Interests First: Developmentally Appropriate Parenting Plans, 10 VA. J. SOC. POL'Y \& L. 98, 116-18 (2002) (discussing studies suggesting "that minor or isolated instances of domestic violence should not affect decisions regarding custody and visitation").

${ }^{334}$ Although courts generally approve parents' agreements concerning custody, courts have an obligation to evaluate such agreements and must modify or overrule parents' proposed arrangements when they are not in the children's best interests. See Am. LaW InSt., Principles of the LaW of Family Dissolution: Analysis and RECOMMENDATIONS $\S 2.06 \mathrm{cmt}$. a (2002) ("The law in most jurisdictions grants courts ... the authority to review a private agreement at divorce to determine whether it serves the child's interests.").

${ }^{335}$ See Schepard, supra note 131, at 716 (arguing that if the law "favors joint custody unless one of the parents is 'unfit,' parents would have far less incentive to oppose joint custody" because of the strong likelihood of such a ruling in court). A presumption of joint legal custody would also create greater certainty in custody disputes and provide a disincentive to litigate. Id. at 733 .

${ }^{336}$ See, e.g., Lenore J. Weitzman, The Divorce Revolution: The UneXPected SOCIAL AND ECONOMIC CONSEQUENCES FOR WOMEN AND CHILDREN IN AMERICA 310-18 (1985) (discussing male/female differences in custody and support negotiations); Richard Neely, The Primary Caretaker Parent Rule: Child Custody and the Dynamics of Greed, 3 YALE L. \& POL'Y REV. 168, 179 (1984) ("The everyday occurrence of children being traded for money should be sufficient in and of itself to prompt a reëvaluation [sic] of a system that turns custody awards into bargaining chips.”); Singer \& Reynolds, supra note 135, at 515-16 ("[D]ivorcing fathers routinely and successfully use the threat of a custody battle to extract damaging financial concessions from their ex-wives during divorce negotiations."). Of course, a preference for sole custody may give the parent likely to be awarded custody an incentive to veto joint custody in return for a higher property settlement. See Schepard, supra note 131, at 715-16 (discussing the "complex interplay between custody and financial issues in divorce settlement negotiations"). 
tody for leverage in property settlement negotiations. ${ }^{337}$ But even if this phenomenon did exist, a presumption of joint legal custody would in fact reduce the likelihood that fathers would use the threat of joint custody as a bargaining chip. Under my proposal, courts would presume that joint legal custody is in the children's best interests even if only one parent is seeking custody and the other parent does not object. Thus, a parent who threatens to seek custody for the purpose of negotiating a more favorable property settlement would gain little leverage in the bargaining. In other words, a father would not be able to say to the mother, "I won't seek custody if you agree not to seek alimony" because whether he seeks custody or not, the presumption of joint legal custody would still apply.

It would not be in children's best interests (nor would it be possible) for the law to force legal custody on a parent who is adamantly opposed to it. Thus, a parent who does not want joint legal custody and favors sole custody residing in the other parent must be able to rebut the presumption of joint legal custody. But merely expressing lack of interest in legal custody would not suffice.

Parents wishing to avoid the responsibilities of parenting would have to participate in what I call a "Refusal of Parental Responsibilities" hearing, which would be similar to a plea allocution in criminal cases. To illustrate, the court would inform parents rejecting legal custody that they have a right to joint legal custody, that the law has a preference for joint legal custody, that research shows that children benefit from both parents' involvement in their upbringing, that children want both parents to be involved in their upbringing, that an order of sole custody shows that the noncustodial parent conceded unfitness or was found unfit by the court, and that the parents are legally bound to pay child support even if the other parent has sole custody. The court would also ask the parent to state on the record his reasons for rejecting the children. While this would not be a formal plea hearing, the inquiry would, in effect, ask a parent to admit that he is a "bad" parent in order to avoid receiving joint custody. Parents who fail to attend the Refusal of Parental Responsibilities hearing would be found unfit by default. As shown below, over time, fewer parents would refuse to assume the duties of parenthood because of the social stigma-parental unfitness - that would attach to parents lacking legal custody. Further, parents would be unlikely to refuse joint legal cus-

337 See MACCOBY \& MNOOKIN, supra note 13, at 156 (studying divorced families in California and finding "no statistically persuasive evidence that those mothers who experienced more legal conflict had to give up support to win the custody they wanted"). 
tody in exchange for a greater share of the marital property for that same reason. Thus, as social norms become more powerful, there would be fewer Refusal of Parental Responsibilities hearings and cases of unfitness by default.

\section{Symbolic Function and Paternal Involvement}

Although a number of studies have found that joint legal custody leads to greater paternal involvement, ${ }^{338}$ others have found that fathers with joint legal custody are no more likely than sole maternal custody fathers to see their children frequently or to participate in either day-to-day or major decisions about their children's upbringing.

Given the inconclusive evidence that joint legal custody leads to greater paternal engagement, why should courts adopt a presumption of joint legal custody? First and foremost, a presumption of joint legal custody serves an important symbolic function. Even if fathers with joint legal custody do not spend more time with their children than sole maternal custody fathers, a presumption of joint legal custody signals to fathers that the law and society respect their rights and responsibilities as parents and sends a message that fathers are important and should be involved in their children's upbringing. ${ }^{340}$ Some social scientists have recommended a presumption of joint legal custody because it affirms that both mothers and fathers have rights and responsibilities vis-à-vis their children after divorce. ${ }^{341}$ Thus, the pri-

${ }^{338}$ See, e.g., Bahr et al., supra note 208, at 258 (finding that joint legal custody increased fathers' involvement with their children (citing Madonna E. Bowman \& Constance R. Ahrons, Impact of Legal Custody Status on Fathers' Parenting Postdivorce, $47 \mathrm{~J}$. MARRIAGE \& FAM. 481 (1985))); Judith A. Seltzer, Father by Law: Effects of Joint Legal Custody on Nonresident Fathers' Involvement with Children, 35 DEMOGRAPHY 135, 135, 14144 (1998) (reporting that, after "controlling for socioeconomic status and the quality of the relationship before separation, fathers with joint legal custody see their children more frequently and have more overnight visits than noncustodial fathers"-in a national survey, thirty-nine percent of fathers with joint legal custody saw their children at least once a week as opposed to twenty-four percent of fathers in other custody arrangements, and spent fourteen more overnights per year with their children than non-joint custody fathers); see also Seltzer, supra, at 135 (“[T] hese findings support the view that joint legal custody may encourage some aspects of paternal involvement after divorce.").

339 See, e.g., FurStenberG \& ChERLIN, supra note 23, at 74 (finding no definitive link as of 1991); PARKE, supra note 126, at 215 (same).

${ }^{340}$ FURSTENBERG \& CHERLIN, supra note 23, at 113.

${ }^{341}$ See MACCOBY \& MNOOKIN, supra note 13, at 289 (noting that joint legal custody "affirm[s] the idea that in the eyes of the law fathers should play a continuing role in their children's lives"); PARKE, supra note 126, at 217 (noting that the symbolic value 
mary benefit of joint legal custody may be its symbolic value. As noted in Part II.A, fathers receive ambiguous messages about their parental responsibilities after divorce. A presumption of joint legal custody would clarify that paternal responsibilities entail more than just financial support. ${ }^{342}$ "By clarifying that divorced fathers are 'by law' still fathers, parents' negotiations about fathers' participation in childrearing after divorce may shift from trying to resolve whether fathers will be involved in childrearing to how fathers will be involved." ${ }^{343}$

As discussed above, attorneys are key actors in reinforcing perceptions of bias against fathers in custody disputes. ${ }^{344}$ Attorneys effectively discourage fathers from seeking a greater role in their children's upbringing by questioning fathers' motives for wanting to be more involved in their children's lives and advising them that their likelihood of obtaining sole or joint custody is slim. ${ }^{345}$ Attorneys further foster the perception that the law does not consider fathers' noneconomic contributions important by advising fathers not to seek more than the standard biweekly visitation schedule. A presumption of joint legal custody would necessarily change the advice that attorneys give fathers since it would be misleading for them to advise fathers that their likelihood of obtaining joint legal custody is low. Attorneys might also risk malpractice suits if they advise fathers not to seek joint custody when they are likely to succeed. In other words, attorneys would have to notify fathers that the law favors joint custody. As a result, fathers who are currently dissuaded from seeking custody by their attorneys' advice might be more proactive in securing increased parenting time with their children.

If the law is to signal to nonresidential fathers that they are as important as residential mothers, courts must make it easier and less costly to enforce visitation. Courts must be willing to hold residential parents in contempt for interfering with visitation without justification. ${ }^{346}$ Courts must also be willing to modify children's residential arrangements if the residential parent repeatedly interferes with the

signals to fathers that they have "rights and responsibilities" and to children that the fathers are still part of the family).

342 'The status of legal custodian may reduce ambiguity in fathers' and mothers' expectations about nonresident fathers' rights and responsibilities to children after divorce." Seltzer, supra note 338, at 145.

${ }^{343} I d$.

${ }^{344}$ See supra Part III.B for a discussion of gender bias in custody disputes.

${ }^{345}$ See supra notes 251-52 and accompanying text.

${ }^{346}$ A mother's allegation of physical or sexual abuse would constitute good reason. A father's failure to pay child support would not. 
nonresidential parent's relationship with the children. Some states have found creative ways of enforcing access, for example, by providing makeup visitation to compensate nonresidential parents for lost parenting time caused by the residential parents' interference. ${ }^{347}$ Suspending driving privileges and professional licenses of residential parents who repeatedly interfere with visitation or posting their names in the family court waiting area are other possible remedies. Courts have also required that residential parents who have interfered with visitation post bond with the court to ensure compliance with visitation. ${ }^{348}$ Other states have authorized attorney's fee awards to parents for their expenses in enforcing visitation. ${ }^{349}$ These types of measures signal to nonresidential parents that the law considers them full parents and values their noneconomic contributions to their children.

Some commentators have argued that fathers' lack of involvement with their children during the marriage stems, in part, from their fear that in the event of divorce "[they] will lose access to [their] child[ren]." "350 They contend that fathers distance themselves from their children and do not allow themselves to grow as attached as they otherwise might be if they did not feel a need to guard against the pain of losing them. ${ }^{351}$ As these scholars have noted, a presumption of joint custody may lead fathers to grow more attached to their children during the marriage since they would not fear losing access to them in the event of divorce. ${ }^{352}$ Thus, in addition to serving the symbolic purpose of indicating to divorced fathers that they continue to be parents and bear the same paternal rights and responsibilities as before the separation, a presumption of joint legal custody may lead to greater

347 See, e.g., COLO. REv. STAT. ANN. § 14-10-129.5(2)(d) (West 2003) (authorizing makeup parenting time); MICH. COMP. LAWS ANN. \$ 552.642 (West 2004) (same); NEV. REV. STAT. ANN. 125C.020 (Michie 2004) (same).

${ }_{348}$ See, e.g., Solberg v. Wenker, 163 Cal. App. 3d 475, 480 (Ct. App. 1985) (noting that a bond may be used "to assure compliance with a visitation order").

349 See, e.g., Colo. Rev. STAT. AnN. 14-10-129.5(4) (Lexis 2003) (authorizing attorney's fees). Awarding attorneys' fees to the noncustodial parent may backfire as the custodial parent may have to use child support payments to pay the award.

${ }^{350}$ Brinig \& Buckley, supra note 42 , at 402.

${ }^{351}$ See id. (noting that some fathers fear that they will lose their children after a divorce).

${ }^{352} I d$. ("When divorce is not a final separation, fathers may permit themselves to bond more closely with their children.”). Brinig and Buckley argue that joint custody laws may reduce divorce rates because fathers who do not fear losing access to their children will invest more in them emotionally, which leads to a better marriage and reduces the possibility of divorce. $I d$. 
involvement among married fathers as well, assuming, of course, that they are aware of the presumption. ${ }^{353}$

Joint legal custody by itself may not achieve greater paternal involvement, but it might when coupled with significant child-rearing responsibilities for both parents. Currently, joint legal custody gives nonresidential parents (usually fathers) rights to participate in major child-rearing decisions, but imposes no concomitant responsibilities to provide physical care to their children. Some feminist scholars have opposed joint legal custody, in part, because it gives fathers decision-making authority without imposing responsibility for their children's upbringing. ${ }^{354}$ Instead, children's physical care is most often left to the residential mothers. ${ }^{355}$ The law must impose child-rearing responsibilities on nonresidential fathers just as it does on residential mothers. By changing the notion of post-divorce nonresidential parenting from a right to a responsibility that parents cannot avoid, my proposal would grant both parents decision-making authority, but obligations would attach to that authority. Both parents would be expected to participate in their children's upbringing, spend significant time with them, and participate in their educational development.

One of fathers' major complaints is that visitation does not allow them enough time with their children to enable them to be parents. ${ }^{356}$ Children and mothers similarly complain that nonresidential fathers do not spend enough time with their children. ${ }^{357}$ Indeed, mothers

353 Too many parents are not aware of the laws that apply in the event of a custody dispute; such a lack of knowledge would allow the perception of bias against fathers to flourish even if legal obstacles were removed. I would recommend giving all parents an informational brochure explaining their parental rights and responsibilities, including social science data indicating that paternal involvement benefits children, as they are exiting the hospital after a child's birth in the same manner that an immunization guide is provided. This would not only increase the likelihood that all parents would be aware of their parental responsibilities and help facilitate a norm of involved fatherhood after divorce, but might also facilitate a norm of paternal involvement during the marriage. I thank Sarah Waldeck for this suggestion.

${ }^{354}$ Singer \& Reynolds, supra note 135 , at 502.

355 See Anne Marie Delorey, Joint Legal Custody: A Reversion to Patriachal Power, 3 CAN. J. WOMEN \& L. 33, 39 (1989) (arguing that "[j] oint legal custody does not provide a mechanism to ensure equal sharing of the rights and responsibilities of childrearing," but rather grants "legal decisionmaking power to [both] parents without corresponding responsibility for the physical care of children") (quoted in Kay, supra note 114 , at 37 ).

${ }^{356}$ See supra Part III.C.1 for a discussion of the problems of "vanilla visitation."

357 See, e.g., WALLERSTEIN \& KELLY, supra note 21, at 203 ("Even where there was regular contact with the father, several of [the boys studied] experienced this contact as insufficient to their needs."); Fabricius \& Hall, supra note 297, at 451 (relating the results of a study showing that forty-eight percent of children wanted to spend more 
have sought legal assistance to force fathers to see their children only to be told that visitation is not legally enforceable. ${ }^{358}$ Children need frequent contact with nonresidential parents in order to avoid the Disneyland Daddy syndrome. ${ }^{359}$ Preschool children especially, because of their "immature sense of time and lack of memory for relationships, need contact with each parent several times a week." ${ }^{360}$ Frequent contact is important, but uninterrupted contact is also necessary. When children spend only one evening or weekend with their fathers, fathers feel the need to entertain them and the children expect to be entertained. ${ }^{361}$ If fathers have residential custody for two months during the summer, long weekends, one week during Christmas, one week for spring break, etc., they might be able to develop a more "normal" parent-child relationship as opposed to the Disneyland trip to their father's house. ${ }^{362}$

Because no visitation schedule will accommodate all families, as Professor Schepard has advocated, each parent should be required to "submit a weekly physical custody plan ... that describes parental re-

time with their fathers); supra notes 173-74 (discussing children's desire to see their nonresidential fathers).

${ }^{358}$ See In re Marriage of Mitchell, 745 N.E.2d 167, 172 (Ill. App. 2001) (“[W]hile some courts have upheld the rights of parents to enforce visitation with their children, we are aware of no case that has recognized a reciprocal right of children to enforce visitation with a parent. . . . a court simply cannot order a parent to love his or her children or to maintain a meaningful relationship with them." (citation omitted)); Czapanskiy, supra note 115, at $1450 \mathrm{n} .123$ (citing a letter from the Chief Assistant Friend of the Court for Oakland County, Michigan, stating, "I have had more custodial parents come into my office and ask for my assistance in getting the noncustodial parent, typically the father, to visit the children, than I have had situations of noncustodial parents asking for assistance because of the denial of visitation."); see also UNIF. MARRIAGE \& DIVORCE ACT $§ 407$, 9A U.L.A., cmt., at 398 (1998) ("[T] he judge should never compel the noncustodial parent to visit the child ....").

359 See supra notes 130-32 (discussing Disneyland Daddies); notes 273-75 and accompanying text (describing the difficulties of infrequent visits by noncustodial parents- the "vanilla visitation" schedule).

${ }^{360}$ Kelly, supra note 81 , at 770; see supra note 274 and accompanying text (arguing that children's perception of time differs from that of adults). "Infants and toddlers with a bond to a nurturing father" may need frequent "overnight [visits] together in order to remember who their fathers are." Kelly, supra note 81, at 768.

${ }^{361}$ See supra notes 130-32 and accompanying text (describing how the relationship of noncustodial parents with their children is often more social than parental, particularly if the children are not included in mundane, day-to-day activities).

362 See ARENDELL, supra note 84, at 179 (asserting that shorter and less frequent visits with a nonresidential father are often vacation-like); Kelly, supra note 81 , at 770 (noting that preschoolers are best served by "contact with each parent several times per week"). 
sponsibilities for the child's physical care." ${ }^{363}$ The court would adopt or modify the plan that best provides each parent with enough time to maintain a significant relationship and be actively involved in the children's upbringing. ${ }^{364}$

How can the law motivate nonresidential parents, even those with joint legal custody, to comply with their obligations of frequent and continuing contact with their children if they are not inclined to do so? First, the law must stop treating visitation or parenting time as a right and treat it instead as a legally enforceable duty. Currently, fathers' responsibilities to their children, other than child support, are voluntary. ${ }^{365}$ When fathers fail to pick up their children for an evening or weekend visit, there are no legal or social sanctions, even if such parenting time was part of the custody and visitation order. This must change. Judges can order nonresidential parents to comply with the physical custody plan they helped draft in the same manner they order them to pay a certain amount of child support each month. ${ }^{366}$ In-

${ }^{363}$ Schepard, supra note 131, at 762; see also AM. LAW INST., supra note 334 , § $2.05(1),(5)$ (a) (i) (requiring parenting plans, including "a custodial schedule that designates in which parent's home each minor child will reside on given days of the year").

${ }^{364}$ Another benefit of joint legal custody and significant parenting time is that it might lead to greater rates of child support payment. See Jessica Perason \& Nancy Thoennes, Child Custody and Child Support After Divorce, in JOINT CusTODY AND SHARED PARENTING 185, 199 (Jay Folberg ed., 2d ed. 1991) (finding that, aside from cases in which support was collected through automatic wage withholding, sixty-four percent of mothers with joint legal custody received all of the child support ordered, while only forty-six percent of mothers with sole maternal custody received their full support). Further, because the conflict between residential mothers and nonresidential fathers often involves money-the mother is angry because the father has not paid child support and as a result, denies him access to the children, making him angry-the payment of child support may help reduce conflict between parents. See FURSTENBERG \& CHERLIN, supra note 23, at 60 (discussing fathers withholding support in response to withheld visitation). In high conflict families, this reduction of conflict would allow children to reap the nonpecuniary benefits of their fathers' nurturing.

365 "Men's rights and responsibilities to children may be codified in custody and child support laws, but the role of father for separated and divorced men is largely voluntary." Judith Seltzer \& Yvonne Brandreth, What Fathers Say About Involvement with Children After Separation, in FATHERHOOD: CONTEMPORARY THEORY, RESEARCH, AND SOCIAL POLICY, supra note 4, at 168; see also supra Part II.A (discussing current norms of post-divorce fatherhood as primarily economic).

${ }^{366}$ Some commentators may wonder whether the law can order parents to spend time with their children. Under the doctrine of parens patriae, courts have a legitimate interest in promoting paternal contact if it is in the children's best interests. See Palmore v. Sidoti, 466 U.S. 429, 433 (1984) ("The State, of course, has a duty of the highest order to protect the interests of minor children ....."); Goodridge v. Dep't of Pub. Health, 798 N.E.2d 941, 962 (Mass. 2003) ("Protecting the welfare of children is a paramount State policy.”). Thus, the law can require that a parent be involved in his 
dividuals are more likely to do something if a judge has ordered them to do it as opposed to giving them the right or option of doing it. If parents are ordered to spend Monday and Wednesday evenings with their children, based, in part, on their proposed physical custody plan, they are more likely to comply than if they are just given the option of exercising visitation rights if they so choose. ${ }^{367}$ To illustrate, parents who pay child support pursuant to a court order are more consistent in making the scheduled payments than those who have informally agreed to pay the residential parent child support. ${ }^{368}$

Although court orders mandating that nonresidential fathers parent their children for a certain number of hours per week will likely lead to greater paternal involvement even without legal enforcement, there will always be some parents who will not comply. How can the law force an unwilling parent to spend time with his children? It cannot and should not. Forcing a parent to spend time with his child against the parent's will is unlikely to foster parental involvement or a significant parental relationship with the child. ${ }^{369}$ However, the law can impose public penalties as a means of shaming nonresidential parents into parenting their children. For example, courts can impose a few hours of community service when parents fail to comply with the physical custody order and have made no attempts to make up the time missed. ${ }^{370}$ The purpose of community service would be similar to that of Virginia's policy of "booting" the cars of parents who have not complied with child support orders; it would alert the community that the person sweeping the park wearing a uniform with a photograph of a child is an "emotional deadbeat." ${ }^{, 771}$ Courts could fol-

or her children's upbringing on the ground that parental involvement is necessary to protect the child's emotional well-being. See Czapanskiy, supra note 115, at 1441 ("Whether state intervention into family life is justified ... [as] protecting the mental health of a child or ... [as] promoting generally accepted notions about appropriate family functioning, family law can legitimately express expectations that the child receive whatever benefits are available from contact with two parents.").

${ }^{367}$ Robert Cooter, Do Good Laws Make Good Citizens? An Economic Analysis of Internalized Norms, 86 VA. L. REV. 1577, 1598-1600 (2000) (noting that many individuals obey the law simply because it is the law); Cooter, supra note 31, at 594 ("[C]itizens respect the law and feel obligated to obey it.").

368 ARENDELL, supra note 84, at 89 ("Payment is even more irregular in the absence of formal child support agreements." (citations omitted)).

369 See, e.g., In re Marriage of Mitchell, 745 N.E.2d 167, 172 (Ill. App. Ct. 2001) (noting that forcing a parent who views spending time with the children as a punishment would probably not be in the children's best interests).

${ }^{370}$ I thank Charlie Sullivan for this suggestion of community service.

371 See supra notes 85-90 and accompanying text (discussing "emotional deadbeats"). Sanctioning parents is not a new or radical idea. Nancy Dowd and Karen 
low Virginia's example and boot the cars of parents who have failed to see their children in violation of the parenting plan. They could also impose many of the same public penalties imposed on nonresidential parents who fail to pay child support such as posting on government agency websites the names and photographs of parents who have had no contact with their children for a certain period of time, or posting their names in post offices, family courts, and other public buildings. ${ }^{372}$ Thus, courts could impose "sanctions that are likely to become known and to generate community gossip." ${ }^{373}$ Courts could also require nonresidential parents who fail to pick up their children at the scheduled time to reimburse the residential parents for their time, as some states have done, ${ }^{374}$ or impose minor fines that could be used to create billboards asking, "Have you seen your child this week?" As discussed below, my proposal does not rely on the law's legal enforcement mechanisms, but on its ability to trigger community enforcement and self-sanctioning. First, however, I will address some alternatives to joint legal custody and discuss why joint legal custody is the better approach.

\section{Why Not Joint Physical Custody?}

Many fathers reject joint legal custody in favor of joint physical custody, arguing that the former does not provide them greater access to their children because the children still live with the mother in most cases, and the father has only visitation. Thus, they argue, joint legal custody is, in effect, no different from sole maternal custody with paternal visitation, and the law should recognize fathers' equal role in their children's upbringing by awarding them joint physical custody.

Czapanskiy have criticized the law's failure to support or sanction fathers' nurturing or lack thereof, noting how the law does not sanction fathers for failure to spend time with their children even after they have agreed to do so in a custody and visitation agreement. Czapanskiy, supra note 115, at 1437-38 (advocating holding parents who do not comply with visitation orders in contempt); Dowd, supra note 89, at 526 ("The model of fatherhood embedded in law is dominantly biological and economic. . . . support for the nurturing aspect of fatherhood is very limited, hidden, and indirect.")

${ }^{372}$ See supra note 65 (discussing sanctions imposed on parents who did not pay child support).

${ }^{373}$ Scott, supra note 29, at 1949 n.129.

${ }^{374}$ CAL. FAM. CODE $\$ 3028$ (a)-(b) (West 2004) (allowing the court to order financial compensation for periods when a parent fails to assume caretaking responsibility, while limiting compensation to reasonable expenses incurred consequently by or on behalf of the child); COLO. REV. STAT. § 14-10-129.5(4) (2003) (requiring courts to order parents failing to exercise court-ordered parenting time to pay attorney's fees, court costs, etc., for the complying parent bringing an action against them). 
Social scientists have found that fathers with joint physical custody are very involved in their children's upbringing and tend to share close relationships with them. ${ }^{375}$ Some studies have also found that a dual residence arrangement has a positive impact on children's adjustment. ${ }^{376}$ Joint physical custody may be conducive to a better relationship between the child and the parent who would likely have had residential custody because of the decreased likelihood of the "burnout" phenomenon that occurs when one parent has almost exclusive responsibility for the child's day-to-day care. ${ }^{377}$ Given all these benefits of joint physical custody, why do I instead recommend joint legal custody?

First, joint physical custody is difficult to implement logistically. Living in two places is hard for many children. Many young children need the stability of one home and one set of rules while older children, although better able to juggle schedules, may resent having to move from home to home. A dual residence arrangement requires the parents' geographical proximity so that the children can attend the same school and activities, and have the same set of friends. After divorce, one parent may not want to live in the same neighborhood as the other parent or may not be able to find or afford a home that is in close proximity to the other parent's home. Maintenance of dual residences is costly, since the children would require two sets of everything (toys, clothes, computers, etc.) and each parent would need a home that is large enough to accommodate the children for long periods of time. For most divorcing couples, supporting two households is a struggle. For this reason, in part, the majority of couples who attempt joint physical custody are upper middle class or wealthier, and thus, have the means to maintain separate homes. ${ }^{378}$ Further, although there are not many studies on joint physical custody, two have "suggest[ed] that children in joint physical custody [arrangements]

\footnotetext{
375 See, e.g., Lee, supra note 138, at 675-76 (describing a study finding more paternal involvement among fathers sharing physical custody).

${ }^{376}$ See Eleanor E. Maccoby et al., Postdivorce Roles of Mothers and Fathers in the Lives of Their Children, 7 J. FAM. PSYCHOL. 24, 25-27, 34 (1993) (discussing a four-year longitudinal study of children under age sixteen at the time of divorce, finding that child satisfaction was greatest when the children had dual residences, although the benefits were contingent on the parents' low-conflict relationship). In one study of 820 college students whose parents had been divorced for approximately ten years, seventy percent reported that the best living arrangement would have been "equal time" with their fathers and nearly twenty percent selected "substantial overnights" with their fathers. Fabricius \& Hall, supra note 297, at 454 fig.4.

${ }^{377}$ Lee, supra note 138 , at 675-76.

378 Cohen, supra note 18 , at 45 .
} 
were no better adjusted than children" in families where the mother has physical custody. ${ }^{379}$ Thus, the empirical evidence does not yet support joint physical custody in the majority of cases.

Second, and more importantly, the law is effective in influencing social norms where there already is some consensus in the community that the norm the legal rule is seeking to establish is legitimate and

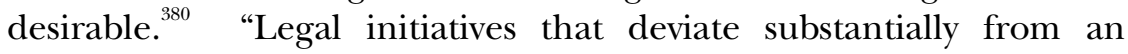
emerging community consensus ... are unlikely to have substantial impact on the target norm." ${ }^{381}$ Although most Americans agree that paternal involvement benefits children, most are still opposed to joint physical custody and many who believe it is desirable find themselves unable to implement a dual residence arrangement successfully. In California, possibly the state most supportive of joint custody, the majority of couples who shared physical custody reverted to a traditional maternal residence (or paternal residence in some cases) within two years of divorce. ${ }^{382}$ Even with a joint physical custody decree, most parents reverted to maternal residential custody after a short period of time. How can the law enforce joint physical custody if both parents ignore the decree and, in effect, choose maternal residential custody? As Professor Scott has observed, "reforms favoring joint physical custody failed to influence behavior because they were apparently inconsistent with the private preferences of parents regarding custodial arrangements." ${ }^{\text {"83 }}$ Thus, so long as parents and society in general are opposed to joint physical custody, it is unlikely that the law can create a norm of shared physical custody. In contrast, Americans believe that both parents should share decision-making authority and both should spend significant periods of time with their children, thereby making it more likely that society will accept a presumption of joint legal custody. ${ }^{384}$

${ }^{379}$ Gallagher, supra note 129 , at 178 (internal quotation marks omitted); FURSTENBERG \& CHERLIN, supra note 23, at 75.

${ }^{380}$ See Scott, supra note 29, at 1969 ("[T] he success of a legal reform may depend on the coincidence between the legal prescription and community opinion.”).

${ }^{381} I d$.

382 MACCOBY \& MNOOKIN, supra note 13, at 113 fig.5.3, 275-76 (noting that only twenty percent of couples even attempt joint physical custody).

${ }^{383}$ Scott, supra note 29, at 1969 n.190.

384 Another approach to custody is the American Law Institute's Principles of the Law of Family Dissolution which bases parents' access to the children after divorce on the proportion of time they each devoted to the children and child rearing during the marriage. AM. LAW INST., supra note $334, \S 2.08$ (a). Thus, if the children spent eighty percent of their time with their mother during the marriage and only twenty percent with their father, the father would be entitled to spend one quarter as much time with 


\section{B. Creating a Norm of Nurturing Fatherhood}

The legal reforms and sanctions discussed above may be sufficient to motivate some nonresidential parents to remain actively involved in their children's lives. ${ }^{385}$ Some parents, however, will not comply with court orders, and legal enforcement of parental responsibilities is costly and not necessarily desirable. Courts do not have the resources to hold a hearing or order community service every time a nonresidential parent fails to pick up the children for the weekend. Rather than relying on legal enforcement of these reforms and sanctions to

the children as the mother. This rule is based on the notion that the parents' time with the children after divorce will approximate their time with them during the marriage. $I d$. at $\$ 2.08 \mathrm{cmt}$. a, at 180 ; see also Lucy S. McGough, Starting Over: The Heuristics of Family Relocation Decision Making, 77 ST. JOHN's L. REV. 291, 314 (2003) (discussing this approximation principle); Scott, supra note 202, at 617 (proposing that custody be based on the approximation rule-this proposal was subsequently adopted by the ALI). The rule "assumes that the division of past caretaking functions correlates well with other factors associated with the child's best interests, such as the quality of each parent's emotional attachment to the child [and] the parents' respective parenting abilities.” AM. LAW INST., supra, at $§ 2.08 \mathrm{cmt}$. b.

In theory, the approximation principle will encourage fathers who are still married to spend more time with their children because it will increase the amount of time they will be able to spend with them if and when the marriage ends. Assuming that happily married fathers think about what would happen in the event their marriage fails, the approximation principle may encourage married fathers to be more involved. However, it will have no effect on fathers who no longer reside with their children. Indeed, it will discourage those fathers who were not significantly involved in their children's upbringing during the marriage from seeking to be involved after divorce. Thus, the approximation principle not only fails to signal to fathers that they are important but limits access for those fathers who worked long hours while their spouses assumed the traditional role of primary caregiver. It further "denies both spouses, except by mutual agreement, the right to change roles when the marriage terminates [and] also refuses to recognize that comparative time spent may not adequately reflect each parent's emotional relationship with the child." NAT'L INTERDISCIPLINARY Colloquium on Child Custody, Legal and Mental Health Perspectives on ChILd Custody LAW: A DESKBoOK FOR Judges $§ 2: 3$, at 13 (1998). Fathers frequently argue that they should not be penalized post-divorce merely because they were primary economic providers during the marriage rather than primary caretakers. The approximation rule, in effect, would reward the primary caretaker even though the breadwinner's financial contributions made it possible for her to dedicate more time to child rearing. By failing to consider a parent's financial contributions to the child's upbringing, the approximation principle further ignores that families' allocation of caregiving responsibilities during the marriage are not necessarily indicative of the arrangement they would have chosen had they contemplated divorce when they first had children. For these reasons, I reject the approximation principle in favor of a presumption of joint legal custody with significant parenting time and child-rearing responsibilities for both parents.

${ }_{385}$ See Cooter, Do Good Laws Make Good Citizens?, supra note 367, at 1598-1600 (noting that many citizens obey the law out of respect for the law itself). 
motivate nonresidential parents to remain actively involved in their children's lives, my goal is that they will lead to the creation of social norms of involved fatherhood and stimulate community enforcement and self-sanctioning. If paternal involvement were mandatory, even with minimal legal enforcement, eventually neighbors, colleagues, relatives, and friends would informally enforce paternal contact by expressing disapproval of fathers who do not participate in their children's upbringing. In time, some fathers might internalize this norm of involved fatherhood and experience guilt or shame if they neglected to parent their children. The desire to avoid societal disapproval, along with internalization of the norm of involved fatherhood, might lead fathers to better parent their children.

According to Richard McAdams's esteem theory of norms, social norms arise because individuals want others to think highly of them and thus seek the approval of colleagues, neighbors, family members, and even strangers. ${ }^{386}$ In other words, most individuals follow social norms, at least initially, because they do not want to be perceived as deviant. ${ }^{387}$ But how do we know when a certain behavior has become a social norm such that nonconformance will give rise to societal disapproval? Richard McAdams has argued that a norm arises if (1) there is a consensus that certain behavior is desirable; (2) there is some risk that others will detect a person's failure to engage in the desired behavior; and (3) the relevant community is aware of this consensus and of the risk of detection. ${ }^{388}$ Applying these factors, I argue that the law can create a social norm of paternal involvement.

First, the law can create a consensus that paternal involvement is desirable and that people disapprove of paternal disengagement. Whether the law will influence a norm depends on whether the law is consistent with community expectations about the behavior the norm requires. ${ }^{389}$ There already is significant support for the notion that paternal involvement is desirable. ${ }^{390}$ Indeed, there is a consensus that married fathers should be more involved in their children's upbring-

${ }^{386}$ McAdams, supra note 30, at 355-57. Even individuals who may not intrinsically value what other people think of them may still "value approval . . . instrumentally because it helps to achieve other ends." McAdams, supra note 37, at 343.

${ }^{387}$ McAdams, supra note 30, at 356.

${ }^{388}$ Id. at 358.

${ }^{389}$ Scott, supra note 29, at 1927.

390 See supra Part II.C (showing that paternal involvement, or lack thereof, can affect a child's emotional and educational progress). 
ing. ${ }^{391}$ The premise behind joint custody laws is the acknowledgment that children need both parents. The trend toward a presumption or preference of joint legal custody is further evidence that Americans recognize that both parents should be involved in their children's upbringing even after the parents' marriage dissolves. ${ }^{392}$ Thus, it is unlikely that society would be opposed to increasing divorced fathers' involvement, especially in light of the empirical evidence suggesting that paternal involvement benefits children, mothers, fathers, and society in general. Many people, however, may not be aware of the societal consensus that children benefit from a relationship with both parents and that society disapproves of fathers who abandon their children after divorce. ${ }^{393}$ This is where the law can help. When it is unclear whether a community approves or disapproves of a certain behavior, "a legislative proclamation can publicize [the approval pattern] and create a norm.", ${ }^{394}$ As shown below, statutes requiring that nonresidential parents see their children would signal that paternal involvement is necessary and desirable and that the community disapproves of parents who do not nurture their children. ${ }^{395}$

Politicians seriously consider their constituents' positions on proposed legislation because their likelihood of reelection, or election to a higher office, depends on constituents' satisfaction with their voting records. Thus, the legislature's "decision to enact or not to enact legislation, as reported through the media, declares to the public a winning side," thereby providing evidence of a consensus. ${ }^{396}$ According to Professor McAdams hypothetical analysis, before the law required that citizens clean up after their dogs or that citizens not smoke in public buildings, people assumed that public disapproval of these activities was not very high. However, once legislators passed pooper-scooper and no-smoking laws, people started to believe that public disapproval

${ }^{391}$ See supra Introduction (highlighting the current cultural perception of the modern father as an involved and attentive parent).

392 See supra notes 111-21, 133 and accompanying text (noting that many Americans believe that children benefit from contact with both parents). A consensus can exist even if a majority of the population is indifferent so long as a significant minority shares the same view. McAdams, supra note 30, at 358.

${ }^{393}$ See Leo, supra note 105, at 22 (noting that fathers are not aware of their importance to their children).

${ }^{394}$ McAdams, supra note 37, at 371.

395 Cf. McAdams, supra note 30, at 402-03 (describing the role of legislation in signaling a consensus).

${ }^{396}$ Id. at 402; see also McAdams, supra note 37, at 340 (arguing that individuals' beliefs about what other people approve or disapprove of are often wrong, but statutes accurately indicate to the public of what people approve and disapprove). 
of these behaviors was high. ${ }^{397}$ Here, the enactment of laws mandating paternal contact would publicize the consensus-of public opinionthat paternal contact is desirable and that most individuals disapprove of paternal disengagement. So long as "the other two conditions for norm formation are present (inherent risk of detection and awareness of that risk), [legislation] publicizing that most people disapprove of a certain behavior[, e.g., paternal disengagement,] will create a new expected cost to acting in violation of the (previously unknown) consensus" in favor of paternal involvement. ${ }^{398}$

Highly publicized judicial opinions often reflect public opinion and thus, similar to legislation, may also signal a consensus. ${ }^{399}$ When the media publicizes a $\$ 50,000$ award for child support arrears, an order to "boot" a car, or a judge's suspension of a lawyer's or doctor's professional license for failure to pay child support, it signals "the underlying attitudes of [the] community," ${ }^{" 400}$ a general consensus that parents must support their children financially. Similarly, if the media were to publicize a judicial opinion sanctioning a parent for failure to comply with a visitation order, citing social science studies finding that children benefit from a relationship with both parents after divorce, it would signal to the public a consensus in favor of paternal involvement.

Second, the risk that others will detect a nonresidential parent's failure to see his children is significant. The mother will know if the father has failed to assume parental responsibilities and spend time with the child. There is clearly a risk that she will inform others of the father's undesirable behavior. The father's colleagues, neighbors, and family members, as well as his children's teachers, may all be able to detect whether he is spending time with his children. One relative who discovers that the father is not parenting his child may tell other relatives, increasing the number of people who will likely express disapproval of the father's behavior. In addition, public penalties-such as community service, "booting" vehicles, or posting the names of parents who have not seen their children as agreed in the parenting plan on government agencies' websites, or in family courts or other public buildings-increase the risk that the community will discover when a father has failed to parent his children.

${ }^{397}$ McAdams, supra note 37, at 365.

${ }^{398}$ McAdams, supra note 30, at 402.

399 See generally McAdams, supra note 37, at 341, 378 (arguing that "judicial decisions are positively correlated with popular attitudes").

${ }^{400}$ Id. at 340. 
Third, the relevant community, including nonresidential fathers, would be aware of the consensus in favor of paternal involvement because the law, by making parenting mandatory, will have publicized this consensus. Further, the media is likely to publicize legislation and/or judicial opinions requiring that nonresidential parents remain involved in their children's upbringing. One can only imagine the attention that talk shows, newspapers, magazines, and websites would devote to laws "forcing fatherhood." The relevant community will undoubtedly be aware of the risk that others will detect when a nonresidential parents has failed to see his child. Thus, the three conditions for creation of a norm of paternal involvement are present.

Individuals choose to engage in certain acts based on the intrinsic value of the act (e.g., the value of maintaining contact with my children), ${ }^{401}$ the reputational costs of that choice (e.g., the community's expressed disapproval of my failure to nurture my children), and its effects on one's self-conception (e.g., wondering if I will feel that I am a bad parent if I do not spend time with my children). ${ }^{402}$ Most fathers want to continue their relationship with their children after divorce; ${ }^{403}$ thus, the intrinsic value of spending time with their children may already be somewhat high. The obstacles discussed in Part III, however, may make it costly (both emotionally and financially) for nonresidential parents to remain engaged, especially when there are few social costs to paternal disengagement. As stated above, individuals follow social norms, at least initially, because they want to gain others' esteem or avoid the loss thereof. ${ }^{404}$ Thus, the community enforces social norms and prevents potential norm violators from defecting by the threat of disapproval. ${ }^{405}$ When a person violates a norm, public disap-

${ }^{401}$ The intrinsic value of the choice is influenced by the social norm. See Sunstein, supra note 32, at 915 ("[P] erceptions of intrinsic value will be often a function of social norms.”). For example, although I may not consider sending my child to school to be more intrinsically valuable than having her help with the family business, the fear of societal disapproval may cause me to perceive my child's education as more valuable than I otherwise would were there no stigma attached to not sending children to school.

${ }^{402}$ See id. (concluding that the intrinsic value of an option, the reputational benefit or cost of an option, and the effects on one's self-conception all influence individuals' choices).

${ }^{403}$ Supra text accompanying note 156.

${ }^{404}$ See supra notes 386-87 and accompanying text (explaining that people follow social norms in order to gain the approval of others and to avoid being thought of as deviant).

${ }^{405}$ Id. 
proval may cause embarrassment and even shame. ${ }^{406}$ The negative feelings brought about as a result of violating a norm can be intense, and the social consequences of those feelings (wanting to hide or disappear in order to avoid the disapproval) can be significant. Their anticipation can be even worse. ${ }^{407}$ A norm of paternal involvement would dramatically increase the reputational costs of not parenting one's children after divorce because neighbors, colleagues, friends, and family members who would now be aware of the societal norm of paternal involvement might express disapproval of a parent who fails to see his child. ${ }^{408}$ The father who desires their esteem or wishes to avoid the loss thereof will likely weigh the costs of these informal sanctions in his determination to parent or not parent his children. ${ }^{409}$ In addition, community members might express disapproval not only of the disengaged father, but also of his family members and close friends. ${ }^{410}$ To illustrate, we might expect people to express disapproval of a woman who dates a man who does not support his children financially. Similarly, once the law signals that most people disapprove of parents who refuse to be involved in their children's upbringing, we might expect people to stigmatize the disengaged father's parents or a woman who dates or marries him. The disengaged father's parents or his new wife who value their own reputations would have

${ }^{406}$ Sunstein, supra note 39, at 2029-30.

${ }^{407}$ See id. at 2030 (noting that "the most effective use of norms is ex ante," and that "[t]he expectation of shame ... is usually enough to produce compliance"). Thus, even if no one expresses disapproval, a parent may change his behavior in its anticipation.

${ }^{408}$ Although one might expect that some individuals would refuse or fail to express disapproval of a parent who does not see his child, individuals who do shun the disengaged father may withhold esteem from those people who do not censure the disengaged father. See McAdams, supra note 30, at 372 (arguing that a primary norm may produce a secondary enforcement norm that arises when individuals censure those who fail to censure primary norm violators). Thus, the fear that they will lose esteem if they do not express disapproval of disengaged fathers may lead more people to censure such fathers.

409 "Individuals vary in the extent to which they are ready to tolerate the reputational costs of challenging existing norms. For each individual, this will depend on how much the norm distorts private preferences, the level of anticipated sanctions for violation, and the value of acting honestly on preferences." Scott, supra note 29, at 1970. Thus, fathers who do not wish to see their children and do not care what community members think of them may not be influenced by the threat of societal disapproval, but these are likely to be few.

${ }^{410}$ Kahan, supra note 28, at $643 \mathrm{n} .215$ (" [S] haming penalties ... are likely to have a spillover effect, stigmatizing not just offenders but their family members and friends."). 
an interest in ensuring that the father complies with the norm of involved fatherhood and may encourage him to parent his children.

In addition to the external sanctions the community imposes for nonconformance with norms, many individuals internalize norms and experience guilt when they fail to comply with them, even if others do not detect the violation. ${ }^{411}$ According to Professor Cooter's internalization theory, norms develop when the community unanimously endorses certain behavior (e.g., spending time with one's children) and convinces "some members of the community to internalize the obligation, and to inculcate it in the young." ${ }^{412}$ The internalization of norms is so powerful that it may affect private thoughts, changing not only individuals' external behavior but also what they honestly believe is acceptable or unacceptable. ${ }^{413}$

Norm theorists such as Professors Cooter and McAdams have focused on individuals' compliance with recycling, littering, smoking, and pooper-scooper laws, even when no one from their community is likely to detect noncompliance, to illustrate how individuals have internalized these norms. ${ }^{414}$ I believe parents are more likely to experience shame and guilt if they violate parenting norms than if they violate littering or recycling norms. All parents want to be perceived and want to perceive themselves as good parents. Most parents have internalized the role of "parent" and experience guilt if they believe they have failed to be good parents. ${ }^{415}$ Although what is required to

411 See McAdams, supra note 30, at 381 ("After internalization, there is yet another cost to violating a norm: guilt. The individual feels psychological discomfort whether or not others detect her violation."); see also id. at 408 ("Even absent external, informal enforcement, the law can elicit internal enforcement."); Richard E. Scott, The Limits of Behavioral Theories of Law and Social Norms, 86 VA. L. REV. 1603, 1604 (2000) (arguing that pooper-scooper and no-smoking-in-public-places laws "can have self-sanctioning (or third order) effects to the extent that citizens internalize the legal rule and are deterred by the prospect of guilt").

${ }^{412}$ Cooter, supra note 28, at 224; see Robert D. Cooter, Decentralized Law for a Complex Economy: The Structural Approach to Adjudicating the New Law Merchant, 144 U. PA. L. REV. 1643, 1666 (1996) (noting that "a consensus will convince some members of the community to internalize the norm and to ingrain it in the young"). But see McAdams, supra 30, at 380 (arguing that unanimity is not necessary-"a simple consensus may be sufficient" to create a norm).

${ }^{413}$ See Sunstein, supra note 32, at 929 (noting that because of norms that discourage pollution, smoking, or sexual harassment, individuals "may come in their private thoughts to see such things as unacceptable").

${ }_{414}$ Cooter, supra note 38, at 6-7 (pooper-scooper laws); Cooter, supra note 412, at 1661 (smoking); McAdams, supra note 30, at 350, 382-83 (recycling and littering).

${ }^{415}$ McAdams, supra note 30, at 408 ("[M]any [parents] feel guilt if they believe they fail to be a 'good' mother or father."); see also Nancy Samalin \& Steve Bennett, What Makes You Feel Guilty?, PARENTS, Oct. 1999, at 99, 99 (finding that parents frequently 
be a good parent can mean different things to different people, sometimes the law tells parents what good parents do-for example, requiring child safety car seats, school attendance, child vaccinations, etc. Thus, "legal rules can clarify and announce the specific behavioral expectations embodied in social norms" such as good parenting. ${ }^{416}$ To use Professor McAdams's illustration, by requiring parents to use child safety devices, the law expresses a consensus that failure to do so is "contrary to minimally acceptable parental behavior." 117 Most parents accept the apparently informed judgment of legislators (in conjunction with child safety experts) about what child safety requires and feel that they are not good parents if they fail to comply with the norm. ${ }^{418}$ They would experience guilt if they do not comply with the law.

Similarly, I argue that by passing legislation requiring fathers to spend time with their children, the law would express a consensus that failure to do so indicates bad parenting. Although the majority of Americans agree that children are better off when they maintain a relationship with both parents after divorce, there are currently no rules to guide mothers and fathers in determining how a nonresidential father should behave. ${ }^{419}$ The law can and should clarify behavioral expectations of post-divorce fatherhood. ${ }^{420}$ Indeed, the law has been successful in clarifying parenting norms in other contexts. To use Professor Scott's example, before the enactment of compulsory school attendance laws, there were no rules setting forth exactly how good parents educate their children. Consequently, parents interpreted the good parent norm "according to their own values and exigencies." Some parents sent their children to school while others "educated" their children informally at home or on the farm. For example, my grandfather took my father out of school when he was only twelve years old. He believed that by teaching his son how to run the farm (the family business) he was teaching him how to be a productive citizen. The enactment of compulsory attendance laws, however, sig-

\footnotetext{
experience guilt about almost every aspect of parenting, which in turn motivates them to change their behavior).

${ }^{416}$ Scott, supra note 29 , at 1926.

${ }^{417}$ McAdams, supra note 30, at 408.

${ }^{418}$ See id. ("If one accepts that being a good person requires something, then it is difficult to resist the (apparently) informed judgment of others about what child safety requires....")

${ }^{419}$ See supra Part II.

${ }^{420}$ Cf. Scott, supra note 29, at 1926 (arguing that "legal regulation can play a role in shaping normative behavior in marriage")

${ }^{421}$ Id. at 1927.
} 
naled to parents, including my grandfather who kept the younger children in school, that compliance with the good-parent norm required that he provide his children with formal schooling. In addition to the threat of legal sanction, parents had to contend with the disapproval of their neighbors if they did not behave as good parents and send their children to school. "Eventually, parents internalized the [compulsory attendance laws] as establishing a baseline of what good parenting required," feeling "guilty if they violated the norm" and disapproving of parents who failed to comply. ${ }^{422}$

Similarly, bright-line rules such as a requirement that parents share joint legal custody and spend a significant amount of time with their children would "clarify precisely" the behavior that is required from divorced nonresidential parents. ${ }^{423}$ It would be difficult for parents to refute the judgment of legislators, who, with the assistance of child-development experts, have concluded that paternal involvement is beneficial to children. Thus, the law would express a consensus as to what good parents do and some fathers who have internalized the norm would experience guilt if they did not nurture their children. Further, as Professor Waldeck has argued, "the existence of the norm might even lead a person to exaggerate the personal guilt or loss of external esteem that might result from failure to comply with the norm." involved in their children's upbringing, the norm itself may cause fathers to "misapprehend[] the actual consequences of compliance or noncompliance with what they perceive to be the norm., ${ }^{425}$ In other words, even if the community's disapproval and the guilt that parents will experience are moderate, once a norm of involved fatherhood exists and the law defines the behavior required by the norm, fathers are likely to exaggerate the potential sanctions and comply with the norm even if the sanctions are unlikely to be severe. This misapprehension of the actual consequences of not complying with the norm makes it more likely that fathers will parent their children after divorce.

${ }^{422} I d$.

${ }^{423}$ See id. at 1926-27 (noting generally that "[1] egal regulation functions to particularize the broader behavioral standards embodied in social norms").

${ }^{424}$ Waldeck, supra note 30 , at 464 .

${ }^{425} I d$. at 465. 


\section{CONCLUSION}

The law walks a dangerous line when it attempts to regulate human behavior. As commentators have noted, sometimes such attempts backfire and push norms in the opposite direction. ${ }^{426}$ Further, without empirical evidence, social norms theorists are relying on intuitive guesses to predict human behavior. This proposal is open to those criticisms. Without empirical evidence, it is impossible to know whether requiring fathers to parent their children will lead to greater involvement and fewer cases of paternal abandonment. In an age of individualism, neighbors might not care all that much whether a father has seen his children this week, and even if they do, they might not care enough to express disapproval. Even if neighbors publicly express disapproval of disengaged fathers, some fathers might not care what others think and might never internalize the norm of paternal involvement. In the same manner that some fathers who do not pay child support have convinced themselves that they are good parents and that their reasons for not paying support are valid despite the stigma attached to deadbeat fathers, ${ }^{427}$ some fathers may convince themselves that they have valid reasons for not seeing their children.

But some might not. Many Americans recycle, clean up after their dogs, and pay their taxes, even though the risk of legal sanction is minimal, because they fear public disapproval and have internalized these legal rules. For the same reasons, some fathers might be motivated to parent their children-because they do not wish to be perceived as emotional deadbeats and because they have internalized the legal rule of paternal involvement, believing that good parents nurture their children even if they no longer reside with them. The law should attempt to keep these fathers engaged not only for the benefits to their children, but for the potential benefits to society overall.

\footnotetext{
${ }^{426}$ See Sunstein, supra note 32, at 919 (noting how "legal efforts to inculcate social norms" may be counterproductive and efforts to "stigmatize certain acts may have the opposite effect").

${ }^{427}$ Fathers' reasons may include: the amount is too high, the money is not going to the children, the mother is using the money to finance her extravagant lifestyle, etc.
} 